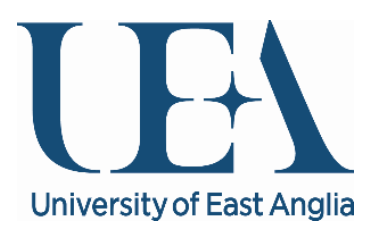

\title{
C'CP
}

\section{Revisiting the Regulatory State: A Multidisciplinary Review Establishing a New Research Agenda}

\author{
David Deller \\ Centre for Competition Policy \\ University of East Anglia \\ Francesca Vantaggiato \\ Centre for Competition Policy and \\ School of Politics, Philosophy, Language and Communication Studies \\ University of East Anglia \\ CCP Working Paper 14-9
}

\begin{abstract}
This paper provides a comprehensive literature review of the 'Regulatory State' through the lens of utility regulation. The review is multidisciplinary with it bringing together the insights available from the political science, economics, legal and management science literatures. It is clear that while the term 'Regulatory State' is essentially missing from the economics literature a vast array of economics papers provide valuable insights for debates about the Regulatory State within political science. In addition to reviewing the existing literature, the paper identifies opportunities for future research. The literature is grouped into five topics: (i) Consumers, (ii) Courts, (iii) Ideas, Experts and Expertise, (iv) Governance and (v) Assessing Regulator Performance. Apart from (iv), we believe all of these areas have been under-researched in relative terms. In particular, a key finding is that compared to the information available on Public Utility Commissioners in US States, very little information has been collated on the background, characteristics and careers of individual utility regulators working within Europe.
\end{abstract}

\section{Contact Details:}

David Deller d.deller@uea.ac.uk

The authors wish to acknowledge the contribution of the ESRC who supported their research through Centre for Competition Policy funding (ref: RES-578-28-0002). 


\title{
Revisiting the Regulatory State: A Multidisciplinary Review Establishing a New Research Agenda
}

\author{
David Deller ${ }^{1}$ and Francesca Vantaggiato \\ Centre for Competition Policy, University of East Anglia, UK
}

\begin{abstract}
This paper provides a comprehensive literature review of the 'Regulatory State' through the lens of utility regulation. The review is multidisciplinary with it bringing together the insights available from the political science, economics, legal and management science literatures. It is clear that while the term 'Regulatory State' is essentially missing from the economics literature a vast array of economics papers provide valuable insights for debates about the Regulatory State within political science. In addition to reviewing the existing literature, the paper identifies opportunities for future research. The literature is grouped into five topics: (i) Consumers, (ii) Courts, (iii) Ideas, Experts and Expertise, (iv) Governance and (v) Assessing Regulator Performance. Apart from (iv), we believe all of these areas have been under-researched in relative terms. In particular, a key finding is that compared to the information available on Public Utility Commissioners in US States, very little information has been collated on the background, characteristics and careers of individual utility regulators working within Europe.
\end{abstract}

Acknowledgements: This work is the result of extensive and prolonged discussions with a team of researchers at the ESRC Centre for Competition Policy (CCP). We would like to particularly thank: Hussein Kassim, Morten Hviid, Catherine Waddams, Michael Harker, Chris Hanretty, Despoina Mantzari and Elizabeth Errington for their many suggestions and ideas. We would also like to thank Christel Koop and other seminar participants at the ECPR Standing Group on Regulatory Governance's $5^{\text {th }}$ Bienial Conference in Barcelona for their additional comments.

\section{Introduction}

Since the 1980s, the Regulatory State in Europe has grown and established itself as a significant presence within the political and economic landscape. The purpose of this paper is two-fold: to provide a representative, though not exhaustive, literature review on the concept of the 'Regulatory State' through the lens of utility regulation, and to identify gaps in this literature where further research is warranted.

A central aim of this literature review is to exchange insights about the Regulatory State across the political science, economics, legal and management science disciplines. The diversity of the papers discussed in this review highlights the value of increased inter-disciplinary dialogue if a comprehensive view of the Regulatory State is to be obtained. Beyond fostering inter-disciplinarity, a number of other factors suggest it is an opportune moment to revisit the concept of the Regulatory State in Europe. Above all, it is now 30 years since the institutions of the Regulatory State started to emerge in Europe. Sufficient time has elapsed for a significant quantity of econometric evidence on the performance of regulated utility industries to have accumulated which can be used to form overarching conclusions about the Regulatory State's performance. As part of this assessment, there is the potential to address areas which have so far received comparatively little attention in discussions of the Regulatory State,

\footnotetext{
${ }^{1}$ Corresponding author: david.deller@uea.ac.uk
} 
but which are crucial to forming a holistic picture of this form of governance, such as the positions of consumers, the courts and expertise. Finally, the information available on the characteristics of utility regulators in the European setting is limited and largely uncollated. This stands in contrast to the data available on utility regulators in US States. To further the accountability of the Regulatory State in Europe it is crucial that steps are taken to address this information shortfall.

While numerous articles and papers about regulation and public policy refer to the term 'Regulatory State', those focused exclusively on the Regulatory State are relatively few, representing a compact sub-literature within the wider literature on regulation. Significantly, while the Regulatory State as a term is almost completely absent from the economics literature, there are a multitude of papers within this discipline that are directly relevant to understanding and evaluating the Regulatory State.

Defining the Regulatory State is difficult because it encompasses a series of phenomena and because it takes different forms in different parts of the world. We focus on the Regulatory State as it has manifested itself in Europe and, hence, define the Regulatory State according to the European context. The Regulatory State in Europe is based on the acknowledgement that, since the 1970s, increased international competition and deepening economic integration within the EU has been associated with a reduced role for the interventionist type of state. This retreat from the interventionist state challenged governments as it represented a profound shift in the values, priorities and expectations of the role of states within Europe (McGowan and Wallace, 1996). In parallel to this retreat from interventionism there was an increase in the regulatory role of European states. Regulatory rulemaking therefore can be seen as "replacing taxing and spending" (Majone, 1997) as the preferred mode of government influence over the economy. Or going further, the Regulatory State is a state "which attaches relatively more importance to processes of regulation than to other means of policymaking" (McGowan and Wallace, 1996). A further, crucial, part of the Regulatory State's meaning in Europe (and elsewhere) concerns the rise of specific institutions to operationalise the Regulatory State: the regulatory agencies.

While the definition of Regulatory State above is well suited to the EU experience, it fits less neatly with the experience of the other prototypical regulatory state, the USA. Moreover, the definition above has been challenged by scholars who do not view the demise of the "taxing and spending era" of European (and other) governments as being so clear cut (Levi-Faur, 2013; Pflieger, 2014). Nevertheless, the view that the Regulatory State represents a fundamental break with previous (welfare-based) modes of public policy is central to what is meant in Europe by the expression 'Regulatory State'.

In the European political science literature the notion of the Regulatory State is associated with particular authors. The growth of a Regulatory State in the European context is first acknowledged, by Majone $(1994,1996,1997)$ who seeks to provide a comprehensive theory of why, and how, it arose. Given that 20 years have elapsed since Majone's original work and the Regulatory State has not diminished in size or scope, it seems appropriate to revisit the Regulatory State. To make the analysis manageable and to enable a stronger narrative, we focus on the Regulatory State as it has developed with regard to economic regulators for the network industries (energy, telecoms, water, rail). There are two additional reasons for the focus on network industries. Firstly, the creation of independent regulatory agencies in these industries was at the leading edge of the Regulatory State's growth in the UK and, indeed, in Europe. Secondly, from an economic perspective, these industries have a common 
and coherent justification for regulation: each industry contains a physical 'network' which has the properties of a natural monopoly ${ }^{2}$. This focus in no way diminishes the importance of the Regulatory State that has developed in the social sphere (e.g. health and safety and pharmaceuticals regulation etc.) and the potential for further work in this latter area.

Despite the justification of natural monopoly, some economists did not envisage the Regulatory State, in the form of utility regulators, being permanent or, at least, did not believe it would continue to exist in its current 'expansive' form. Rather, the notion of introducing competition where possible seemed to imply that, after privatisation and liberalisation, regulation of potentially competitive markets would be temporary (Littlechild, 1983; Baron, 1991; Weisman, 2006). Only in narrowly defined natural monopolies would regulation continue, and here it would be light. In reality, the role of regulation and regulators has not really diminished in the post-privatisation/liberalisation landscape. Instead, sector regulators seem to be being given additional responsibilities and coming under pressure to incorporate concepts beyond narrow economic considerations into their decisions, such as environmental sustainability (Yarrow, 1991; Joskow, 1996b; Crew and Kleindorfer, 2012) and social obligations to protect the vulnerable (Valletti et al, 2002; Sharratt et al, 2007). This divergence from the initial expectations of some provides another reason to revisit the Regulatory State.

The primary focus of the political science literature on the Regulatory State has been on the twin topics of independence and accountability. The recurrence of these themes in the literature highlights how substantial a change the rise of the Regulatory State has represented for the polities of Europe, previously used to significant government intervention in the economy and on a 'providing' role for the state. However, even in Majone's original work, it is apparent that there are other topics, beyond independence and accountability, that can be fruitfully explored and, indeed, must be explored to gain a complete picture of the Regulatory State.

There appears to be room for further research in five key areas:

(i) Consumers - How do those who are supposed to benefit from regulation actually engage with it? How have consumers been conceived; and how does this link to the conception of vulnerable consumers?

(ii) Courts - To what extent are courts and regulators alternatives? To what extent have courts influenced regulations and the development of the Regulatory State?

(iii) Ideas, Experts and Expertise - How have ideas spread between regulators? How do regulators access expertise to implement these ideas? How do the career options of 'expert' regulators influence their decisions?

(iv) Governance - How are effective regulators structured and monitored? Do sector specific regulators have a future? How important are co-operation and regulatory networks in improving regulatory outcomes?

(v) Assessing Regulator Performance - How should the performance of regulators be assessed? Taken as a whole, what does the empirical evidence say about the performance of network industries in the UK and Europe over the 30 years during which the Regulatory State has developed?

\footnotetext{
${ }^{2}$ A natural monopoly is a situation where it is economically efficient for a single firm to supply the market. For example, if two railway lines were built between London and Norwich instead of one, it is unlikely that the benefits of competition would outweigh the extra cost of building the second railway line.
} 
The article is organised so that each of the following sections corresponds to one of these five topics with a conclusion in Section 8. The one exception to this pattern concerns Governance which is split across Sections 5 and 6 . Section 5 covers issues of independence and accountability, while section 6 covers supranational regulation, regulatory networks, the overlap between sector regulation and competition policy, and the merits of creating multi-sector regulators. Before moving on to explore these topics, the rest of the introduction provides further background on the Regulatory State as a concept and the literature explicitly considering the Regulatory State.

\section{The Development of the Regulatory State as a Concept}

Further developing the pioneering work of Majone $(1994,1996,1997)$, Moran $(2002,2004)$ focuses on the emergence of the Regulatory State in Britain and how this changed the political culture by replacing "club government" with a formal, contractual approach to governance. Furthermore, Lodge $(2008,2010)$ considers the interplay of the Regulatory State at the European and member state levels and the importance of network industries in the development of the European Regulatory State. Expansion of the Regulatory State to additional countries and sectors is highlighted by Levi-Faur (Jordana et al, 2011), who then expands the Regulatory State theme by developing the concept of Regulatory Capitalism (Levi-Faur, 2005) and the Single European Regulatory Space (Levi-Faur, 2011). The idea of Regulatory Capitalism is also explored by Braithwaite (2005) who sees regulatory growth of the state being fuelled by the rapid rise of corporate, rather than state, governance (Braithwaite, 2006). All of these authors deal explicitly with the notion of the Regulatory State, be it to describe it, to explain it, or to propose ways to improve its functioning.

Three of the authors above have written substantial literature reviews: Moran (2002), Lodge (2008) and Levi-Faur (2013). Moran (2002) focuses on the political science and, especially, the legal literature in a comparative perspective between the US and Europe; while Lodge (2008) focuses on how the Regulatory State at the European level feeds downs to the member states. Levi-Faur (2013) distinguishes between an old and a new State, following Moran (2002), and views the Regulatory State as existing alongside the welfare state. According to Levi-Faur, the old State obtained its authority from its monopoly over the use of coercion, whereas the new 'Regulatory' State is characterised by authority based on a monopoly over rule-making, monitoring and enforcement in the context of the decentralisation of regulatory power.

In the European context, other authors beyond Majone, Moran, Lodge, Levi-Faur and Braithwaite have also provided important, although less systematic contributions, to the Regulatory State literature. Loughlin and Scott (1997) were among the first to suggest that Britain had transformed into a Regulatory State. The other papers, such as McGowan and Wallace (1996), focus on the EU as a Regulatory State or compare the most significant Regulatory States (Yeung, 2010) ${ }^{3}$. The papers focusing on the EU provide a range of insights: Caporaso (1996) views the EU state as a post-modern, rather than Westphalian or 'just' regulatory state; Eberlein and Grande (2005) investigate the role of regulatory networks in the EU's Regulatory State; Radaelli and De Francesco (2007) highlight Regulatory Impact Assessments (RIAs); while Radaelli and Meuwese (2012) explore the constitutional dimension of the EU's transformation into a Regulatory State.

\footnotetext{
${ }^{3}$ Yeung compares the Regulatory States in Britain, the US and the EU.
} 
In this article, while the focus is on the Regulatory State in the UK and EU, the US literature is discussed where relevant. ${ }^{4}$ Indeed, the concept of a Regulatory State was first conceived within the US setting. Also, in contrast to the Regulatory States in Europe, the US Regulatory State is associated with the imposition of "big government" (Lodge, 2008), particularly at the federal level, and increased state intervention rather than liberalisation and deregulation. A similarity that can be drawn between the US and European literatures is that the Regulatory State is linked strongly to supra-national (or suprastate) institutions. Interestingly, while in Europe the Regulatory State is discussed both at the supranational and national levels, in the US the term is rarely associated with exploration of state level regulation by Public Utility Commissions (PUCS).

While discussions of utility regulation in the US began in the $1920 s^{5}$, the first academic contribution which truly analyses the 'Regulatory State' is Anderson (1962) who emphasises the bureaucratic expansion of US agencies. Later, Seidman and Gilmour (1986) describe the Regulatory State to explain the shift "from the positive to the regulatory state" in the context of outsourcing and privatisation. It is in the 1980s when the literature on the US's Regulatory State really emerges. For example, see Risk (1984), De Long (1986), Shapiro and Levy (1987) and Sunstein (1987, 1989a, 1989b, 1990). Generally these papers focus on the legal basis and structure of the Regulatory State. In these contributions, network industries generally do not feature, instead, analysis is performed for federal level agencies which receive oversight from the President (or Congress).

A range of factors has led to the development of a Regulatory State at the EU level, with the most influential being: (i) the desire to achieve a European single market; (ii) the primacy of EU law in matters of competition; and (iii) the shared competence with Member States for issues such as the integration of infrastructure systems. The major obstacle to the widespread acceptance of a European Regulatory State is its perceived lack of legitimacy (Majone, 1999). In Majone's analysis, the EU became a Regulatory State itself due to two forces. Firstly, the European Commission (EC) was created as the first supra-national regulator; member states delegated to the EC regulatory authority for the management of the single market to achieve stronger mutual commitment to the process. Secondly, the EC was endowed with a small budget by member states and was granted no direct powers of taxation to deprive the EC of the means to act autonomously. Given the lack of budgetary power, the easiest way for the EC to increase its policymaking reach was through regulation.

\section{Consumers}

\section{Consumer Representation}

Consumers are intended to be the ultimate beneficiaries of competition, and where competition does not function effectively, regulation. However, there has been debate about how the voice of consumers should be incorporated into the regulatory process and the dangers of a 'regulator knows best' model. The importance of effective public participation when developing regulatory policy had attention drawn to it by the concept of 'Responsive Regulation' (Braithwaite and Ayres, 1992; Braithwaite, 2011).

\footnotetext{
${ }^{4}$ The UK, US and EU are seen as archetypal paradigms of the Regulatory State, however, papers have extended the concept to the Global South (Dubash and Morgan, 2013) and Asia (Jayasuriya, 2001).

${ }^{5}$ Brown (1924) and Bauer (1927) explore issues of judicial review and rate of return calculations that would be familiar to utility regulators today.
} 
Various models of consumer input have been proposed including using consumer advocates, giving additional prominence/powers to consumer organisations or regulators stepping back from interactions between consumers and firms. However, before exploring each of these possibilities, it is worth remembering that consumers are also citizens (Lunt and Livingstone, 2011). ${ }^{6}$ Even without a direct input into the regulatory process, consumers can have an indirect impact on the regulatory landscape through their political power. At the most basic level, legislatures set the mandates of regulators and may determine the importance regulators attach to consumer versus producer interests (Baron, 1988; Hanretty, 2013).

A crucial issue is the desirability of having markets and industries subjected to the political pressures of consumers. For example, price cycles coinciding with election cycles have been found for regulated industries in Brazil (Moita and Paiva, 2013). While in EU member states the boards of regulatory authorities are appointed via processes involving politicians, in some US states Public Utility Commissioners (PUCS) are directly elected. The variation between US states regarding whether regulators are elected or appointed, and its impact on regulatory outcomes, has been studied by a range of authors (Holburn and Spiller, 2002b; Kwoka, 2002; Besley and Coate, 2003; Hlasny, 2013). Predictably, these authors find that elected commissioners are associated with lower prices and outcomes that are less favourable for firms. Also, Berry (1979) finds that the saliency of regulation to consumers perceived to be 'missing out' under a particular regulatory regime, determines consumers' influence over PUCs. The notion of consumers as citizens also provides a link to the discourse on public service obligations (Heritier, 2001; 2002) and the accountability of regulators when they are unelected.

In the European context, Maier (1993) provides an early study of the institutions representing consumers in the EU. However, in political science studies relating to Europe, consumers tend to be analysed simply as a particular type of interest group, rather than being a group of distinct and primary significance. ${ }^{7}$ For example, see Greenwood (2011). In a similarly general vein, Pollack (1997) looks favourably on EU institutions as attractive venues for lobbying by diffuse interests (e.g. consumers, environmentalists and women) due to the EU's multi-level structure providing multiple points of access. However, despite this structure, Howarth (2008) explains that consumer interests have traditionally been poorly represented in EU policymaking, although, the situation is improving. The creation of a Consumer Protection Cooperation Network may be an example of this improving situation (Poncibo, 2012).

The early literature on consumer representation is from a US perspective. For example, Leflar and Rogol (1976) identify two factors that remain central to the success (or failure) of consumer representation: the resources available to consumer representatives and their accountability to consumers. Indeed, turning to the UK and EU, Dayagi-Epstein (2007) notes that simply granting consumer associations legal significance does not mean that they have the capability to play an effective role in the regulatory process. Similarly, the NAO (2004) criticises the UK's statutory consumer bodies for not understanding the needs of consumers sufficiently. The evidence certainly suggests that within Europe the processes and effectiveness of consumer representation vary by

\footnotetext{
${ }^{6}$ Reisch and Micklitz (2006) also highlight the multiple roles individuals might play in markets. As consumers start to self-generate electricity (e.g. from solar panels on household roofs), it may be necessary to consider 'prosumers' who share characteristics of both producers and consumers.

${ }^{7}$ The presence of the Journal of Consumer Policy and the Journal of Consumer Research suggests that in other disciplines consumers constitute a more clearly delineated group.
} 
industry and member state (Simmonds, 2002; DTI/HM Treasury, 2004; Ogus et al, 2006; Bellantuono and Boffa, 2007; Sanz et al, 2011). ${ }^{8}$

At one level, since the promotion of consumer interests is a primary consideration (at least implicitly) for regulators (Littlechild, 1994; Ogden, 1997; Vass, 2003; Waddams Price, 2004; Field, 2007) the need for additional consumer representation may appear open to debate. Regulators may commission research themselves to understand consumers' needs and their satisfaction levels, for example, see Ipsos-Mori (2012). Also, consumers' needs and the quality of service they receive may be embedded into formal assessments of regulatees' performance through particular performance measures involving consumer feedback (Ogden, 1997; Chau, 2002; Prendergast, 2002; Sappington, 2005; Growitsch et al, 2010).

However, if regulators actually pursue their own objectives, considering regulation as a two-level principal-agent problem where consumers oversee a regulator and, in turn, a regulator oversees a firm, may be more appropriate (Demski and Sappington, 1987). One question is the weight regulators place on consumers' views when taking practical decisions. For example, Gormley et al (1983) found that PUCs held views closer to those of utility executives than those of consumer advocates. Similarly, regulators inevitably place less weight on consumer interests than consumers themselves since a regulator's key task is to be independent of any one interest and also regulators may be required to balance competing interests (Vass, 2003). However, if regulators place insufficient weight on consumer interests they risk consumers questioning the legitimacy of the whole regulatory system (Mumford and Gray, 2010; Franceys and Gerlach, 2011; Decker, 2013).

To take account of consumers' interests, regulators need mechanisms to hear consumers' voices. In the US in the 1970s proxy advocates were created that, while funded by government, were independent of regulators (Gormley, 1981; Holburn and Bergh, 2006; Stein, 2011). Berry (1984) notes that opening proceedings to the public and having consumer representatives intervene in regulatory proceedings can alter regulatory policy by changing regulators' incentives. An alternative is for consumers to be represented by their own organisations. The choice is then the extent to which these consumer organisations are backed by the state and have formal recognition in the regulatory process (NAO, 2004; Page and Bakker 2005). It is here, in understanding how consumer organisations operate and interact with regulators that political science could offer new insights.

A more radical alternative is for greater power to be given to consumers via mechanisms that bypass the regulator. Indeed, a possible organising theme for the literature on consumers is the juxtaposition of consumer empowerment with consumer protection (see the subsection on vulnerable consumers). For example, private class actions can be allowed in the courts (Schaefer, 2000; Vogelsang et al, 2007; Cafaggi and Micklitz; 2009) or the buyer power of consumers might be increased via consumer aggregation schemes (Colton, 2006; Littlechild, 2008; Laufer et al, 2013). For both mechanisms there is debate as to their advantages and disadvantages. That consumer empowerment might involve consumers collaborating as citizens is further developed by Ramsay (2006).

\footnotetext{
${ }^{8}$ Additionally, Franceys and Gerlach (2011) compare consumer participation in the UK's water industry with that in less developed countries.
} 
The ability and desirability of a regulator removing themselves from the customer-regulatee interaction perhaps illustrates the biggest practical difference between consumers and customers ${ }^{9}$ in the Regulatory State. While regulators were often created specifically to protect consumers, given their lack of understanding and power in the marketplace, for large corporate customers these justifications for regulatory protection are lacking. A number of papers highlight the apparent success of corporate customers reaching negotiated settlements with utilities (Civil Aviation Authority, 2005; Doucet and Littlechild, 2006; Littlechild, 2007; Doucet and Littlechild, 2009; Glachant et al, 2008). In the model of negotiated settlements, regulators only provide a basic framework in which the negotiations take place and a fall-back position should things go wrong. The mechanisms for a regulator to reduce their involvement in the consumer-regulatee relationship, without completely disappearing, could be explored further. Investigations of new regulatory approaches, such as the introduction of consumer challenge panels by OFWAT in the UK's water sector and OFGEM in the UK's energy sector, could be valuable.

Also, the distinction between consumers and customers may be important in assessing the performance of the Regulatory State. It seems plausible that the benefits of competition and the liberalisation of wholesale markets may be clearer for corporate customers (Littlechild, 1988a; Newbery and Pollitt, 1997) than for domestic consumers. ${ }^{1011}$ Indeed, the power of industrial customers as a particular interest group may be important in determining the outcome of regulation. For example, Henisz and Zelner (2006) note corporate customers' ability to discipline political actors. Further investigation of the balance between the interests of customers and consumers in the Regulatory State seems warranted.

\section{Assumptions Concerning Consumer Behaviour}

Consumers not only have a role in steering the objectives of regulation; how their behaviour is conceived determines the extent to which regulation is required and the form that regulation should take. Despite liberalisation and the rise of the Regulatory State often being justified to electorates on the grounds of improved outcomes for consumers, it has been argued that initially little explicit thought was given to the part consumers would play in enabling effective competition (Ogden and Anderson, 1995; Defeuilly, 2009; Xavier and Ypsilanti, 2010, Clifton et al, 2011). There is now acceptance that if liberalised markets are to persist and succeed, understanding consumer behaviour is critical (Waterson, 2003; McFadden, 2006). Indeed, reaching policy objectives may be reliant on particular behaviours by consumers and the plausibility of these desired behaviours occurring may be open to question (Lavrijssen, 2014).

In the economics literature there has been considerable effort to understand the behaviour of consumers in regulated industries, particularly with regard to consumers' decisions to switch suppliers

\footnotetext{
${ }^{9}$ It is important to recognise the distinction between customers and consumers. Consumers are the individual people who consume goods and services. Customers are the wider set of purchasers that includes companies buying goods and services from regulated industries to produce other goods and services. Consumers are a subgroup of a regulated firm's customers.

${ }^{10}$ Of course, a chain of corporate customers will ultimately produce a good or service for consumers. Hence, even if the outcomes of regulated industries are skewed towards benefitting corporate customers, indirectly, consumers of final goods and services should benefit from the lower prices/improved service being provided by the regulated industries to corporate customers.

${ }^{11}$ Studies that focus solely on consumer welfare changes following liberalisation and deregulation include McGowan (2000) and Gupta (2013).
} 
and the costs of switching. For example, there is a long line of investigations into consumers' switching decisions in energy markets in the UK (Waddams Price and Bennett, 1999; Giulietti et al, 2005; Sitzia et al, 2012; Flores and Waddams Price, 2013; Waddams Price et al, 2013; Giulietti et al, 2014), Europe (Juliusson et al, 2007; Ek and Soderholm, 2008) and the US (Hortascu et al, 2012; Kleit et al, 2012). While in telecoms markets there have been studies investigating the impact of regulatory intervention, in the form of number portability, to enable easier switching between suppliers (Shi et al, 2006; Park, 2011).

Much of the concern that exists in network industries relates to consumers' ability to understand offers in telecoms markets (European Regulators Group, 2009; ACMA, 2011a; 2011b) and the combination of low consumer satisfaction with low switching rates in energy markets (Brennan, 2007; Von der Fehr and Vegard Hansen, 2010; European Commission, 2010; Ipsos-Mori, 2012). At the heart of this debate about consumers is the extent of consumers' rationality; are consumers fully rational as in the stereotype of the economics discourse or do consumers behave according to various psychological biases. For example, Wilson and Waddams Price (2010) present evidence that few consumers in the UK electricity market select deals that maximise their monetary savings. Even if consumers are rational, there is the additional question of whether they possess the information required to make optimal decisions. Also, the rationality of consumers is crucial to determining whether moves to further enhance the role of the market are likely to generate benefits. For instance, the impact of real-time electricity pricing will depend on how consumers interpret and respond to electricity prices (Bushnell and Mansur, 2005; Wolak, 2006; 2011a; 2011c; Leautier, 2012). Similarly, in telecoms there is debate as to whether consumers have a bias for flat rate tariffs (Miravete, 2003; Lambrecht and Skiera, 2006).

In the past decade there has been an explosion of interest from competition and regulatory authorities regarding the implications of behavioural economics for their work (Mulholland, 2007; Ofcom, 2010; Bennett et al, 2010; Ciriolo, 2011; Huck and Zhou, 2011; Ofgem, 2011; Erta, 2013). This emerging interest in behavioural economics demonstrates the potential overlaps between the five themes identified in the introduction. While behavioural economics is intimately concerned with consumer behaviour, it also provides a case study of how new ideas emerge and diffuse through the regulatory space.

Since behavioural economics tends to focus on the biases or 'mistakes' of consumers it often is associated with increased regulatory intervention. While this is true, there are concerns about how to apply the lessons of behavioural economics to actual markets. Some of this debate over 'intervention' has an ideological feel, however, there are legitimate concerns about how to identify 'behavioural' versus 'rational' consumers (Rizzo and Whitman, 2009a; Oxera, 2010; Cseres, 2012). In particular, there is the open question of how remedies can be designed which do not penalise non-behavioural consumers or create other detrimental effects (Littlechild, 2012). One way to mitigate these risks is to run pilots and conduct testing as a particular intervention is rolled out (Better Regulation Executive/National Consumers Council, 2007; Office of Fair Trading, 2009; Bennett, 2010; Sunstein, 2011). Another, more fundamental, concern is whether regulators themselves can avoid behavioural biases when making policy decisions (Tasic, 2011).

\section{Vulnerable Consumers and Consumer Protection}


Central to the debate on vulnerable consumers is how to define a 'vulnerable' consumer and the extent of protections required to offset the identified vulnerability. A small number of papers consider the politics of energy affordability and access to other utility services (Waddams Price and Hancock, 1998; Graham, 2006; Reisch and Micklitz, 2006; Bartl 2010). However, the focus on vulnerability is most closely linked to evidence on the differing engagement of particular groups with markets which has led to concerns that the gains associated with retail competition have not been shared equally (Hausman and Sidak, 2004; Clifton et al, 2011). Some work has been conducted on whether traditional definitions of vulnerability, such as old age and disability, are correlated with behavioural biases (Lunn and Lyons, 2010). However, when defining vulnerability, economic regulators may step beyond their traditional role to make decisions based on distributional issues (Oxera, 2010) which are better suited to a political arena. Not only may distributional decisions be inappropriate for unelected technocrats (Majone, 1996), but the economics literature generally considers market interventions to be an inefficient way of achieving distributional objectives (Borenstein, 2012; Borenstein and Davis, 2012).

Linked to the question of regulatory overreach is how the notion of consumer protection fits with that of competition. For example, Vickers (2004) notes that, until recently, economics had not really engaged with questions of consumer policy. This lack of emphasis probably related to a traditional emphasis on the power of consumer sovereignty and the benefits of increased choice. In broad terms, Averitt and Lande (1997) and Muris (2003) see consumer protection as protecting consumers from acts and practices that hinder their choices in the marketplace. Stuyck (2005), instead, believes that EU competition law provides an effective shelter for consumer interests. What is true is that, giving consumers increased protection, may mean they take less care in markets and, hence, make poorer decisions (Armstrong, 2008; FSA, 2008). As such, holding consumers responsible for their decisions is important.

The other risk of consumer protection remedies is that they may distort the competitive market (Littlechild, 2006; Armstrong, 2008; Wolak, 2011b) with universal service obligations (Valletti et al, 2002) representing a particularly strong intervention. ${ }^{12}$ Indeed, it has been suggested that greater competition itself may resolve consumer protection issues (Vickers, 2004; Gauduel and Sugden, 2012). The potential conflict between public service values, economic efficiency and consumer choice within the Regulatory State is a theme picked up by Prosser (2005a). Prosser's analysis contrasts the approaches of France and the UK to regulation (Prosser, 2005b) and, more generally, explores the links between public services and social solidarity (Prosser, 2006) together with the social limits of privatisation (Prosser, 1995).

Regardless of the merits of particular consumer protection measures and the definition of vulnerability, it is clear that this area is a contested space and at the heart of the overall debate regarding paternalism versus individual sovereignty in regulation. In this debate, consumer and industry groups tend to lobby along predictable lines (Ofgem, 2006; FSA, 2008). However, Sharratt et al (2007) notes instances from the UK energy market where firms differentiated themselves by their commitment to implementing social obligations.

\section{Courts}

\footnotetext{
12 Not only may universal service obligations introduce large distortions, they may be used by EU member states to retain some control over social policies in arenas where changes imposed by the EU single market affect particular groups (Harker et al, 2013).
} 
Regulation involves setting rules and drafting provisions to back those rules with enforcement measures; therefore, any comprehensive discussion of regulation is intertwined with the legal system. Both the US and the European literatures on the role of law in the Regulatory State are large. This is particularly so in the case of the US; in part because the PUCs in US states were created as courts. Hence, as early as Brown (1924) the role of courts versus commissions in public utility regulation was being discussed together with the appropriate extent of judicial review.

In the US legal literature on regulation, the main themes, beyond administrative law and judicial review, are the characteristics of US adversarial legalism (Kagan, 2001) and the role of the Supreme Court. In the legal literature on regulation in the EU there is an equivalent focus on the European Court of Justice (ECJ), although, the discussion focuses on whether the ECJ is an engine for integration or an agent of the member states. Other topics discussed in the European legal literature are the extent to which the EU regulatory landscape is becoming an adversarial system like the US (Kelemen, 2011) and the use of EU competition law as an instrument for EU institutions to expand their reach into regulated sectors. ${ }^{13}$

\section{Courts as part of the Institutional Environment}

The role of courts in regulation is not simply as a direct actor or reviewing body; institutional economics suggests courts form an important element of a country's institutional endowment. The strength of courts and the nature of the legal system will influence both the economic institutions and regulation which actually exist and, arguably, the form of economic institutions and regulation which is optimal (Larouche, 2006; Bellantuono, 2010). For example, the distinction between common law and civil law may influence the overall level of intervention within an economy; common law's function as a mechanism for private dispute resolution is seen to favour free markets (Gual and Trillas, 2006; La Porta et al, 2008).

In the discussion of countries' institutional endowments it is possible to view courts and regulators as alternatives and there is debate regarding the merits of each. This literature begins with consideration of safety regulation versus tort law (Shavell, 1984; Rose-Ackerman, 1991). In essence the desirability of each institution is determined along two dimensions: whether ex-ante or ex-post enforcement is desirable and whether individual or collective enforcement is most likely to succeed. Along similar lines, Shleifer $(2005,2010)$ places courts and regulation on a continuum of institutions from free markets to state ownership. It is argued that the Regulatory State began to grow in the US in the early $20^{\text {th }}$ century due to increases in the power, wealth and damage of corporations which overwhelmed the capabilities of the courts at the time (Glaeser and Shleifer, 2003). In this institutional literature the Chicago school's faith in courts is criticised and the potential for regulation to deliver superior outcomes is highlighted (Glaeser et al, 2001; Shleifer, 2005; 2010).

An important part of the debate about courts' role is whether they can overcome issues of regulatory capture and to what extent they are themselves subject to capture. There is the potential for courts, when reviewing decisions, to alter decisions that have been 'captured' (Helland and Klick, 2012). However, there is no reason why courts themselves cannot be captured or act in a self-interested manner (Elhauge, 1991; Posner, 1993; Glaeser and Shleifer, 2003; McCown, 2009). Indeed, a growing

\footnotetext{
${ }^{13}$ The potential overlaps between competition policy/law and regulation are discussed further in Section 7.
} 
realisation that courts may be captured by particular interests is seen as having shifted power back to regulatory agencies (Merrill, 1997; Glaeser and Shleifer, 2003).

The other issue that potentially limits the desirability of generalist courts is their ability to handle complex economic arguments. It has been shown that complex cases are more likely to result in appeals and that performance can be improved by providing judges with economics training (Kovacic, 1994; Baye and Wright, 2011). In the UK, one might consider whether the availability of a specialist court, the Competition Appeal Tribunal, has reduced the deficit in expertise (at least with regard to appeals) and, hence, has led to superior performance.

\section{Courts as Shapers and Reviewers of Regulation}

The most common discussion of courts within the regulatory process concerns their position as a reviewer of regulatory decisions and as a venue for appealing decisions. However, it is worth recognising that courts may be creators of regulation or at least significantly shape the form of regulation that is implemented (Popelier, 2012). The legal decisions made by courts can have a fundamental influence on subsequent regulatory activity (Kovacic, 2002). Also, as noted in Section 2 , by allowing aggregate litigation and private enforcement courts may provide an alternative venue for 'regulatory' decisions. Indeed, Ramello (2012) argues that class actions can enable 'regulatory innovation' by allowing entrepreneurial lawyers to highlight new areas of harm to which courts devise solutions. However, others are less sanguine about the ability of courts to fulfil this role (Schaefer, 2000; Viscusi, 2002) since there is no guarantee that the incentives for private litigation will lead to decisions maximising social welfare or even the optimal quantity of litigation (Shavell, 1997).

The traditional view of the courts as a reviewer of regulatory decisions means there are strong links to the literatures on administrative law and judicial review. In an early work, Brown (1924) concludes that if PUC decisions are reviewed or appealed, this should be only on procedural grounds rather than on a case's underlying merits. Brown argues that if the decisions of PUCs were to be re-assessed on their merits, it would undermine the very reason for creating PUCS, namely, having regulatory decisions made by a body of specialist experts. Also central to the discussion is the possibility that courts apply administrative law which may be designed to facilitate a degree of political control over agencies, as the creation of the 1946 Administrative Procedure Act (APA) in the USA clearly demonstrates (McCubbins et al, 1987; McCubbins et al, 1999).

While several observers (Majone, 1996; Geradin, 2004a) have argued in favour of drafting a 'European APA' for regulators, it must be noted that the APA itself only applies to regulatory agencies at the federal level. The APA does not apply to the PUCs, the state-level utility regulators. This is significant given the lack of supra-national regulatory agencies at the EU level. Nonetheless, most US States have equipped themselves with administrative codes covering the procedures of administrative agencies at the state level. The existence of the APA, state level administrative codes and the advocacy for European equivalents emphasises the importance attached to the oversight and control of regulatory bodies. Much of the analysis on the control and oversight of regulators focuses on requirements concerning the process of decision making; in Europe, so far, considerable attention has been given to two instruments which been widely adopted in the US: cost-benefit analysis and Regulatory Impact Assessments (RIAs). 
The structure of decision making can shift the balance of power away from regulatory agencies and back to political principals (Spiller and Tiller, 1997; Duprat, 2012). In the other direction, Eskridge and Ferejohn (1992) consider how US Supreme Court decisions in the 1980s limited Congress' ability to overrule agency decisions. Furthermore, both regulatory bodies and the courts themselves can make strategic choices about the decision making instruments they use to limit review at higher levels (Tiller and Spiller, 1999).

The discussion has a US focus due to the less developed nature of administrative law in the EU. It is argued that the EU faces issues similar to those facing US federal administrative law 50 years ago (Meuwese et al, 2009). The longer history of the Regulatory State and administrative law in the US means there are papers considering the relative positions of regulators, the courts and politicians through time. For example, Merrill (1997) suggests that in the 1970s power flowed to courts as they were seen as a possible solution to regulatory capture, but as pessimism about this function increased power flowed back to the agencies and confidence increased in the effectiveness of utility regulation (Kovacic, 1995). A key part of this movement was the introduction of the Chevron test, requiring courts to defer to agencies' interpretations of statutes when their meaning is unclear (Bressman, 2000; Miles and Sunstein, 2006). However, Miles and Sunstein (2006) find that court decisions regarding regulation still appear to show political policy preferences with conservative judges less likely to support agency decisions.

The way in which US courts have assessed regulatory decisions has also changed. For example, Shapiro (1988) highlights a growing emphasis on ensuring the 'right' decision is made from a technical or rational standpoint. Similarly, Bressman (2000) notes a shift from an emphasis on the venue of a decision to the process and quality of decision making. ${ }^{14}$ Equivalent analysis of the ebbs and flows of judicial influence in the Regulatory State within the UK would appear valuable. In particular, it seems sensible to consider the extent to which the changing balance of power between regulators and courts has resulted from conscious institutional design at the national and EU levels. In the broader European context, it might be desirable for studies explicitly considering the appropriate roles for courts and regulators and the position of utility regulation within the law, akin to the studies of Brown (1924) and Robinson (1928) for the US. Scott (1998) makes an important step in this direction by analysing the juridification of regulatory relations in the UK's utilities during the late 1990s.

The process of judicial review and its impact has been studied by a range of political science and legal authors (Schwarze, 1992; Black et al, 1998; Hertogh and Halliday, 2004; Turk, 2009). A central issue is the availability (or lack) of judicial review in different contexts. For example, in the EU, Larouche and De Vissier (2006) are concerned by the lack of judicial review for the soft-law instruments ${ }^{15}$ commonly used by the EC, while Cengiz (2011) worries about courts' abilities to overcome asymmetries of information when reviewing the EC's competition powers. Turning to the US, Biber (2008) argues reviews of agency inaction are as warranted as those of agency action, although Supreme Court decisions imply courts should defer to agencies' resource allocation decisions. However, there are cautions to viewing judicial review as the primary or sole mechanism to hold agencies to account,

\footnotetext{
${ }^{14}$ Also, this evaluation of the regulatory process and the quality of decision making suggests that court judgements could be used as evidence to assess the performance of the Regulatory State.

${ }^{15}$ The potentially ambiguous relationship between the EC's soft law instruments, such as guidelines and notices, and the courts also has been explored by Stefan (2008) and Korkea-Aho (2012). They highlight the benefits to courts of soft-law initiatives with Stefan arguing that soft-law has supported hard-law enforcement, while Korkea-Aho suggests the Better Regulation initiative should provide courts with better information.
} 
instead, accountability is achieved through a complex network of public and private actors (Oliver et al, 2010; Bignami, 2011a).

\section{The Law as a Tool of Europe}

When discussing the interaction of courts and the Regulatory State in the European context it is important to recognise that national courts have to enforce EU law and, as such, they are mechanisms through which the EU's role within the regulatory space is increased. At a basic level, utility regulators must ensure that their actions comply with EU competition law (De Streel, 2003; Monti, 2008). Whether this dominance by EU competition law excessively constrains regulators has been discussed by Monti (2008), while other authors see the EU (over)extending competition law to achieve regulatory objectives (Temple-Lang, 2009; Tapia and Mantzari, 2013; Sadowska and Willems, 2013).

Also, EU law is seen as supporting the convergence of member states' legal practices and judicial review (Hilson, 2003; Essens et al, 2009; Larouche and Taton, 2011). Furthermore, Van Boetzelaer and Princen (2012) highlight the role European regulatory networks play in promoting the uniform implementation of EU law. Indeed, Hancher and Larouche (2010) suggest the EU's legal paradigm is changing with formal separations being replaced by integration where the competences of the EU and national regulatory authorities are blurred. Further to this, Kelemen (2011) argues that a more adversarial system, akin to the US, has replaced a flexible, but opaque, system of regulatory decision making that courts rarely challenged. While Kelemen $(2006,2011)$ affirms the Americanisation of the European legal style others either mildly (Kagan, 1997, 2006, 2007) or strongly (Levi-Faur, 2005) deny this development. Bignami (2011b) seeks to resolve this conflict and coins the expression "cooperative legalism". Bignami views European regulatory systems as converging, but not on American-style litigation. Instead, Bignami argues a common model of deterrence-based regulatory enforcement and industry self-regulation is being adopted. However, a comparison between member states of courts in relation to regulatory decision-making appears to be missing from the literature.

In the European arena a strand of research discusses the emergence of a 'European Administrative Space' (Olsen, 2003). Regarding the European Administrative Space, links are drawn between the supranational and national levels by Egeberg and Trondal (2009), while the development of the space over a decade is considered by Trondal and Peters (2013). It is also relevant to mention the emergence of global (or international) administrative law (Kingsbury et al, 2005; Stewart, 2005). Global administrative law is often tackled within the broader global governance discourse and it is sometimes openly longed for (Esty, 2006). The evolution of global administrative law, and that it has a life of its own, is discussed by Brake and Katzenstein (2013) with the fact that it is shaped by networks rather than by intergovernmentalism being emphasised by Slaughter and Zaring (2006). As with other aspects of the Regulatory State there is a development in the literature from acknowledging facts (the gradual formation of a layer of global administrative law) to assessing the transparency, accountability and legitimacy of this new governance layer (Kingsbury and Stewart, 2008; Donaldson and Kingsbury, 2013).

\section{Ideas, Experts and Expertise}


For particular individuals to possess expertise and be seen as experts there must be a set of ideas or technical knowledge for them to possess. In the Regulatory State, and as mentioned in Section 3, a key form of expertise is a knowledge of economics. ${ }^{16}$ Taking this role for economic knowledge as a given, the task for investigation becomes one of identifying how different economic ideas have developed, spread and come to influence the Regulatory State through time. As Section 2 highlights, the most recent set of ideas to come to the fore in regulation have been those of behavioural economics.

In many ways the analysis of ideas within the Regulatory State over the past 30 years can be broken into two elements: (i) discussion of the 'meta-ideas' of liberalisation, deregulation and New Public Management (NPM), and (ii) the various specific techniques which might lead to 'better' regulation.

\section{The Meta-Ideas of Liberalisation, Deregulation and New Public Management}

A key debate in the economics literature concerns the extent and permanence of regulatory interventions. Firstly, one might consider why deregulation occurred. Joskow (1996a) suggests that, at least in the electricity industry, liberalisation was driven by policymakers coming to view the costs of state owned vertically integrated monopolies as outweighing the benefits. For example, in the UK it is suggested that the increasing costs of state owned industries' investment plans led to privatisation (Yarrow, 1999; Green and Haskel, 2004). Indeed, rather than being a grand ideological concept the policy choices of the UK privatisation and liberalisation programmes can be seen as ad hoc and shorttermist (Kay, 1996; Littlechild, 2010). However, more importantly, the notion of 'deregulation' leading to reduced regulation that gradually fades away was already questioned by the mid-1990s (Armstrong et al, 1994). In practice, regulatory agencies have remained permanent suggesting that a better description of the process occurring in the 1980s and 1990s is 'regulatory reform' (Armstrong et al, 1994; Crew and Kleindorfer, 2002). The potential fragility of liberalisation when the underlying economics of particular industries favours heavily integrated enterprises has also been recognised (Joskow, 1996a; Newbery, 1997; Yarrow, 1999).

The debate concerning the relative merits of the market versus regulation does not exist in isolation from the public. Public support is needed for liberalisation to continue and to be effective (McFadden, 2006). As a result, a number of studies identify empirically the determinants of demand for regulation or liberalisation. One question for institutional economics is why the population in countries with ineffective and corrupt states tend to want more rather than less regulation. ${ }^{17}$ The suggested answer is that greater public distrust fuels the demand for regulation (Aghion et al, 2010; Pinotti, 2012). Regarding the initiation of pro-market reforms, studies have investigated the role of policymakers' backgrounds and the extent of democracy and corruption (Dreher et al, 2009; Erdogdu, 2013). Following their establishment, the continuation of market institutions may be threatened by the interventions of multilateral lenders and divergences from the policies/institutions of peer countries (Henisz et al, 2005). Turning to variations in privatisation/liberalisation across US states, links are made to the relative performance of regulated industries in different states and the political power of different groups (Lopez-de-Silanes et al, 1997; Guerriero, 2012; Hlasny; 2011). In particular, clean government laws, state limits on spending and pro-consumer politicians appeared to favour the implementation of pro-market reforms while strong unions delayed them. Within the EU, the differing

\footnotetext{
${ }^{16}$ Vogelsang (2003) provides an exploration of how economists and economic ideas have influenced pricing structures in telecoms.

${ }^{17}$ It should be noted that much of the data in these studies concerns less developed countries.
} 
pace of liberalisation in different member states can be used to proxy the extent to which national preferences frustrate the implementation of EU legislation (Humphreys and Padgett, 2006).

The final way to conceive the debate on liberalisation and the role for regulators is to consider changing regulatory objectives that might justify a continued or expanded role for regulatory agencies. For example, behavioural economics might justify an increased role for regulators in correcting the mistakes of consumers (Cseres, 2012). The potential for behavioural economics to provide novel solutions fits with growing concerns about the engagement of residential consumers in liberalised utility markets (European Regulators Group, 2009; European Commission, 2010; Ipsos-Mori, 2012). Whether behavioural economics offers actual benefits depends on perspective, with consumer groups calling for increased protections for vulnerable consumers (Ofgem, 2006) while other authors worry about the 'new paternalism' of behavioural economics (Rizzo and Whitman, 2009a; 2009b).

The other concepts favouring greater regulation, at least within the energy sector, are environmental concerns and security of supply. The increased importance given to these topics is highlighted by Yarrow (1991), Joskow (1996b) and Crew and Kleindorfer (2012). As the objectives of energy regulation have shifted, it has been noted that regulation designed to encourage cost minimisation might be ill-suited to encouraging large irreversible investments involving significant uncertainties (Helm, 2001; Spanjer, 2008). For the desired investments to occur, greater state intervention may be required, as is already being seen in the UK (Pflieger, 2014). For example, to promote energy conservation the UK government may become more involved in the consumption decisions of individual consumers than has been considered wise, or achievable, over the past 30 years (Jackson, 2005).

One question to ask is whether these changing objectives accurately reflect the changing interests of the UK population. For example, is consumer support for moves towards green energy sufficiently strong to accept sustained energy price rises? Linking the objectives and performance of regulators to the quantified views of consumers and citizens appears to have received little, if any, attention in the existing literature.

While the discussion above focuses on debates surrounding liberalisation and deregulation in the economics literature, there is the corresponding issue of how the state has responded to these developments. In the UK, the rise of the Regulatory State has been fuelled by the increasing privatisation of infrastructure industries. As privatisation is characteristic of neoliberalism, in the political sphere, the rise of the Regulatory State has often been associated with an emphasis on market freedom that is typical of neoliberal stances. The other fundamental characteristic of the Regulatory State, as understood in Europe, is the notion of decentralised (or fragmented) government. By combining support for free markets and decentralisation, New Public Management (NPM) represents a set of ideas often associated with the Regulatory State. Osborne and Gabler (1993) represents the most widely acknowledged compendium of NPM ideas, introducing the expression "steering, not rowing" to suggest that government should not directly run the economy, but rather steer economic and social actors to behave in an optimal fashion. This conception mirrors the change from a 'providing' to a 'regulatory' state introduced by Majone (1994). The formalisation of relationships previously hidden within politics, the "managerialization" of public servants and the explosion of performance assessment (Moran, 2002) to provide accountability are seen as other fundamental elements of NPM. RIAs are a key example of NPM ideas being implemented within the Regulatory State. 
A range of UK scholars have analysed NPM and its impacts on the UK state including Rhodes (1996), Dunleavy (1994) and Hood and Scott (1996); while Hood (1995) provides a cross-country analysis of NPM. Pollitt $(2000,2001)$ provides further detail on NPM and how it was translated to influence various countries' policies (Pollitt and Bouckaert, 2011). However, Christensen (2012) detects the beginning of a post-NPM phase, in which the focus has shifted from efficiency, specialisation, markets and private-sector management styles to inter-organisational coordination between multiple stakeholders.

The work of Christensen mirrors a trend in the literature to assess the extent to which the NPM/neoliberal paradigm has actually been translated into the practical workings of the Regulatory State. For instance, Lodge (2010) cautions against linking utility privatisation and the rise of regulation too strongly. While a link between privatisation and the Regulatory State exists in the UK, in Germany and New Zealand, regulation grew considerably with only very limited privatisation. A pattern of liberalisation without privatisation is the general theme for EU member states, particularly regarding network infrastructure. Lodge also underlines that regulatory authorities are not fixed institutions with set characteristics; instead, the features and scope of regulatory authorities depend on the political context in which they are created. This argument fits with Levi-Faur's (2006) view that there is not a single form of Regulatory State, but a series of national regulatory capitalisms. As with the more recent economics and policy literature, Lodge (2010) notes the increasing number and range of regulatory objectives. He puts this development down to the irreconcilability of three values that the Regulatory State purports to support: efficiency, equity and resilience.

Levi-Faur (2013) argues that a state is defined as regulatory when it uses the instruments of regulation (i.e. rules) to govern and claims a monopoly over the creation of these rules. The content of the rules can vary substantially between Regulatory States and does not need to follow classic neo-liberal tenets. Instead, the Regulatory State coexists with the welfare state and regulatory policy may even be used to achieve welfare objectives. Pflieger (2014) provides support for this argument from case studies of the electricity and rail sectors in the UK and Germany. The gradual movement of the Regulatory State concept away from being inherently neoliberal is significant. Further empirical analysis can only help to add clarity to the definition of the Regulatory State in its practical rather than theoretical form.

\section{Specific Regulatory Techniques}

Identifying the influence and spread of particular technical ideas between different regulators by using process-tracing methodologies appears valuable. However, before one can commence along this path the key technical ideas that might form the basis of such a study need to be identified. There are at least four technical ideas that could be investigated: (i) incentive regulation superseding rate of return regulation, (ii) benchmarking and yardstick competition, (iii) cost-benefit analysis and RIAs, and (iv) behavioural economics. RIAs have already received considerable attention in the academic literature (see Section 6) and the increasing emphasis on behavioural economics has been discussed in Section 2.

One of the major changes in regulatory practice associated with the growth of the UK's Regulatory State in the 1980s was the adoption of incentive regulation (particularly RPI-X) instead of the rate of return regulation widely used in the US. The literature on incentive regulation appears to go through a series of distinct phases. Firstly, there are papers defining incentive regulation as a new form of 
regulation and discussing its potential merits (Beesley and Littlechild, 1989; Vogelsang, 1989). Then a series of papers consider the application of incentive regulation and the factors that raise the likelihood of it replacing rate of return regulation (Donald and Sappington, 1995; 1997; Crew and Kleindorfer, 1996). Finally, papers highlight the practical problems of implementing incentive regulation such as the setting of price caps and the extensive information gathering required to do this (Bernstein and Sappington, 1999; Joskow, 2014). Other papers suggest that incentive regulation favours cost minimisation at the expense of encouraging large investments when compared to rate of return regulation (Blank and Mayo, 2009; Vogelsang, 2010). As a result, hybrid forms of regulation combining features of incentive regulation and rate of return regulation have been suggested as a potential way forward.

The notion of yardstick competition, or comparing the relative performance of different regulated firms, can be attributed to Shleifer (1985). Due to the benefits that such comparisons potentially provide, by the end of the 1990s best practice was being established regarding the use of benchmarking to support incentive regulation (Jamasb and Pollitt, 2000). However, since this point the literature has focussed on the practical difficulties of benchmarking (Dassler et al, 2006). For example, the concentration of industries within particular countries means that international comparisons are needed if benchmarking is to be effective (Jamasb and Pollitt, 2003; Estache et al, 2004). Other authors have highlighted that companies can 'game' or manipulate benchmarking to their advantage (Tangeras, 2002; Jamasb et al, 2003; 2004).

There are other technical ideas that might be possible to track. These concepts include: auctions to allocate scare resources/franchises (Salant, 2000); real-time electricity prices (as discussed in Section 2); the use of financial methods and modelling (Green et al, 2010); and changing accounting standards/valuation methods (Grout et al, 2012).

While the above techniques provide material to explore the spread of ideas and expertise there are already papers looking specifically at the mechanisms which diffuse ideas across the regulatory space. Often these papers emphasise the complex venues and networks through which regulatory ideas spread (Jordana and Levi-Faur, 2007; Brousseau and Glachant, 2011; Weiner, 2013). Also, the interplay between local and global forces is discussed with national regulatory styles coming under pressure from the regulatory approaches encouraged by peer countries and inter-governmental organisations (Zelner et al, 2009; Wiener, 2013). ${ }^{18}$

A final issue to consider regarding technical ideas is their point of creation as opposed to their diffusion. Sometimes ideas emerge from policymakers engaged with the regulatory process (such as RPI-X, see Littlechild, 1983), but many arise from the academic economics literature. One hopes that the academic publication system facilitates the critical assessment of ideas so that only the most robust are implemented as policy. However, a realisation is beginning to occur that academic economists, as well as practitioners, may be captured by special interests so that, at least in theory, the development of particular economic frameworks could be biased by vested interests (Zingales, 2013).

\section{Expertise, Regulator Resources and the Regulatory Process}

\footnotetext{
${ }^{18}$ Also, within economics, there is a literature using mathematical models to understand the theoretical properties of information transmission (for example, see Banerjee and Fudenberg, 2004; Acemoglu et al, 2011; Kawamura, 2011).
} 
How 'expertise' is conceived, and the level of its importance, is a major point of contrast between the political science and economics literatures. In the former, expertise is seen as key factor legitimising the delegation of decision making responsibilities from elected politicians to unelected regulators (Majone, 1997). The expertise of regulators is seen to guarantee that they will engage in impartial and reasonable decision-making. Majone (1997) recalls the early American literature, such as Fainsod (1940), who explained that federal regulatory agencies were needed due to Congressmens' lack of knowledge. The need for continued expert monitoring of important markets has been so widely acknowledged in the political science literature that the importance of expertise has almost been taken for granted and so has actually received relatively little direct attention. The lack of systematic assessments in the political science literature on how regulators use expertise, other than in relation to RIAs, is nevertheless surprising. One recent exception to this is Schrefler (2013) who investigates how economic knowledge has been used in decisions made by the UK's telecoms regulator.

In economics, the idea of regulators having particular expertise (defined as set of specialist skills) which justifies their existence is rare other than as an advantage over generalist courts (Glaeser and Shleifer, 2003; Shleifer, 2005; 2010; Baye and Wright, 2011). The economics literature tends to views experts as individuals with superior information rather than possessing a particular skill. Although, Demski and Sappington (1987) define an expert as someone who is uniquely qualified to obtain information and emphasises that expertise is costly to acquire and too costly to for it to be routinely communicated. A key issue in economics is whether experts truthfully reveal their information to the principal they are supposed to serve. In particular, economics focuses on the potential for those identified as 'experts' to pursue their own interests by altering decisions through the information they provide.

The canonical model of strategic communication from an informed 'expert' to an uninformed decision maker is provided by Crawford and Sobel (1982). Recent reviews of the large literature on strategic communication are provided by Sobel (2011) and Valsecchi (2013). In essence, if there are divergent interests between a party sending information and a decision maker, the sender cannot credibly communicate all their information to the decision maker. The difficulties of credibly communicating information provides an alternative reason for delegating decision making authority to experts with delegation avoiding the need for communication (Demski and Sappington, 1987; Dessein, 2002). However, delegation does not remove the problem of the expert having differing incentives to the original decisionmaker (Jensen and Meckling, 1995). Hence, the delegation decision involves trading off allocating a decision right to someone with superior information against the fact that they will take a decision which is more suited to themselves than the principal.

Since the creation of independent regulatory agencies involves delegation from politicians to 'expert' regulators, the strategic communication literature only has limited relevance to the relationship between these two groups. Where the strategic communication literature is more relevant is in understanding how regulatory agencies incorporate knowledge from outside bodies such as economic consultancies and how information flows internally within regulatory agencies. Regarding the latter issue, a particular problem emerges when the evaluation of a subordinate's performance contains a subjective element, since the subordinate can have an incentive to pander to a superior's existing opinions (Prendergast, 1993). 
The literature provides a range of insights for communication where strategic decisions are made about the information that is revealed. ${ }^{19}$ Firstly, there may be a trade-off between an expert's incentives for information acquisition and the truthful communication of this information (Dur and Swank, 2005; Gerardi and Yariv, 2008; Che and Kartik, 2009). If the expert has differing interests to the decision maker, it encourages the expert to invest in information, but a larger difference in interests makes it harder to communicate this information. Secondly, consulting multiple experts with differing interests or biases in opposite directions can help to reduce communication problems (Milgrom and Roberts, 1986; Dewatripont and Tirole, 1999; Krishna and Morgan, 2001; Gentzkow and Kamenica, 2011). Additional work investigates the type of experts (in terms of bias) that should be appointed to committees (for example, Li and Suen, 2004) together with whether, and how, multiple experts should be allowed to communicate with each other (Wolinsky, 2002; Roldan, 2013).

In the US political science literature, expertise fits into analysis of the trade-offs inherent in delegation to regulatory agencies. The loss of political control is balanced against regulatory discretion to allow the benefits of technical expertise to be realised (Epstein and O'Halloran, 1994). For example, Bawn (1995) highlights how administrative procedures for regulatory authorities not only influence their political responsiveness, but also the technical accuracy of their decisions. Where there is debate about experts within the political science literature it concerns their accountability. Regarding the EU's regulatory state, Radaelli (1999) questions whether an explicit choice of technocracy and expertise over politics is actually necessary. Radaelli argues that expertise needs to be made more accountable within an increasingly politicised EU.

These perspectives tie into the discourse on the transparency and democratic legitimacy (or lack of it) among communities of experts who influence policymaking. Turner (2001) highlights two key problems regarding experts and expertise: equality and neutrality. On the one hand, experts are privileged possessors of knowledge, which shields them from public scrutiny; but on the other hand, experts' work and opinions are highly regarded, which undermines the impartiality of the liberal democratic state over different beliefs and opinions. Similarly, Rayner (2003) explores how expert judgement is presented as objective and transparent, while being buffered from public scrutiny. Once again international networks are relevant, with epistemic communities developing to which politicians turn to for advice (Haas, 1992).

The debate over the democratic legitimacy of institutions made up of experts has also taken place in the context of discussions about the democratic nature of EU institutions. On this question, the literature is split with authors, like Majone $(1996,1997)$ and Moravcsik $(2002,2004)$, believing there is no democratic deficit; while others, like Follesdal and Hix (2006), believing there is a deficit. The same debate can be applied to regulatory authorities at the national level. Given the question marks over regulators' legitimacy, it was initially argued that regulatory authorities should focus on a narrow set of technical issues, while broader policy decisions should remain with elected politicians (Majone, 2006). The reality, however, is for economic regulators to decide on matters with direct consequences

\footnotetext{
${ }^{19}$ It is worth noting that papers on strategic communication are generally very abstract and highly theoretical with communication often involving a binary 'Yes/No' decision or a particular numerical value.
} 
for the distribution of welfare in society ${ }^{20}$ and to regulate sectors characterised by significant political salience.

While the economics literature investigates the type of individual that is desirable to appoint as a regulator and the incentives facing individual regulators ${ }^{21}$, there is far less discussion of the day-today activities of regulators ${ }^{22}$ and the resources available to them. This relative lack of literature probably reflects a lack of high quality data, although, this difficulty does not reduce the importance of this topic.

The lack of research (and potential lack of detailed data) on individual regulators, their career trajectories and regulatory agencies in Europe is perhaps the key finding of this review. This lack of research stands in contrast to a substantial empirical literature looking at the characteristics, behaviour and performance of PUCS at the state level in the US. Without comparably detailed data, and a probing academic literature, a key mechanism for holding the European Regulatory State, and the experts who run it, to account is missing.

That a regulatory authority has a legal mandate to monitor and intervene in a market is insufficient to ensure effective regulation. If a regulatory authority lacks resources, it may not be able to enforce its mandate. Indeed, increasing complexity and increasing the responsibilities of regulators may be a deliberate tactic employed by special interests to reduce the effectiveness of regulatory enforcement (Tanzi, 2011). The total quantity of resources available to regulatory agencies has been considered mainly in the context of less developed countries and the limited qualified individuals such countries can call upon (Stern, 2000; Pollitt and Stern, 2011). For the US, Viscusi et al (2005) provide detail on the headcount and budgets of federal regulatory agencies over a period of 40 years. In the UK the annual reports of the main economic regulators appear to provide a similar level of detail, although, a Europe wide audit and comparison of regulatory agency resources does not appear to exist. Investigating the relative numbers of economists, lawyers, accountants and generalist civil servants within regulatory agencies could quantify the extent and type of expertise that regulatory agencies possess.

Despite the lack of collated European data on regulator resources, the role of resources is discussed in more general terms. For example, Trillas (2010a) notes that centralised agencies may be able to cover the fixed costs of specialist functions which smaller decentralised agencies cannot, while Kovacic (2010) sees a successful regulatory agency as investing in knowledge and retaining high quality staff. Glachant et al (2013) notes that, in contrast to many economic models, in practice regulators have multiple objectives and so a key element of success is correctly aligning tools with tasks. In turn, the allocation of resources across different tasks, for example, the split of resources between monitoring and enforcement activities, influences the extent to which different objectives are met (Ferejohn and Shipan, 1990). However, despite the importance of resources to success, regulators may not be held accountable for the allocation of resources across tasks (Biber, 2008).

\footnotetext{
${ }^{20}$ While regulators deliberately not considering distributional impacts when taking decisions can be defended from an economic perspective, the fact that regulators' decisions will almost always have distributional consequences perhaps questions the feasibility of isolating regulators from political pressures.

${ }^{21}$ See the following subsection for a discussion of this issue.

22 Excluding RIAs.
} 
Turning to the behaviour of regulators, a distinction needs to be made between broad discussions of whether regulators act in the public interest or suffer from capture (Stigler, 1971; Peltzman, 1976; Becker, 1983) ${ }^{23}$, and the day-to-day activities of regulators. The former is a core part of the regulatory literature, while the latter is much less developed and may provide room for further research. Early work addressing day-to-day activities includes the study of US regulatory hearings (Joskow, 1972) ${ }^{24}$ and characterising regulators approach to regulatees as one of 'live and let live' unless prices are rising (Joskow, 1974). More recently, and for the UK, the regulator-regulatee relationship has been characterised as 'regulation by negotiation' with implicit and informal 'threats' being used to guide firm behaviour between formal regulatory reviews (Armstrong et al, 1994). Although, in the context of US environmental regulation, Pautz (2009) finds that between individual personnel on the ground the relationship between regulator and regulatee may involve a degree of trust rather than being totally adversarial. The presence of trust is perhaps a pre-requesite for complex implicit bargains to be achieved.

The notion of complexity also emerges in discussions of accountability with regulators having to respond to complex networks of public and private actors including elected officials, organised interests, the courts and the general public (Bignami, 2011a; Oliver et al, 2010). These networks also serve another purpose: providing regulators with the information they need to function. ${ }^{25}$ To obtain this information regulators must create venues where incentives exist, possibly via implicit 'rules of the game', for different stakeholders to truthfully reveal information (Brousseau and Glachant, 2011). Indeed, Coen (2005) suggests that a dynamic understanding develops between regulators and regulatees with regulators growing to prefer firms that engage constructively with consultation processes and excluding firms perceived as hindering consultations or providing misleading information. However, real participation by stakeholders in the regulatory process may be difficult due to differences of technique and language between different groups (Black, 2001).

The need for information ${ }^{26}$ can present dangers for regulators. In the running of network infrastructure there may be a highly technical 'infostructure' that monitors and manages access to networks which regulators may neither fully understand nor control (Pfleiger and Csikos, 2012). As significant, is the potential for regulatees to learn from their encounters with regulators and gain a strategic awareness of how to manage the information flows to regulators for their own advantage (Willman et al, 2003). The provision of information may also present an opportunity for regulatory capture with regulators selecting free, but 'biased', information over the costly production of 'unbiased' information by themselves (Agrell and Gautier, 2011; 2012). Indeed, ensuring that decision makers only receive 'desirable' information may be a key form of influence activity (Lee, 2013). Similarly, when regulatory decisions are reliant on firms' accounting data, manipulation of this data may occur (Pint, 1992; Garside et al, 2008; Cho and Sachs, 2012). Going one stage further, firms may alter their capital structure to gain a strategic advantage over regulators. In particular, firms may increase the amount of debt they hold to encourage regulators to set higher regulated prices (Spiegel and Spulber, 1994; Bortolotti et al, 2011; Cambini and Rondi, 2012).

\footnotetext{
${ }^{23}$ Dal Bo (2006) provides a relatively recent review of the regulatory capture debate.

${ }^{24}$ Lewis and Poitevin (1997) provide a more recent investigation of US regulatory hearings.

${ }^{25}$ There is empirical evidence that regulators are more active, the greater the information and knowledge they possess (Fremeth and Holburn, 2009; 2012).

${ }^{26}$ Berry (1984) identifies information as being the most important resource for regulators alongside the professional ability of their staff.
} 
When regulators can access high quality information there may still be questions about the quality of their analysis. Regulators may suffer from the same psychological imperfections as market participants (Tasic, 2011) or may give undue attention to the appearance of regulatory actions to external audiences rather than making decisions on the basis of robust and consistent models (Gifford, 2003). Alternatively, an agency's prior actions, by establishing precedents, may limit the agency's current policy options (Ferejohn and Shipan, 1990; Hyman and Kovacic, 2013).

\section{Regulators, Career Concerns and 'Revolving Doors'}

There are three areas of interest regarding individual regulators: (i) their characteristics, (ii) their method of appointment, and (iii) the ongoing incentives their career options provide. In all three cases a central issue is the capture of regulators by specific interests whether these be politicians or regulatees. As already noted, a key finding of this literature review is that while there is a substantive body of research which empirically investigates these issues for US PUCS, there is no equivalent research for utility regulators in the EU. The academic discussion of regulator characteristics in the UK is limited to high-level aggregate statistics (Thatcher, 2002a) and the impact of experience at the Competition Commission (Garside et al, 2013). The lack of a well-developed literature is a serious omission which needs to be addressed.

If one views the relationship between politicians and regulators as one of a principal and an agent, one issue concerns the desirable characteristics a principal should seek in an agent when making an appointment. For example, Spiller and Urbiztondo (1994) consider a principal's choice between a short-lived political appointee and a long-lived career civil servant, while others (Evans et al, 2011; Bubb and Warren, 2014) consider the desirability of deliberately appointing an agent with views at odds with those of the principal. Appointing an agent with conflicting views to the principal can overcome particular problems such as providing incentives for the production of information.

As noted in Section 2, requiring a regulator to run for election tends to result in market outcomes which are more favourable to consumers. When deciding between electing and appointing a regulator, there is a need to trade off the screening and disciplining potential of elections against the risk of elected decision makers pandering to public opinion and ignoring minority welfare (Maskin and Tirole, 2004). If regulators are appointed, the issue becomes one of whether the individuals who are appointed are the most qualified for the job. Kovacic (1997) expresses concern that political appointees with insufficient antitrust experience undermined the strength of the FTC, while Combes et al (2008) highlight the advantage that personal connections to job selection panels can give to economists within academia.

The fact that regulators are unlikely to be in a single job for life results in career concerns. The desire to maintain one's position or be promoted can create incentives for particular behaviours. When regulatory decisions are observable, regulators may place an undue emphasis on ensuring the consistency of their decisions (Menezes, 2009; Menezes and Roessler, 2010). Alternatively, career concerns may motivate a regulator to favour particular interests. Smyth and Soderberg (2010) note that Swedish regulators who favoured consumers in complaint cases had a lower probability of being replaced. In contrast, Leaver (2009) suggests that even regulators motivated by the public interest may wish to maintain a reputation for high ability. This reputational concern may result in low ability 
regulators being unduly lenient towards regulatees to ensure that the regulatees do not reveal the regulators' mistakes and, hence, their low ability.

In addition to works looking specifically at the career concerns of regulators, the economics and financial literatures consider how experts' concerns for preserving their reputation can affect the advice they provide. A common theme from the finance literature is for experts (investment analysts) to 'herd', i.e. for individuals to provide similar to the 'consensus' regardless of their private beliefs/information (Scharfstein and Stein, 1990; Devenow and Welch, 1996). A particular type of 'herding' results from concerns about future employability with Hong et al (2000) highlighting that providing forecasts away from the 'consensus' can increase the risk of inexperienced analysts being sacked. Similarly, when evaluating projects, Visser and Swank (2007) note that reputational concerns can encourage committees to present a 'united front', while Milbourn et al (2001) highlight that an expert may over-invest in information about a project's likely success as a means to limit the risk to their future reputation. Additionally, if the market for experts favours advice of a particular type or bias, experts may pander to this bias rather than reveal the true information they possess (Bourjade and Jullien, 2011).

However, regulators' reputational concerns are possibly a secondary issue in the regulatory literature compared to the debate surrounding the 'revolving door' of ex-regulators joining regulatees. In the US, revolving doors have attracted attention for a considerable period of time (Eckert, 1981; Cohen, 1986). However, not all authors view revolving doors as inherently negative. For example, Che (1995) notes that revolving doors may exist because both regulators and regulatees require staff with the same type of human capital. Supporting this argument, De Haan et al (2014) finds that SEC lawyers who were subsequently employed in the private sector were actually tougher enforcers of the law. ${ }^{27}$ Additionally, Salant (1995) suggests that 'revolving doors' help form implicit contracts between regulators and regulatees which support investments by the latter. If one believes 'revolving doors' are a serious means to facilitate regulatory capture, the obvious solution is to introduce legal provisions that ban them. Law and Long $(2011,2012)$ analyse the impact of such laws among PUCs. Law and Long find that while these laws do reduce regulators' subsequent employment in the private sector, they appear to have only a limited impact on market outcomes and are associated with regulatory agencies attracting less skilled individuals.

While the focus of debate surrounding 'revolving doors' is on the potential for regulatory capture, it is also worth noting the potential value in understanding how individual regulators frequently move between different regulatory agencies. Investigating these regulator career paths may provide an additional way to understand the links between different regulatory agencies, the definition of 'regulators' as a distinct profession and how ideas spread through the regulatory space. Former regulators may also join consultancies which advise a range of regulatory agencies and regulated firms. Consultancies may therefore provide another route for regulatory ideas to spread and an indirect mechanism for regulatees to influence former regulators' career options.

\section{Governance - Independence and Accountability}

\footnotetext{
${ }^{27}$ However, for Washington lobbyists, the continued political power of the legislator who formerly employed them is critical to the lobbyists' commercial value (Vidal et al, 2012). This points towards political connections, rather than human capital, being key in this particular arena.
} 
In this and the following section we consider the structure and governance of regulatory agencies as decision variables that can be consciously chosen. The economics literature focuses on the question of independence in terms of: (i) how politicians may gain control over agencies; and (ii) how to structure institutions to foster credible commitments through time that encourage long-term investments. It has much less to say about the topic of accountability except for the observation that accountability mechanisms can mean political actors retain a degree of influence over agency behaviour.

Recent (particularly European) political science research can be placed under the heading of 'regulatory governance'. Levi-Faur (2013) recognises in the 'marriage' between the regulation and governance literatures a turning point in the analysis of the regulatory form of state. Much earlier within the governance literature, and with a specific focus on the UK, Rhodes (1994) considers the "hollowing out" of the state driven by factors including privatisation, NPM, fragmentation of central government, creation of regulatory and quasi-administrative agencies and the impact of the EU. These themes continued with the concept of "new governance" (Rhodes, 1996), which could be expressed by the phrase "governing without government" and the private provision of public services (Rhodes, 1996). Similarly, Jordana and Levi-Faur (2004) consider the politics of regulation in the age of governance. However, the European political science literature is most notable for its focus on the independence and accountability of regulators. In particular, independence is viewed through the lense of independence from political actors as opposed to independence from regulatees or, in other words, avoiding regulatory capture.

\section{Delegation, Political Actors and Regulatory Agencies}

A central purpose of independent regulators was to delegate responsibility for technical decisions to regulators and remove politicians from the process. Despite this intention, a central question is the extent to which politicians retain some influence or control over regulatory agencies. In both the political science and economics literatures the relationship between politicians and regulators has been characterised as a principal-agent relationship with political principals having imperfect control over regulatory agents who may have different interests to their own. The political science literature also views the relationship between politicians and regulators as a fiduciary one based on the law and trust (Mitnick, 1973; 1975). The concept of a fiduciary relationship between politicians and regulators has been applied in the European context by Majone (1996).

Thatcher (2002a, 2002b) provides a number of cross-country studies regarding the delegation of regulatory powers to National Regulatory Authorities (NRAs). Thatcher provides guidance on the main characteristics an NRA should possess to be classified as (formally) independent highlighting the roles that major EU member states, and the EU itself, have played in the creation of independent NRAs. More generally, Thatcher and Stone Sweet (2002) introduced a special issue of West European Politics covering delegation to Non-Majoritarian Institutions (NMIs include NRAs, constitutional courts and central bankers etc) in Europe. ${ }^{28}$ Thatcher and Stone Sweet emphasise how delegation to NMIs has represented a major reform of governance within Europe. This theme is also highlighted in Levi-Faur (2013).

The need to include political actors in formal models of regulator behaviour has long been recognised, for example, see McChesney (1987) and Laffont and Tirole (1993). At the simplest level, politicians

${ }^{28}$ Pollack (2002) provides an equivalent analysis of NMIs for the US. 
may be able to extract rent from firms by threatening to impose costly regulation (McChesney, 1987). Also, even in an 'ideal' independent regulatory agency, politicians retain some control through the appointment process and oversight/review mechanisms (see Sections 3 and 4 for a more detailed discussion). In practice, regulators are rarely perfectly independent, instead having limited discretion and facing significant accountability mechanisms (Stern and Trillas, 2003). The implication is that political actors can never be fully removed from the regulatory process, even after the creation of independent regulatory agencies.

Recognising the continuing influence of politicians, a range of papers consider how firms may wish to capture them. However, assuming a principal-agent problem exists between politicians and regulators, this indirect capture will always be imperfect with regard to the regulatory process (Spiller, 1990). Indeed, Holburn and Van den Bergh $(2004,2008)$ consider how companies should allocate their influence activities to different institutions in order to achieve the capture of regulation. Other papers emphasis that the 'non-market' political strategy of firms can support their market strategy when aiming to gain a competitive advantage (Bonardi et al, 2005; 2006; Bonardi, 2008) or investigate when firms are most likely to be successful in achieving influence (Bonardi and Keim, 2005; Chong and Gradstein, 2010). It seems politicians are at particular risk of favouring a specific firm when the state has some ownership of the firm (Edwards and Waverman, 2006; Bortolotti et al, 2013).

Taking the reduction of political influence which regulator independence achieves to be desirable, there is then the question of how elected representatives should initially design regulatory institutions given the limited room for later influence. Subsequent to considering the design of institutions, there is the empirical question of how extensively politicians have been removed from the regulatory process. If political actors realise the significance of institutional structure to the implementation of regulation, the design of institutions will itself become a profoundly political act (Spiller and Ferejohn, 1992). For example, the decision costs of agencies can be altered to change agency behaviour (Spiller and Tiller, 1997). Since institutional design is a political act, it is argued that the establishment of institutions to constrain political opportunism is more likely when government is decentralised (Spiller, 1996).

A key decision is the extent of independence and the level of discretion given to an agency. One rationale for a greater delegation of powers compared to writing detailed procedural rules is that it allows regulatory agencies to respond more effectively to a complex and changing environment (Greenstein, 1993). Also, greater independence should increase the agency's commitment to the initiating government's policy choices (Steunenberg, 1996; Faure-Grimaud and Martimort, 2003). Yet greater independence increases the room for a regulator to collude with a regulatee. As a result, the government establishing an independent regulatory agency must determine the optimal trade-off between political independence and the risk of capture by firms (Faure-Grimaud and Martimort, 2003). If regulatory capture/corruption is a concern, increasing the number of actors involved in a decision can reduce the problem (Estache and Wren-Lewis, 2011). For example, splitting regulation across multiple specialised regulators increases the transaction costs for interest groups to arrange capture and so effective capture is less likely to be achieved (Laffont and Martimort, 1998, 1999). Also, over time regulator discretion may need to be curtailed to limit policy risk and the potential for capture (Parker, 1998; Martimort, 1999). 
A range of papers aim to assess the extent of regulator independence from politicians, an early example being Weingast and Moran (1983). Thatcher (2005) examines the regulatory states of Germany, the UK, France and Italy concluding that politicians do not seem to have used the powers they retained over regulatory authorities' personnel to direct or punish them. However, this could either indicate that politicians have taken delegation seriously and give regulatory agencies real discretion or that politicians have not needed to use their power due to the acquiescence of regulators. Other papers, including Crampes and Fabra (2005), Bel and Trillas (2005) and Oguz (2010), consider cases of continued political intervention in particular industries of particular countries. An alternative, more systematic, approach is to construct indices of independence to enable cross-country comparisons and econometric analysis of the impacts of independence. In the European context, the first author to do this was Gilardi $(2002 ; 2005 ; 2008)$ who developed a measure of regulatory independence based on Cuckierman et al's (1992) work looking at the independence of central banks. Gilardi's work, together with that of Hanretty and Koop (2012) and Larsen et al (2006), focuses on the formal independence ${ }^{29}$ of agencies. However, constructing such indices is not necessarily straightforward. For example, the formal independence of agencies may not be a good indicator of the practical, or de facto, independence of agencies (Maggetti, 2007; 2009; Trillas and Montoya, 2008; Montoya and Trillas, 2009). Also, there is ambiguity regarding whether independence should be measured as a single distinct characteristic or as part of a broader index covering the quality of regulatory governance (Gutierrez, 2003a; Waverman and Koutroumpis, 2011; Martin and Jayaker, 2013).

When measuring de facto independence, a range of different approaches have been taken to assess this potentially difficult to define quality. For example, Hanretty and Koop (2013) assess a variety of factors beyond formal independence including the rule of law, the coordination of the economy, the presence of veto players and the political salience of the regulated sector. In contrast, Ingold and Varone (2013) propose to examine the de facto independence of NRAs (including from regulatees and other co-regulators) by using social network analysis to identify the attributes and relational profiles of all the actors involved in the regulatory arrangements of the Swiss telecommunications sector. Maggetti et al (2013) extend social network analysis to investigate the correlation between NRAs' independence and their accountability, finding that Swiss sector regulators can be de facto independent and accountable at the same time. Lastly, Bertelli and Whitford (2009) tackle the issue of independence by linking it to elite perceptions of national regulatory quality. Bertelli and Whitford claim that market outcomes depend on perceptions of regulatory quality and that independent regulators facilitate elite perceptions of regulatory quality by providing a check to domestic political actors. While the political science literature has developed a variety of ways to measure independence, now that this has been completed it is unclear how the literature on independence can move further forward.

\section{Independence to Limit Policy Risk and Maximise Investment}

In the economics literature, the greatest perceived benefit of regulator independence is to provide a commitment to consistent policy which should help to encourage investment by firms. A fundamental problem is 'time inconsistency': a government/regulator may promise firms a high rate of return to encourage firms to invest, but then, once investments have taken place, the government/regulator has an incentive to renege on their promise and deliver lower prices to consumers. Realising that the

${ }^{29}$ Formal independence concerns the statutory duties of the regulator and the procedural requirements placed on an agency alongside its organisational structure and appointment procedures etc. 
commitment to a high rate of return is not credible firms will not invest. Importantly, delegation to an independent regulator is unlikely to solve this problem of time inconsistency by itself. However, by removing electoral cycles, independence may alleviate some of the pressures for political opportunism (Spiller, 1996) and, hence, the severity of the issue. A range of theoretical papers suggest mechanisms that can overcome the 'time inconsistency' problem in particular settings. If a regulator is sufficiently farsighted (long-lived), the desire of a regulator to maintain a reputation may allow a credible policy supporting investment to exist (Levine et al, 2005). Alternatively, if a regulator has the 'correct' level of pro-industry bias, the socially optimal level of investment can occur (Evans et al, 2008). Other theoretical solutions include it being costly for a regulator to obtain information about a regulatee (Sappington, 1986) or a regulator facing uncertainty about a firm's operating costs (Besanko and Spulber, 1992).

More generally, independent regulators, with a particular mandate or a sufficiently long appointment period, can address the policy risk associated with changing governments, governments changing policy or the responses to unexpected economic events (Holburn and Spiller, 2002a). ${ }^{30}$ However, ultimately, governments always have the ability to change policy, including the regulatory framework that has been established (Schmalensee and Stavins, 2013). Yet, by determining the status quo distribution of rents, the policies/institutions/contracts chosen by one government at a particular point in time can still influence the outcomes achievable by future governments (Aubert and Laffont, 2004). Since governments can renege on formal agreements, informal implicit contracts between governments and regulatees become important (Levy and Spiller, 1994). These implicit contracts rely on the 'institutional endowment' of countries and the creation of an independent regulatory agency as a specific institution can support these implicit contracts. For example, Gual and Trillas (2006) find that countries with weak investor protections are more likely to select an independent regulator. However, there is debate surrounding the compatibility of high regulator discretion in the UK and the notion of maintaining a credible implicit contract with regulatees (Spiller and Vogelsang, 1997; Harker, 2005).

Matching the theoretical literature on the value of commitment and reduced policy risk, is an empirical literature evaluating the impact of policy risk and regulator independence/governance on market outcomes. For example, in locations where energy policy has been less certain less investment in renewable energy has occurred (Fabrizio, 2013; Luthi and Wusterhagen, 2012). Although, Holburn and Zelner (2010) find support for a more complicated relationship involving firms' capabilities: electricity firms from countries with weaker institutions invest more in countries with greater policy risk to harness the skills they have learnt in their home country. Turning to the quality of regulator governance, a range of studies have found a positive association between regulator independence/high-quality governance and investment and/or network penetration (Gutierrez, 2003b; Zhang et al, 2005; Montoya and Trillas, 2009; Cambini and Rondi, 2011; Li and Lyons, 2012). Also, a number of studies associate regulator independence/high quality governance with improved operating efficiency by regulated firms (Gutierrez, 2003b; Zhang et al, 2005; Estache et al, 2006). However, some papers only find a relatively weak association between regulator quality/independence and market performance (Ugur, 2009; Trillas, 2010a).

\footnotetext{
${ }^{30}$ Policy risk can affect the ability of firms to invest by increasing their financial risk and borrowing costs. Hence, the cost of capital for firms - a key input for regulatory decision making - is endogenous to the regulatory process itself (Marshall et al, 1981; Norton, 1985).
} 


\section{Accountability and Legitimacy}

As one might expect, within the political science literature, accountability and legitimacy have been explored thoroughly for both the US and European Regulatory States due to their non-majoritarian nature (for example see: Graham, 1995; Braithwaite, 1999; Majone, 1999; Hanretty et al, 2012). Assessments have been made regarding whether organisational, appointment and/or transparency mechanisms can hold regulators to account and can legitimate their operation (Graham, 1995; Braithwaite, 1999; Majone, 1999). Particular points of emphasis in this literature include: the difficulty of balancing discretion and the control of regulators (Scott, 2000); how accountability is achieved through the interconnectedness of regulatory authorities with other public policy actors via transparent relationships (Prosser, 2010); and how transparency can "build publicness into public services" (Stirton and Lodge, 2001). Transparency and, in particular the transparency of agency decision-making, has become an important subtopic in the European regulatory literature on accountability. The literature on RIAs is a key element of this discussion and is described in Section 7. Also, providing accountability has been seen as a means to both limit the extent of regulation (House of Lords, 2004) and the potential for a regulator to be captured by particular interests (Koray and Saglam, 2005). As a result, there have been calls for greater transparency/accountability within the EU (Geradin, 2004a) and this has been mirrored by increased oversight of regulators over time (Wiener and Alemanno, 2010). The question is whether there are costs to increased accountability and oversight. Stern (1997) suggests that formal independence and accountability are not always necessary for effective regulation; instead, the critical factor is that all parties understand the 'rules of the game'.

\section{Governance - Pressures for Integration}

The previous section focussed on the aspects of governance that have already received considerable attention in the political science and economics literatures, namely independence and accountability. This section looks at other aspects of governance where additional research may be warranted. These areas all share a common theme of increasing integration within the regulatory space. The movement towards integration can be seen in the development of supranational regulation and its spread via regulator networks; the overlaps between competition policy and sector specific regulation; and the issue of combining separate sector regulators into multi-industry 'Super Regulators'.

\section{A need for Supranational Regulators?}

Many of the current challenges facing regulators have an international dimension, especially within the EU where there is an emphasis on fostering integration to meet single market objectives. The desirability of supranational regulation consists of two elements: (i) the challenges of effective regulation when firms have operations in foreign jurisdictions, and (ii) the benefits of integrated markets with harmonised regulations. However, the economics literature on federalism and the centralisation of organisations suggests that trade-offs exist when moving to centralised regulatory agencies.

The problem of having national regulations when firms trade internationally is that regulation in one country may result in externalities on other countries (Calzolari, 2001) or 'artificially' alter the pattern of international trade (Matteucci and Reverberi, 2005; Martimort and Verdier, 2012). Regulation in a 'home' market is likely to encourage overseas expansion into lightly regulated overseas markets (Urbiztondo et al, 2013; Billette de Villemeur and Pineau, 2012). However, despite decentralised regulation worsening the distortions associated with regulators' attempts to overcome limited 
information and offer incentives (Laffont and Pouyet, 2004; Calzolari and Scarpa, 2009), the potential for exports may increase the national welfare of the country containing the regulated sector (Matteuci and Reverberi, 2005; Calzolari and Scarpa, 2009).

The argument for supranational regulation is inevitably linked to the international integration of regulated industries (Finger and Varone, 2006; Estache and Wren-Lewis, 2012) and the belief that this development is desirable. The inherent nature of international integration for international rail and air travel (Yarrow, 1995) explains why international self-regulation initiatives in these industries predate the EC (Pfleiger and Csikos, 2012). In contrast, the difficulty of water transportation explains why there is generally little pressure for international regulation in this industry. The industries where cross-border regulation is most discussed in the European literature are energy and telecoms. It is no surprise that this emphasis corresponds to where the EC is trying hardest to establish single markets. ${ }^{31}$

The main benefit ascribed to integration is increased competition which will hopefully lead to efficiency gains and lower prices (Doane and Spulber, 1994; Kupper et al, 2009). Furthermore, a lack of integration may place corporate customers at an international competitive disadvantage due to higher input costs and a lack of scale (Cave and Corkery, 2009). For electricity markets, integration is also associated with a greater ability to handle the increased supply volatility expected from renewable energy sources (Green, 2008) and, also, should increase the security of supply (Helm, 2001; Glachant et al, 2008a). Both Cave and Corkery (2009) and Green (2008) explicitly compare the US and EU electricity grids to emphasise the relative absence of integration and co-ordination in the EU.

Yet, achieving integrated markets is not costless, particularly in the energy sector where physical transmission grids need to be constructed (Newbery, 2005). From an economic and technological perspective, designing a European energy grid in a unified fashion would be beneficial (Jamasb and Pollitt, 2005), however, such centralisation is politically problematic (Brunekeerft et al, 2005). These political pressures mean integration has to proceed in a voluntary way, however, the resulting 'ad hoc' order in which integration proceeds may limit the gains to future integration. This path dependency could restrict the final level of integration and in the short run integration does not guarantee that electricity prices will fall (Neuhoff and Newbery, 2005). Central to delivering the desirable market outcomes that the integration of physical infrastructure can bring is the co-ordination of regulation; without co-ordinated regulation the benefits of integrating physical infrastructure are limited (Neuhoff and Newbery, 2005; Agrell and Pouyet, 2008).

At a more abstract level, the desirability of international regulation can be linked to the economics literature on federalism (Trillas, 2008; 2010a; 2010b; 2011) with co-ordinated international regulation being akin to a centralised system and national regulation being akin to a decentralised system. A key conclusion is that neither complete centralisation nor complete decentralisation is likely to be the uniformly optimal framework in all situations; instead, the right responsibilities and tools need to be assigned to the right level of government (Oates, 1999). The benefits of a centralised structure are having sufficient resources to cover the fixed costs of specialist functions (Trillas, 2010a) and the internalisation of externalities (Neven and Roller, 2000; Ganuza and Huak, 2004; Trillas, 2010a; 2011; Tangeras, 2012; Montolio and Trillas, 2013). The costs of a centralised structure are a lower level of

\footnotetext{
${ }^{31}$ The differing suitability of supranational regulators and the appropriate institutional design of regulators in different sectors is discussed further in Coen and Doyle (2000).
} 
information about local conditions (Bardhan and Mookherjee, 2006) ${ }^{32}$ and a loss of accountability/legitimacy (Neven and Roller, 2000; Black, 2008). A decentralised structure of national regulators may also result in beneficial competition between regulatory agencies (Larouche, 2004). Where there is less consensus is whether centralisation reduces (Bardhan and Mookherjee, 2006; Trillas, 2010a) or increases (Neven and Roller, 2000; Ganuza and Huak, 2004) the risk of capture. The sophisticated answer is to say that whether capture is more or less likely in a centralised system depends on the relative sizes of different political forces at the national and supranational levels (Bardhan and Mookherje, 2000; 2002).

In the political science literature, governance is often associated with 'multi-level governance' and 'policy networks'. Unfortunately, there is a fundamental lack of clarity regarding the elements that constitute and define these terms, due to the relative difficulty of reducing them to measurable or easily observable characteristics. Nevertheless, very early on, the EU was depicted as a Regulatory State characterized by 'multi-level (or multi-tiered) governance' (for example, see Marks et al, 1996; Scott, 2002; Kohler-Koch and Rittberger (2006); Piattoni, 2009) given the nature of its local, national, and supra-national levels. Indeed, Eberlein and Grande (2000) highlight that the continued presence of national Regulatory States with distinctive idiosyncratic features confirms that the EU Regulatory State has not completely consumed the policy process at the member state level. Where the different levels of governance intersect, policy networks complement policy formation. The issue of policy networks has been explored by, among others, Borzel (1997) and Rhodes (2002).

A central question concerns the roles that justify the existence of policy networks. A key example of the link between policy networks and national regulatory authorities are European Regulatory Networks (ERNs) (Nicolaides, 2004). ${ }^{33}$ Nicolaides (2004) argues that these networks aim to solve the inherent difficulties of implementing policy at the national level which the European Commission faces. The heterogeneity of preferences and objectives among member states mean that for agreement to be reached at the EU level common rules are left purposefully broad; EU Directives set out the overall objectives of the policy, but policy implementation measures are decided at the national level to allow adaptation to the specific characteristics of individual member states. ERNs comprising national regulators respond to the need to reduce the inherent ambiguity of the rules agreed at the EU political level. ${ }^{34}$ Similarly, Eberlein and Grande (2005) see ERNs as a solution to the lack of institutional and political capacities to support supranational regulation at the EU level.

There are a range of other topics that can be linked to ERNs. For example, Coen and Thatcher (2008) highlight that ERNs represent an interesting form of 'double delegation' (downwards from the EC and upwards from national regulatory authorities). Looking downwards from ERNs, Maggetti (2014) focuses on the centrality of particular national regulators within the networks and the extent to which

\footnotetext{
32 Economics also considers centralisation versus decentralisation in organisations. A key trade-off is between the difficulty of communicating reliable information through the hierarchy of centralised organisations and the loss of control/co-ordination associated with decentralisation (Dessein, 2002; Mookherjee, 2006).

${ }^{33}$ ERNs are distinct from the creation of supranational European regulatory authorities due to membership of the former being voluntary.

${ }^{34}$ The fact that Directives are the primary instrument for all EU lawmaking means that the study of ERNs has taken place in variety of settings beyond network industries. For example, Maggetti and Gilardi (2011) consider the Committee of European Securities Regulators (CESR), Yesilkagit (2011) looks at the Data Protection Authority and Van Boetzelaer and Prince (2012) include an investigation of the European Network for the Implementation and Enforcement of Environmental Law (IMPEL).
} 
guidelines and codes of best practice agreed upon at the network level are implemented at the national level. Looking upwards from ERNs, Eberlein and Newman (2008) focus on ERNs that have been incorporated into EU-level regulatory processes and their transformation into European Regulatory Agencies (ERAs).

Despite their lack of EU-wide decision-making powers, ERAs ensure the coordination of national policies with EU Directives and represent the closer supervision of national practices. Several studies have focused on ERAs, the realm of their competence and the extent of their usefulness (Dehousse, 1997; Majone, 1997; Geradin; 2004a). ${ }^{35}$ In particular, Thatcher (2011) suggests that the earlier creation of regulatory authorities at the member state level and ERNs increases the difficulty of delegating substantial regulatory powers to ERAs as the earlier organisations do not want to be sidelined. It may be possible to draw parallels between this conflict at the supranational level and the conflict between US federal agencies and state-level PUCs as described by Childs (2001).

In terms of the potential for new research on regulatory networks, an interesting issue to explore is the use of networks by regulators as 'opportunity structures' to: (i) advance the preferred regulatory arrangements of the regulator's own country across the network, and (ii) to enhance the regulator's powers, reputation and/or resources in its home country. Maggetti (forthcoming) provides one study in this direction by noting that network membership was associated with a significant increase in a regulatory agency's responsibilities without a corresponding increase in resources.

Another potential implication of supranational regulation and the integration of markets is that there is a single 'optimal' form of regulatory institution. However, the institutional economics literature warns against 'one size fits all' policy recommendations with the success of particular regulatory institutions often being dependent on other idiosyncratic aspects of a country's institutional environment (Freeman, 2000; OECD, 2005; Spiller and Tommasi, 2005; Rodrik, 2008; Benitez et al, 2010; Haney and Pollitt, 2011). ${ }^{36}$ Often this literature is focused on less developed countries (Rodrik, 2008; Benitez et al, 2010), where there is likely to be a greater variety of institutional environments compared to a collection of developed countries like the EU. Hence, when considering policy harmonisation within the EU concerns about policy recommendations being poorly suited to particular institutional environments are likely to be less severe. However, differences in institutional environment do not disappear entirely within the EU. Most notably, the distinction between common law and civil law institutions (Larouche, 2006; La Porta et al, 2008) is present between the UK and other European countries. More specifically, Glachant (1998) questions whether the 'Electricity Pool' structure used in the UK in the 1990s could be used in other EU countries given its complex governance structure being reliant on the UK's institutional endowment.

At a more practical level, various papers document the extent of policy harmonisation across the EU, the development of EU-wide regulation and the challenges facing both of these processes. In many papers the differences in policies between member states are emphasised. For example, Dassler and Parker (2004) identify differences related to telecoms policy; Bellantuono and Boffa (2007) look at the differing positions of consumers and consumer associations in member states; Ugur (2009) identifies

\footnotetext{
${ }^{35}$ These studies mainly focus on ERAs in domains other than the network industries.

${ }^{36}$ The sensitivity of theoretical economics models' conclusions to information and market structures also suggests that the optimal regulatory framework is likely to vary by time and location (Baron, 1989; Armstrong and Sappington, 2007).
} 
large variations in regulatory quality; De Francesco et al (2012) highlights different levels of RIA implementation; while Bohringer et al (2008) and Meeus (2012) note countries' differing approaches to de-carbonise their economies. Cave and Shortall (2011) suggest that the diversity of policies, at least in relation to next generation telecoms networks, has resulted from the slow speed at which the EC formed its own policy and has created a problem of regulatory uncertainty. Another factor explaining the continuation of differences between member states is that to agree common policies individual countries must compromise on their desired outcomes. This requirement for compromise can limit the desirability of pursuing integration for individual countries (Ganuza and Huak, 2004; Hudson and Hudson, 2008). Similarly, political realities may mean the development of international regulators may be poorly planned leading to ad hoc and overly complex structures (Geradin, 2004a).

Despite these continuing differences, other papers highlight the influence EU policies and law have had on national policies and institutions (for example, see Borzel and Risse, 2000). In these latter papers there is a particular focus on the energy sector and the interplay with environmental rules at the EU level. For example, Newbery (1993) considers the impact of EU environmental rules on the market for British coal; Crampes et al (2009) considers how the EU's unbalanced energy mix means French nuclear plants receive a financial windfall due to their relative scarcity; and Sadowska and Willems (2013) highlight how EU competition law was used to further energy market integration in a Swedish competition case. Also, there are a range of papers which look explicitly at developments leading to a single EU energy market (Cameron, 2002; Jamasb and Pollitt, 2005; Newbery, 2005; Glachant and Leveque, 2009; 2011; European Commission, 2012) and how the EU's plans for reducing the energy sector's carbon emissions are closely linked to the EU's Emission Trading System (Newbery, 2008; Jones and Glachant, 2010; Delarue et al, 2011).

Developing the analysis of the ERNs as 'opportunity structures', how the regulatory practices of individual member states have influenced the form of harmonisation that has occurred at the EU level could be analysed. For example, has the UK harnessed moves towards single markets in regulated industries to export the model of privatised firms, liberalised markets and independent regulatory agencies to other EU countries? If so, what motivations lay behind this desire to export a particular regulatory model?

\section{The Boundary between Competition Policy and Regulation}

In the previous subsection, the boundaries between regulators were discussed from the perspective of different legal jurisdictions. However, the structure of regulators within any particular geographical entity can also be defined by the scope of their policy competence. This has led to the notion of a 'regulatory space' (Hancher and Moran, 1989) where there are a multiplicity of actors that influence (and are influenced by) a given regulatory authority. Aubin et al (2009) emphasise that within the EU tasks related to utilities regulation are distributed among a number of public actors. Mathieu et al (2011) operationalise this idea by proposing the notion of 'regulatory arrangements' and developing indices for specialisation, interaction and centralisation to understand how different bodies are involved in the 'regulatory arrangement'.

One aspect of the horizontal scope of sector regulators that has received particular attention is their relationship with general competition policy/law. The first question is why sector-specific regulation is needed over and above general competition law and enforcement? Permanent sector-specific regulatory measures may be necessary to counteract the market power of particular players (Geradin, 
2004b), but the presence of sector-specific regulation has also been seen as holding back competition within particular sectors (Oguz, 2010).

Arguably, the differences between regulation and competition law e.g. ex-ante vs ex-post remedies and persistent vs episodic enforcement (Tirole, 1999) suggest that they are complementary with each framework suiting different circumstances (De Streel, 2003; Geradin and Kerf, 2003; Geradin, 2004b). For example, there seems to have been a consensus that the UK water industry would always remain a series of regional monopolies and so regulation would have to be permanent (Littlechild, 1988b; Ogden and Anderson, 1995; Ogden, 1997). The explicit purpose of regulation is then to deliver outcomes for consumers that are equivalent to those achievable if competition was possible. Also, the need to control the continually high market power of incumbents in the electricity industry is often given as a justification for permanent ex-ante regulation in this sector (Newbery, 2004; Barquin et al, 2006; Willems and De Corte, 2008). However, Gilbert and Newbery (2008) highlight that in the US neither competition authorities' general merger rules nor those of sector-specific regulators effectively isolate the mergers in the electricity generation industry that reduce competition in a harmful fashion.

The implication of competition policy and regulation being complements, that sector regulators are a permanent feature of the market landscape, is not unchallenged. Various authors suggest that it is desirable for regulation to fade away as competition becomes strong enough to deliver favourable market outcomes (Baron, 1991; Weisman, 2006). Competition policy is favoured over regulation by these authors as a less invasive form of intervention. In this conception the continued existence of regulators is explained by their efforts to find a continuing purpose which may include stifling competition (Hausman and Sidak, 2014; Sappington and Weisman, 2012). Closely related to this notion that competition policy is preferable because it is less interventionist are papers that suggest regulators interfere too much in particular markets (Sidak and Spulber, 1998; Kahn, 2002; Hausman and Taylor, 2013) or require an unrealistic level of perfection from markets for interventions not to be justified (Littlechild, 2012). There are cases from the energy industry where in the absence of sector regulation, but the presence of competition policy framing negotiations and significant buyer power, successful market outcomes have been achieved (for example, see Glachant et al, 2008b). New Zealand represented a broader experiment in this regard, as it chose to rely solely on competition law to provide the regulatory framework for its utilities (Bergara and Spiller, 1997); however, the result was not wholly positive with courts becoming clogged with competition cases (Armstrong and Sappington, 2006).

In the European context, there is more discussion of the similarities between regulation and competition policy (Cave and Crowther, 2005) with the two fields being seen to overlap rather than having distinct zones of influence (De Hauteclocque, 2009; Hancher and Larouche, 2010; Cubbin and Stern, 2004; De Hauteclocque, 2013; Tapia and Mantzari, 2013). Key to this overlap is the fact that sector regulation within the EU must comply with EU competition law (Monti, 2008) and that, due to its limited powers, the EC may use competition law to achieve objectives more commonly associated with regulation (Temple-Lang, 2009; Tapia and Mantzari, 2013). Monti (2008), in particular, is concerned that requiring sector regulation to comply with EU competition law limits regulators' ability to pursue objectives other than competition and allocative efficiency. However, economists generally view the objectives that can be optimally delivered via market regulation in a narrow sense; the 
common consensus is that redistribution should be achieved through the tax and benefits system rather than by interfering with the competitive process of product markets.

\section{The Potential for Multi-Sector 'Super Regulators'}

While the boundary between competition policy and sector regulation has been extensively explored, there remains potential to investigate whether combining individual sector regulators into multisector 'Super Regulators' offers advantages. There are a range of papers relevant to this debate from a theoretical perspective. The variation between multi-sector and single sector regulators across the EU should mean that empirical evaluation of the impact of this structural choice on market outcomes is possible. ${ }^{37}$ Alternatively, regulators may combine different functional specialisms such as the combination of competition law and consumer law that formerly occurred within the UK's OFT (Cseres, 2013).

The notion of a 'Super Regulator' is most commonly associated with the creation of multi-sector regulators that combine regulators with similar expertise but where the policy externalities between regulatory authorities are limited e.g. combining a telecoms and rail regulator. This rationalisation of regulators may raise efficiency and reduce costs (Hampton, 2005) by removing fixed overheads. Beyond the removal of duplicated activities the logic of multi-sector regulators has to rely on there being a 'core competence' ${ }^{38}$ which the regulators can beneficially apply across all the markets they regulate. If such a competence or resource exists, then applying it to a range of markets can result in 'economies of scope' 39 (Panzar and Wilig, 1981). The most obvious source of a core competence among utility regulators are the skills and knowledge needed to regulate natural monopoly providers of network infrastructure. When considering the question of multi-sector regulators, the arguments discussed earlier regarding the potential benefits and weaknesses of centralised regulatory organisations, such as the possibility to establish specialist functions and the risks of capture (Laffont and Martimort, 1998, 1999), are also directly relevant.

Nevertheless, merging organisations presents potential risks, particularly if one thinks that differences between regulators are more significant than their similarities. Generally, organisations that focus on a small number of tasks are easier to manage than those performing multiple different tasks. Most fundamentally, it is more challenging to write contracts which motivate performance involving multiple objectives (Holmstrom and Milgrom, 1991; Rotemberg and Saloner, 1994; Dewatripont et al, 1999). ${ }^{40}$ Even without mergers, regulators, as public agencies, rarely face a single objective that is as simple to define as profit maximisation is for private firms (Tirole, 1994). Instead, public agencies are likely to face multiple objectives which may conflict leading to goal ambiguity and a reduction in performance (Finsinger and Vogelsang, 1981; Chun and Rainey, 2005; Carrigan, 2012). Facing conflicting objectives, an agency is likely to focus on only a few of them and neglect others (De Shazo

\footnotetext{
${ }^{37}$ The notion of regulating multiple utility sectors through a single regulatory body is not a new one, with this being the structure of PUCs in the US.

${ }^{38}$ Pralahad and Hamel (1990) define this term in relation to commercial enterprises emphasising that such a competence must result from organisational learning, be widely applicable and value enhancing, but difficult to replicate.

${ }^{39}$ Economies of scope are analogous to economies of scale, except that costs fall with the number of different product types being produced/markets served rather than with the quantity of a particular product being produced.

${ }^{40}$ Having multiple conflicting policy objectives may also affect the contracts written for regulatees (Crampes and Estache, 1998).
} 
and Freeman, 2005). In particular, Holmstrom and Milgrom (1991) analyse multi-task principal agent problems establishing the important insight that actors will focus their effort on those activities which provide the strongest incentives to perform. The implication of this is that tasks where performance is difficult to measure will be ignored, unless the allocation of tasks between actors is carefully designed.

Looking specifically at the merger of government agencies, Schinkel et al (2013) analyse the allocation of effort between basic minor tasks and complex major tasks. Schinkel et al find that agency mergers can result in reduced effort being applied to complex tasks, particularly if the merger is accompanied by a budget cut. A number of other papers emphasise the importance of achieving co-ordination between different activities/units within organisations. The limited resources available for coordination again suggest it is optimal for an organisation to focus on a limited range of core tasks (Dessein et al, 2013). The need for co-ordination may also guide how an organisation is split into subunits (Cremer, 1980), however, to achieve co-ordination requires the costly communication of information. Even if the need for co-ordination is strong, the challenges of credibly communicating truthful information ${ }^{41}$ may well favour a decentralised organisational structure (Alonso et al, 2008). The other issue that may arise in an organisation created from a merger is that individual employees may have to perform an increased number of tasks. Coviello (2014) finds empirically that highly qualified individuals (judges) have a lower productivity when they have to 'juggle' multiple tasks simultaneously, than when they can perform the same tasks sequentially. Lastly, since many economic models of regulation assume a single objective and a single policy tool (Glachant et al, 2013) the implications of multiple objectives and multiple policy tools on market outcomes are also less clearly understood.

The other way in which one could conceive 'Super Regulators' is involving the consolidation of regulators who share overlapping competences in particular areas. The subsection on supranational regulators highlighted the possibility of policy externalities between different national jurisdictions. However, policy externalities may also arise between different regulators facing differing objectives, information and instruments. For example, an environmental agency may tighten the environmental standards facing a water company without fully considering the cost implications for consumers (Cowan, 1993). ${ }^{42}$ Moreover, a single firm may face competing demands from multiple regulators. In economics, this situation can be modelled using a common agency framework (Bernheim and Whinston, 1986), where different regulators give competing incentive mechanisms (contracts) to a single firm (Martimort, 1996). The risk of a system involving multiple regulators is that the cummulative outcome of the narrow regulations and incentives may not be particularly desirable or even anticipated (Armstrong and Sappington, 2006). At the very least, the overlapping demands of differing regulators means that to fully understand regulation in a particular arena it may be necessary to look beyond the named sector regulator to the full constellation of regulators who influence the firms within a sector (Rommel and Verhoest, 2008). Combining separate regulators that share competences into single 'Super Regulators' may help to internalise some of the policy externalities mentioned above.

\section{Assessing Regulator Performance}

\footnotetext{
${ }^{41}$ See Section 4 for a more detailed discussion of the difficulties of achieving truthful and credible communication.

${ }^{42}$ Monast and Adair (2013) make similar points for electricity regulation in the US.
} 
The final, and most important, outstanding question to address regarding the Regulatory State in European network industries is to form an up to date and overarching conclusion about the performance of the Regulatory State over the past thirty years. There is no shortage of empirical evidence from econometric studies which could be harnessed in such an assessment. The task is to draw these narrowly focused studies, looking at particular performance criterions in particular sectors, into a cohesive whole. The range of studies is far too large to review in the present paper, instead, this section merely aims to characterise the methodological approaches that may be relevant when assessing the Regulatory State's performance.

In contrast to the abundance of studies looking at the performance of regulated markets in economics, the political science literature on the Regulatory State seems to lack an element dedicated to assessing regulator performance (excepting the papers on RIAs). This difference in the emphasis of the two disciplines is not surprising, given that political science is usually more concerned with 'how' and 'why' phenomena occurred, while economics tends to focus on the quantifiable 'effects' of phenomena. It is in determining the overall impact of the Regulatory State that the disciplines of politics and economics may meet most fruitfully.

Various books already provide a narrative discussion of the development of regulation within network industries and its impact from an economic perspective (Vickers and Yarrow, 1988; Armstrong et al, 1994; Helm and Jenkinson, 1998; Newbery, 1999; Van den Bergh and Pacces, 2012). These books also generally emphasise the UK experience. Other articles focus on the lessons from regulatory reform in the US over a 30-year time horizon (Hogan, 2002; Borenstein and Rose, 2007; Rose 2014). Further review articles look at specific issues such as electricity liberalisation (Joskow, 2008); the impact of deregulation on consumer markets (Cseres, 2008; NAO, 2008; Yarrow et al, 2008); the impact of incentive regulation (Kridel et al, 1996; Joskow, 2014); empirical studies of privatisation (Megginson and Netter, 2001); and the influence of regulation on investment (Guthrie, 2006). Given these existing reviews, any new review of the economic evidence regarding the Regulatory State's performance must systematically draw out cross-country and cross-sector comparisons ${ }^{43}$ within the European context. Moving beyond collating the existing evidence, the relevance of regulatory capture and the realisation that economists may suffer from capture (Zingales, 2013) means there could be value in investigating if publication bias exists concerning the economic analysis which is published in journals. Rigorous systematic reviews of empirical evidence are common in medicine and assessing the evidence on regulation could represent a valuable opportunity to extend this methodology to the social science arena.

\section{Defining a 'High Quality' Regulatory Agency and 'Good' Regulatory Performance}

Before one can assess the evidence on regulator performance one first needs to define what 'good' performance looks like. This a more complex task than it first appears: Should performance be assessed by the processes completed by regulators or the outcomes of the markets they regulate?

\footnotetext{
${ }^{43}$ There appear to be few papers with the explicit purpose of comparing regulation in different network industries (Stern (2004), Stern (2010) and Pollitt (2010) are exceptions). Also, Stern and Trillas (2003) compare the literature on independence for telecoms regulators against that for central banks.
} 
Should the performance of regulated industries be judged against 'independent' economic criteria ${ }^{44}$ or the stated objectives of regulators themselves? What if the objectives of regulators change through time? Are notions of 'best practice' applicable to regulation in all countries, sectors and time periods? How these questions are answered is likely to have a significant influence on the conclusions made about the performance of the Regulatory State.

Concerning regulator's objectives, there appears to be a high-level consensus that an economic regulator's key tasks are to protect consumers and, where possible, promote competition (Littlechild, 1994; Averitt and Lande, 1997; Ogden, 1997; Waddams-Price 2004). Although differences exist in the relative emphasis placed on these two objectives and how to balance them if they conflict. For example, possibly recognising that competition per se may not be sufficient to meet policymakers' objectives, the Financial Conduct Authority has promotion of 'effective' competition as an objective (Erta et al, 2013). Additionally, Field (2007) emphasises that long-term consumer interests should be the target of policymakers' objectives, hinting at potential trade-offs between policies that benefit consumers in the short-term and long-term. Adding further complexity, Livingstone et al (2007) note that Ofcom's objective is to promote the interests of citizen-consumers rather than merely consumers. Finally, while there may be agreement that regulators should aim to promote consumer interests, there may be a lack of agreement about the practical intermediate objectives that are most likely to deliver this overall goal. For example, Spanjer (2008) notes a change in emphasis over time regarding gas market debates from a focus on sweating assets to a focus on ensuring security of supply.

Where further research is probably warranted is in systematically tracking changes to regulators' objectives through time and variations in regulator objectives between jurisdictions. Such research might also aim to identify: (i) the extent to which regulator objectives are codified in legislation or in the documents produced by regulatory agencies; and (ii) whether there has been conflict between these codified objectives and the actual objectives pursued by regulators and/or the objectives attributed to regulators by external constituencies. While awareness of formal regulatory objectives among the general public is probably low, there is still value in investigating whether variations in regulators' emphasis on particular objectives through time mirrors changes in the general public's policy concerns.

Placing aside worries about the universality of 'best practice', a range of papers aim to describe best practice in different fields. In a general setting, Baldwin, Cave and Lodge (2012) aim to define 'good' regulation and what can be considered regulatory failure, while Hancher et al (2003) identify factors determining 'high quality' regulation and Kovacic (2010) reviews elements of good agency practice. Discussions of good practice in more specific areas include: desirable properties for incentive regulation mechanisms (Brown et al, 1991); benchmarking to support incentive regulation (Jamasb and Pollitt, 2000); principles of successful telecoms deregulation (Farrell, 1997); criteria to assess the institutional design of regulatory frameworks (Stern and Holder, 1999); best practice for the

\footnotetext{
${ }^{44}$ By 'independent' economic criteria we mean outcomes such as lower prices, increased investment or increased efficiency. Caution should be applied before evaluating regulatory agencies according to whether or not they conform to the structures or procedures recommended by particular theoretical economic models; the results of microeconomic models frequently depend on specific assumptions about the nature of competition, the information available to a regulator and the form of uncertainty. Unless a theoretical model's conclusions are supported by empirical evidence, it is generally best to view such models as highlighting potentially important trade-offs rather than providing solid policy recommendations.
} 
enforcement of consumer policy (Ogus et al, 2006); and principles to ensure security of supply in energy (Glachant et al, 2008b).

A second group of papers aim to review the performance of regulation in specific areas and then suggest improvements or changes to facilitate the achievement of certain objectives. For example, Glachant (2011) and European Commission (2012) outline the steps needed to establish a single European market in energy, while Lewin et al (2009) provides equivalent guidance for the deployment of next generation telecoms networks across the EU. Other papers provide recommendations for how consumer representation in the UK can be improved (DTI/HM Treasury, 2004; NAO, 2004), how consumer remedies can be made more effective (BRE/NCC, 2007; Garrod et al, 2008) and the steps required to achieve effective electricity regulation in the US (Joskow, 1997).

A general point about the wider economics literature is that investigations into 'regulation' often actually focus on indicators of the general regulatory burden within a society i.e. the costs imposed by regulation. In this sense, there can be the underlying sense that 'regulation' is bad. A distinction needs to be made between these papers and those focusing on the regulation of natural monopolies which most economists view as being legimately handled through explicit regulation. Nevertheless, there is still value in considering papers investigating how the efficiency of regulation can be improved. The general emphasis in these papers is on reducing the costs of compliance by streamlining regulators and regulatory processes to reduce complexity (Hampton, 2005; Littlechild, 2005; Department for BIS, 2013). Also, it is suggested that regulatory interventions and remedies should be based on firm empirical foundations and possibly subject to field experiments to provide concrete evidence of the interventions' benefits (Allcott and Mullainathan, 2010; OFT, 2009; Sunstein, 2011). However, the most widely discussed measure to improve regulatory efficiency and limit unnecessary regulation is the use of Regulatory Impact Assessments.

\section{Regulatory Impact Assessments (RIAs)}

RIAs aim to weigh up the costs and benefits of particular regulatory interventions to determine whether they should be implemented. RIAs are closely related to Cost-Benefit Analysis and both of these techniques have come to be used widely around the world (Sunstein, 2002; Wiener, 2013). As well as enabling 'better' decisions, RIAs are seen as a key part of the regulatory oversight process with RIAs forcing agencies to demonstrate their reasoning in a transparent manner. Radaelli has been the key author exploring the development of RIAs from a political science perspective. He explores how RIAs diffused and became an archetypal case of 'best practice' due to OECD influence and the EU's Better Regulation initiative (Radaelli, 2009a). However, Radaelli (2004) criticises the widespread adoption of RIAs without appropriate consideration to individual national contexts as it reduces them to check-box exercises rather than a real learning instrument. As with the concept of the Regulatory State itself, the concept of RIAs originated in the US and so comparative analysis of RIAs between the US and EU has been performed with differences in RIAs being linked to underlying differences in the conception of the Regulatory State (Radaelli and De Francesco, 2007).

RIAs can fulfil a variety of roles (Dunlop et al, 2012) including being an instrument of control, a tool for assessing regulatory authorities and a mechanism to ensure wider participation of stakeholders in decision-making. In the EU context, RIAs are also seen as instruments of learning between member states (Radaelli, 2009b). By representing an administrative rule that shapes the process and costs of decision making (Spiller and Tiller, 1997; Tiller and Spiller, 1999), RIAs can influence the outcome of 
the regulatory process. Hence, RIAs may constitute a form of political control rather than simply being a neutral decision making tool (Posner, 2001; Renda, 2006; Radaelli, 2010a; Duprat, 2012). Indeed, RIAs present a way to scrutinise regulators' decision-making, thus indirectly helping researchers to investigate their competence. For example, Desmarais and Hird (2013) examine the scientific citations in RIAs produced by US federal agencies to understand variations in the use of science in policymaking.

As the use of RIAs has grown, a literature has developed assessing their quality and drawing comparisons between different jurisdictions and regulators. These cross-country comparisons have been a key element of research by Radaelli $(2005,2009 b, 2010 b)$. Such studies assess the performance of regulators on the extent to which they follow particular procedures that are considered desirable. In these evaluations of RIAs as documents, there is a consistent finding that the extent and quality of economic evidence is poor (Renda, 2006; Torriti, 2008; 2010; 2011; Carroll, 2010; Marneffe and Vereeck, 2011). Although Fritsch et al (2013) finds some improvement in the quality of RIAs over time in the UK and EU. Particular criticism focuses on a lack of (or poor) quantification of the costs and benefits within RIAs (Renda, 2006; Marneffe and Vereeck, 2011). Carroll (2010) suggests that these failings result from a lack of commitment to RIAs, a lack of expertise and perhaps most fundamentally a lack of data. Indeed, Radaelli (2005; 2012), Radaelli et al (2008) and De Francesco et al (2012) all focus specifically on variations in the implementation of RIAs across the EU. ${ }^{45}$ Given the challenges of effectively implementing RIAs, Torriti (2011) even questions whether the assertion that RIAs are a rational decision making mechanism can be sustained. However, Harrington and Morgenstern (2004) highlight a key weakness with much of the RIA literature: the analysis focuses on the quality of the RIA documents rather than whether RIAs have had beneficial impacts on the objectives regulators are trying to achieve.

\section{Measurement Approaches and Challenges}

As already noted, assessing RIAs represents a particular method to evaluate regulator performance which emphasises process and outputs. Radaelli and Fritsch (2012) highlight that regulators can also be assessed using inputs, intermediate outcomes and final outcomes. One paper trying to link process and output measures of regulator quality to final market outcomes is Ugur (2009). Furthermore, a range of papers detail the different mechanisms and frameworks that can be used to assess regulator performance and the effectiveness of regulation (Magat et al, 1986; Joskow and Rose, 1989; Joskow, 2005; Brown et al, 2006; Parker and Kirkpatrick, 2012; Radaelli and Fritsch, 2012). As discussed in Section 5 , a range of papers construct indices to measure independence and the quality of governance. Also, there are papers suggesting particular performance measures/measurement methods to assess specific outcomes such as service quality (Chau, 2002; Sappington, 2005; Growitsch et al, 2009), the extent of market liberalisation (Green et al, 2009) and regulatory risk (Strausz, 2011).

Other papers identify particular issues and challenges with assessing regulatory outcomes. Spiller (1983) suggests that conclusions may be misleading if the researcher assumes all firms in an industry have homogeneous interests. Winston (1998) notes that the full impact of deregulation may take considerable time to emerge but that political pressures may result in deregulation being curtailed before these benefits become apparent. Similarly, Zelner et al (2009) warns that governments may return to implementing old policy objectives even when there is no formal repeal of a new policy. In contrast, Earl et al (2011) suggest that a difficulty of empirical analysis in telecoms markets is that the

\footnotetext{
45 Hahn and Litan (2005) and Wiener and Alemanno (2010) make comparisons between the US and EU regarding the implementation of broader measures to foster regulatory oversight.
} 
markets may change while data is being collected due to rapid technological developments. However, possibly the biggest challenge for evaluating the Regulatory State's performance is identified by Yarrow (1989). Yarrow suggests that market outcomes depend on the incentive structures which result from the total policy bundle of privatisation, competition and independent regulatory agencies. Since these three policy elements often change at the same time it can be difficult to identify the impact of a single policy element, such as independent regulatory agencies, in isolation.

As an alternative to quantitative studies, a number of papers draw lessons about effective regulation by considering particular cases of regulatory failure. For example, Joskow (2001) looks at the factors that led to the California energy crisis in 2000, while Nillesen and Pollitt (2004) consider the costs of the Dutch electricity regulator changing its method for calculating RPI-X four times in two and a half years. A final approach that might be illuminating is to compare the market outcomes resulting from policy measures with the initial predictions made by both regulators and academics. For example, Parker (2013) uses official government records to show that some of the problems of UK rail privatisation had been anticipated by the government and Joskow (2003) compares US energy policy forecasts from 1979 with actual experience. A broader collation of predictions and projections across the network industries could be valuable. A range of academic papers include discussions of future outcomes, particularly for the electricity industry. Green (1991) suggests that the provisions of the UK's electricity privitisations might result in a lack of competition and weak incentives to invest, while Green and Newbery (1997) and Green and McDaniel (1998) contemplate the results of introducing retail competition into the UK energy market. Also, Yarrow (1991) and Joskow (1996b) make predictions about the objectives that will be emphasised in future energy regulation.

\section{Conclusions}

The most obvious conclusion to draw from this literature review is the vast scale of the literature that has relevance to investigating the Regulatory State along with the literature's diversity. Without aiming to be exhaustive, this literature review cites over six hundred and fifty separate works. It is crucial to realise that while the term Regulatory State is almost totally absent from the economics literature there is still a vast number of economics papers that are directly relevant to understanding the Regulatory State and its performance. The richness of this literature is indicated by the presence of an economics journal dedicated to regulation, the Journal of Regulatory Economics, and other policy focussed journals such as Utilities Policy, Energy Economics and Energy Policy.

However, despite the richness of this literature, the absence of the term Regulatory State from economics suggests that more can be done to draw the economics, law and political science literatures together to form an overarching assessment of this key form of governance. To construct solid conclusions about the effectiveness of the Regulatory State a major effort will be required to collate all the empirical studies in the economics literature relating to the performance of regulated network industries over the past 30 years. The Regulatory State has now existed in the UK's network industries for a sufficient period of time that the present seems an opportune moment to conclusively map its long-term development and consequences. The conclusions drawn from the UK experience should provide important guidance regarding the outcomes of more recent moves to delegate the regulation of network industries to independent regulatory agencies in other jurisdictions. 
Moreover, and as discussed at length, the preoccupation within political science has been on assessing only two aspects of regulatory authorities, in particular, their independence from politics and accountability. This focus has occurred to such an extent that independence has almost come to be seen as the key measure of a 'good regulator', as the precise definition of a 'good regulator' has proven difficult to establish. The difficulty of defining the elements constituting a 'good regulator' partly results from the embedded nature of regulators within the wider institutional landscape. Given this embeddedness, one final area where new research may be warranted is on the impact the emergence of the Regulatory State has had on other institutions and public bodies. While such analysis has been undertaken in relation to possible Europeanisation, studies looking at the impact of regulatory agencies at the national level appear to be missing.

It is also significant that in the literature on the Regulatory State there are specific areas of emphasis, such as the position of consumers, courts and expertise, where room remains for further valuable research. To investigate these topics innovative approaches may be required due to the relative lack of data. Indeed, a key finding of this literature review is that compared to US PUCS the information available on the characteristics of utility regulators in the European setting is poor and largely uncollated. This finding indicates limits on the accountability of the European Regulatory State which may threaten its legitimacy. Further academic study of the European Regulatory State can add considerable value by starting to address this shortfall in information.

\section{References}

- Acemoglu, D., M. A. Dahleh, I. Lobel and A. Ozdaglar (2011), 'Bayesian learning in social networks', Review of Economic Studies, 78(4), pp. 1201-1236

- Aghion, P., Y. Algan, P. Cahuc and A. Shleifer (2010), 'Regulation and Distrust', Quarterly Journal of Economics, 125(3), pp. 1015-1049

- Agrell, P.J. and A. Gautier (2011), 'A theory of soft capture', CREPP Working Paper No. 2011/07, Available at: http://ideas.repec.org/p/rpp/wpaper/1107.html

- Agrell, P.J. and A. Gautier (2012), 'Rethinking regulatory capture', Chapter 14 in J.E. Harrington Jr and Y. Katsoulacos (eds.) 'Recent Advances in the Analysis of Competition Policy and Regulation', Cheltenham: Edward Elgar, pp. 286-302

- Agrell, P. J. and J. Pouyet (2008), 'Regulatory competition in network interconnection pricing', Review of Network Economics, 7(1)

- Allcott, H. and S. Mullainathan (2010), 'Behavioral science and energy policy', Science, 327(5970), pp. 1204-1205

- Alonso, R., W. Dessein and N. Matouschek (2008), 'When Does Coordination Require Centralization?', American Economic Review, 98(1), pp. 145-179

- Anderson, J. E. (1962), 'The Emergence of the Modern Regulatory State', Public Affairs Press

- Armstrong, M. (2008), 'Interactions between competition and consumer policy', Competition Policy International, 4(1), pp. 97-147

- Armstrong, M., S. Cowan, and J. Vickers (1994), 'Regulatory reform: economic analysis and British experience', Cambridge, Massachusetts: MIT Press

- Armstrong, M. and D.E. Sappington (2006), 'Regulation, competition, and liberalization', Journal of Economic Literature, 44(2), pp. 325-366

- Armstrong, M. and D.E. Sappington (2007), 'Recent developments in the theory of regulation', Chapter 27 in M. Armstrong and R. Porter (eds.) 'Handbook of industrial organization, Volume 3', Amsterdam: Elsevier, pp. 1557-1700 
- Aubert, C. and J.-J. Laffont (2004), 'Political renegotiation of regulatory contracts', Working Paper, Available at: http://128.118.178.162/eps/game/papers/0506/0506002.pdf

- Aubin, D., K. Verhoest, E. Mathieu and J. Matthys (2009), 'Limited Fragmenation through Coordination in the Regulation of the Energy and Telecommunications Sectors in Belgium', KU Leuven, Working Paper, Available at: https://lirias.kuleuven.be/handle/123456789/296711

- Australian Communications and Media Authority (ACMA) (2011a), 'Community research on informed consent', Qualitative research report, March 2011, Available at: http://www.acma.gov.au/Industry/Telco/Reconnecting-the-customer/Publicinquiry/informed-consent-community-research-reconnecting-the-customer-acma

- Australian Communications and Media Authority (ACMA) (2011b). '3G mobile bill-payers' understanding of billing and charging arrangements', Quantitative research report, June 2011, Available at: http://www.acma.gov.au/theACMA/Library/researchacma/Snapshots-andpresentations/3g-users-billing-understanding-research-reconnecting-the-customer-acma

- Averitt, N.W. and R.H. Lande (1997), 'Consumer sovereignty: A unified theory of antitrust and consumer protection law', Antitrust Law Journal, 65(3), pp. 713-756

- Baldwin, R., M. Cave, and M. Lodge (2012), 'Understanding regulation: theory, strategy, and practice', Oxford: Oxford University Press

- Banerjee, A. and D. Fudenberg (2004), 'Word-of-mouth learning', Games and Economic Behavior, 46(1), pp. 1-22

- Bardhan, P. and D. Mookherjee (2000), 'Capture and governance at local and national levels', American Economic Review, 90(2), pp. 135-139

- Bardhan, P. and D. Mookherjee (2002), 'Relative capture of local and central governments: An essay in the political economy of decentralization', Working Paper, Center for International and Development Economics Research, Available at: http://escholarship.org/uc/item/9gx7t5hd

- Bardhan, P. and D. Mookherjee (2006), 'Decentralisation and Accountability in Infrastructure Delivery in Developing Countries', Economic Journal, 116(508), pp. 101-127

- Baron, D.P. (1988), 'Regulation and legislative choice', RAND Journal of Economics, pp. 467477

- Baron, D.P. (1989), 'Design of regulatory mechanisms and institutions', Chapter 24 in R. Schmalensee and R. Willig, 'Handbook of Industrial Organization, Volume 2', Amsterdam: Elsevier, pp. 1347-1447

- Baron, D. P. (1991), 'Information, incentives, and commitment in regulatory mechanisms: regulatory innovation in telecommunications', Chapter 4 in M.A. Einhorn (ed.) 'Price caps and incentive regulation in telecommunications', Topics in Regulatory Economics and Policy Series 6, Springer US, pp. 47-75

- Barquin, J., L. Bergman, C. Crampes, J-M. Glachant, R. Green, C. Von Hirschhausen, F. Leveque and S. Stoft (2006), 'The Acquisition of Endesa by Gas Natural: Why the Antitrust Authorities Are Right to Be Cautious', The Electricity Journal, 19(2), pp. 62-68

- Bartl, M. (2010), 'The Affordability of Energy: How Much Protection for the Vulnerable Consumers?', Journal of Consumer Policy, 33(3), pp. 225-245

- Bauer, J. (1927), 'The Problem of Effective Public Utility Regulation', American Economic Review, 17(1), pp. 123-127

- Bawn, K. (1995), 'Political Control Versus Expertise: Congressional Choices about Administrative Procedures', American Political Science Review, 89(1), pp. 62-73 
- Baye, M. R. and J. D. Wright (2011), 'Is Antitrust Too Complicated for Generalist Judges? The Impact of Economic Complexity and Judicial Training on Appeals', Journal of Law and Economics, 54(1), pp. 1-24

- Becker, G.S. (1983), 'A Theory of Competition Among Pressure Groups for Political Influence', Quarterly Journal of Economics, 98(3), pp. 371-400

- Beesley, M. E. and S. C. Littlechild (1989), 'The regulation of privatized monopolies in the United Kingdom', RAND Journal of Economics, 20(3), pp. 454-472

- Bel, G. and F. Trillas (2005), 'Privatization, corporate control and regulatory reform: the case of Telefonica', Telecommunications Policy, 29(1), pp. 25-51

- Bellantuono, G. (2010), '2.0 Comparing regulatory decision-making in the energy sector', Comparative Law Review, 1(2)

- Bellantuono, G. and F. Boffa (2007), 'Energy regulation and Consumers' interests: Final Report', Regional Technical Center of Research on European Consumption (CTRRCE), July 2007, Available at: http://eprints.biblio.unitn.it/1396/Benitez, D., A. Estache and T. Soreide (2010), 'Dealing with politics for money and power in infrastructure', World Bank Policy Research Working Paper No. 5455, Available at: http://papers.ssrn.com/sol3/papers.cfm?abstract_id=1697962

- Bennett, M., J. Fingleton, A. Fletcher, L. Hurley and D. Ruck (2010), 'What does Behavioural Economics Mean for Competition Policy', Competition Policy International, 6(1), pp. 111-137

- Bergara, M. E. and P. T. Spiller (1997), 'The introduction of direct access in New Zealand's electricity market', Utilities Policy, 6(2), pp. 97-105

- Bernheim, B. D. and M. D. Whinston (1986), 'Menu auctions, resource allocation, and economic influence', Quarterly Journal of Economics, 101(1), pp. 1-31

- Bernstein, J. I. and D. E. Sappington (1999), 'Setting the X factor in Price-Cap Regulation Plans', Journal of Regulatory Economics, 16(1), pp. 5-26

- Berry, W. D. (1979), 'Utility Regulation in the States: the policy effects of professionalism and salience to the consumer', American Journal of Political Science, 23(2), pp. 263-277

- Berry, W. D. (1984), 'An Alternative to the Capture Theory of Regulation: The Case of State Public Utility Commissions', American Journal of Political Science, 28(3), pp. 524-558.

- Bertelli, A. M. and A. B. Whitford (2009), 'Perceiving Credible Commitments: How Independent Regulators Shape Elite Perceptions of Regulatory Quality', British Journal of Political Science, 39(3), pp. 517-537

- Besanko, D. and D. F. Spulber (1992), 'Sequential-equilibrium investment by regulated firms', RAND Journal of Economics, 23(2), pp. 153-170

- Besley, T. and S. Coate (2003), 'Elected versus appointed regulators: Theory and evidence', Journal of the European Economic Association, 1(5), pp. 1176-1206

- Better Regulation Executive and National Consumers Council (2007), 'Warning: Too Much Information Can Harm', November 2007, Available at: www.berr.gov.uk/files/file44588.pdf

- Biber, E. (2008), 'Two Sides of the Same Coin: Judicial Review of Administrative Agency Action and Inaction', Virginia Environmental Law Journal, 26, pp. 461-502

- Bignami, F. (2011a), 'From Expert Administration to Accountability Network: A New Paradigm for Comparative Administrative Law', American Journal of Comparative Law, 59(4), pp. 859908

- Bignami, F. (2011b), 'Cooperative Legalism and the Non-Americanization of European Regulatory Styles: The Case of Data Privacy', American Journal of Comparative Law, 59(2), pp. 411-461 
- Billette de Villemeur, E. and P-O. Pineau (2012), 'Regulation and electricity market integration: When trade introduces inefficiencies', Energy Economics, 34(2) pp. 529-535Black, J. (2001), 'Proceduralizing regulation: Part II', Oxford Journal of Legal Studies, 21(1), pp. 33-58

- Black, J. (2008), 'Constructing and contesting legitimacy and accountability in polycentric regulatory regimes', Regulation \& Governance, 2(2), pp. 137-164.

- Black, J., P. Muchlinski, and P. Walker (eds.) (1998), 'Commercial Regulation and Judicial Review', Oxford: Hart Publishing

- Blank, L. and J. W. Mayo (2009), 'Endogenous regulatory constraints and the emergence of hybrid regulation', Review of Industrial Organization, 35(3), pp. 233-255

- Böhringer, C., H. Koschel and U. Moslener (2008), 'Efficiency losses from overlapping regulation of EU carbon emissions', Journal of Regulatory Economics, 33(3), pp. 299-317

- Bonardi, J-P. (2008), 'The internal limits to firms' nonmarket activities', European Management Review, 5(3), pp. 165-174

- Bonardi, J-P., A. J. Hillman and G.D. Keim (2005), 'The attractiveness of political markets: Implications for firm strategy', Academy of Management Review, 30(2), pp. 397-413

- Bonardi, J-P. and G. D. Keim (2005), 'Corporate political strategies for widely salient issues', Academy of Management Review, 30(3), pp. 555-576

- Bonardi, J-P., G.L.F. Holburn, and R.G. Vanden Bergh (2006), 'Nonmarket strategy performance: Evidence from US electric utilities', Academy of Management Journal, 49(6), pp. 1209-1228

- Borenstein, S. (2012), 'The Redistributional Impact of Nonlinear Electricity Pricing', American Economic Journal: Economic Policy, 4(3), pp. 56-90

- Borenstein, S. and N. L. Rose (2007), 'How airline markets work... or do they? Regulatory reform in the airline industry', National Bureau of Economic Research, Working Paper No. 13452, Available at: http://www.nber.org/papers/w13452.pdf

- Borenstein, S. and L. W. Davis (2012), 'The Equity and Efficiency of Two-Part Tariffs in US Natural Gas Markets, Journal of Law and Economics, 55(1), pp. 75-128

- Bortolotti, B., C. Cambini, L. Rondi and Y. Spiegel (2011), 'Capital Structure and Regulation: Do Ownership and Regulatory Independence Matter?', Journal of Economics \& Management Strategy, 20(2), pp. 517-564.

- Bortolotti, B., C. Cambini, and L. Rondi (2013), 'Reluctant regulation', Journal of Comparative Economics, 41(3), pp. 804-828

- Börzel, T.A. (1997), 'What's so special about policy networks? An exploration of the concept and its usefulness in studying European governance', European Integration online Papers (EloP), 1(16)

- Börzel, T.A. and T. Risse (2000), 'When Europe hits home: Europeanization and domestic change', European Integration online Papers (EloP), 4(15)

- Bourjade, S. and B. Jullien (2011), 'The roles of reputation and transparency on the behavior of biased experts', RAND Journal of Economics, 42(3), pp. 575-594

- Braithwaite, J. (1999), 'Accountability and Governance under the New Regulatory State', Australian Journal of Public Administration, 58(1),pp. 90-94

- Braithwaite, J. (2005), 'Neoliberalism or Regulatory Capitalism', Regulatory Institutions Network, Occasional Paper 5, October 2005, Available at: http://papers.ssrn.com/sol3/papers.cfm?abstract_id=875789 
- Braithwaite, J. (2006), 'The Regulatory State?' Chapter 21 in R.A.W. Rhodes, S.A. Binder and B.A. Rockman (eds.) Oxford Handbook of Political Institutions, Oxford: Oxford University Press, pp. $407-430$

- Braithwaite, J. (2011), 'The Essence of Responsive Regulation', University of British Columbia Law Review, 44, pp. 475-520

- Braithwaite, J. and I. Ayres (1992), 'Responsive Regulation: Transcending the Deregulation Debate', Oxford Socio-Legal Studies, New York: Oxford University Press

- Brake, B. and P. J. Katzenstein (2013), 'Lost in Translation? Nonstate Actors and the Transnational Movement of Procedural Law', International Organization, 67(4), pp. 725-757

- Brennan, T. J. (2007), 'Consumer preference not to choose: Methodological and policy implications', Energy Policy, 35(3), pp. 1616-1627

- Bressman, L. S. (2000), 'Schechter Poultry at the Millennium: A Delegation Doctrine for the Administrative State', Yale Law Journal 109(6), pp. 1399-1442

- Brousseau, E. and J.-M. Glachant (2011), 'Regulators as Reflexive Governance Platforms', Competition and Regulation in Network Industries, 12(3), 194-210

- Brown, R. A. (1924), 'The Functions of Courts and Commissions in Public Utility Rate Regulation', Harvard Law Review, 38(2), pp. 141-179

- Brown, L., M. Einhorn and I. Vogelsang (1991), 'Toward Improved and Practical Incentive Regulation', Journal of Regulatory Economics, 3(4), pp. 323-338

- Brown, A. C., J. Stern and B. Tenenbaum (2006), 'Handbook for Evaluating Infrastructure Regulatory Systems', Washington D.C.: The World Bank

- Brunekreeft, G., K. Neuhoff and D. Newbery (2005), 'Electricity transmission: An overview of the current debate', Utilities Policy, 13(2), pp. 73-93

- Bubb, R. and P. Warren (2014), 'Optimal Agency Bias and Regulatory Review', Journal of Legal Studies, 43(1), pp. 95-135

- Bushnell, J. B. and E. T. Mansur (2005), 'Consumption under Noisy Price Signals: A Study of Electricity Retail Rate Deregulation in San Diego', Journal of Industrial Economics, 53(4), pp. 493-513.

- Cafaggi, F. and H-W. Micklitz (eds.) (2009), 'New Frontiers of Consumer Protection: The Interplay between Private and Public Enforcement', Intersentia

- Calzolari, G. (2001), 'The theory and practice of regulation with multinational enterprises', Journal of Regulatory Economics, 20(2), pp. 191-211

- Calzolari, G. and C. Scarpa (2009), 'Footloose monopolies: regulating a "national champion"', Journal of Economics \& Management Strategy, 18(4), pp. 1179-1214

- Cambini, C. and L. Rondi (2011), 'Regulatory Independence, Investment and Political Interference: Evidence from the European Union', EUI Working Papers RSCAS 2011/42, Available at: http://cadmus.eui.eu/bitstream/handle/1814/18058/Rscas_2011_42.pdf?sequence=1

- Cambini, C. and L. Rondi (2012), 'Capital structure and investment in regulated network utilities: evidence from EU telecoms', Industrial and Corporate Change, 21(1), pp. 31-71

- Cameron, P. D. (2002), 'Competition in Energy Markets: Law and Regulation in the European Union', Oxford University Press

- Caporaso, J. A. (1996), 'The European Union and forms of State: Westphalian, Regulatory or Post-Modern?', Journal of Common Market Studies, 34(1), pp. 29-52 
- Carrigan, C. (2012), 'Structured to Fail? Explaining Regulatory Performance under Competing Mandates', PhD Thesis, Harvard University, Available at: http://dash.harvard.edu/handle/1/9367009

- Carroll, P. (2010), 'Does regulatory impact assessment lead to better policy?', Policy and Society, 29(2), pp. 113-122

- Cave, M. and P. Crowther (2005),' Pre-emptive competition policy meets regulatory anti-trust', European Competition Law Review, 26(9), pp. 481-490

- Cave, M. and M. Corkery (2009), 'Regulation and Barriers to Trade in Telecommunications Services in the European Union', CEsifo Working Paper Series No. 2678, Available at: http://www.cesifo-group.de/portal/page/portal/DocB ... 6/cesifo1_wp2678.pdf

- Cave, M. and T. Shortall (2011), 'The extended gestation and birth of the European Commission's Recommendation on the regulation of fibre networks', info, 13(5), pp. 3-18

- Cengiz, F. (2011), 'Judicial Review and the Rule of Law in the EU Competition Law Regime after Alrosa', European Competition Journal, 7(1), pp. 127-153

- Chau, V. S. (2002). "Report on customer service performance measures in UK network industries: squeezing hard to improve quality." Centre for Competition and Regulation Working Paper, CCR: 02-03.

- Che, Y-K. (1995), 'Revolving doors and the optimal tolerance for agency collusion', RAND Journal of Economics, 26(3), pp. 378-397

- Che, Y-K. and N. Kartik (2009), 'Opinions as Incentives', Journal of Political Economy, 117(5), pp. $815-860$

- Childs, W. R. (2001), 'State Regulators and Pragmatic Federalism in the United States, 18891945', Business History Review, 75(04), pp. 701-738

- Cho, S. Y. and K. D. Sachs (2012), 'Earnings management and deregulation: The case of motor carriers', Journal of Accounting and Public Policy, 31(5), pp. 451-470

- Chong, A. and M. Gradstein (2010), 'Firm-Level Determinants of Politcal Influence', Economics \& Politics, 22(3), pp. 233-256

- Christensen, T. (2012), 'Post-NPM and changing public governance', Meiji Journal of Political Science and Economics, 1, pp. 1-11

- Chun, Y. H. and H. G. Rainey (2005), 'Goal Ambiguity in US Federal Agencies', Journal of Public Administration Research and Theory, 15(1), pp. 1-30

- Ciriolo, E. (2011), 'Behavioural economics in the European Commission: past, present and future', Oxera, Agenda, January 2011, Available at: http://www.scpknowledge.eu/knowledge/behavioural-economics-european-commission-past-present-andfuture

- Civil Aviation Authority (2005), 'Airport Regulation - The Process for Constructive Engagement', London: Civil Aviation Authority

- Clifton, J., D. Diaz-Fuentes, et al. (2011), 'Citizens, Public Services and European Regulation: The Spanish Case (in Spanish)', CIRIEC España Revista de Economía Pública Social y Cooperativa, Working Paper, Available http://papers.ssrn.com/sol3/papers.cfm?abstract_id $=1762644$

- Coen, D. (2005), 'Business-Regulatory Relations: Learning to Play Regulatory Games in European Utility Markets', Governance, 18(3), pp. 375-398

- Coen, D. and C. Doyle (2000), 'Liberalisation of Utilities and Evolving European Regulation', Economic Outlook, 24(3), pp. 18-26 
- Coen, D. and M. Thatcher (2008), 'Network Governance and Multi-level Delegation: European Networks of Regulatory Agencies', Journal of Public Policy, 28(01), pp. 49-71

- Cohen, J. E. (1986), 'The dynamics of the" revolving door" on the FCC', American Journal of Political Science, 30(4), pp. 689-708

- Colton, R.D. (2006), 'Municipal Aggregation for Retail Natural Gas and Electric Service: Potentials, Pitfalls and Policy Implications', Fisher, Sheehan \& Colton, Public Finance and General Economics, Belmont, Massachusetts

- Combes, P.-P., L. Linnemer and Visser, M. (2008), 'Publish or peer-rich? The role of skills and networks in hiring economics professors', Labour economics, 15(3), pp. 423-441

- Coviello, D., A. Ichino and N. Persico (2014), 'Time Allocation and Task Juggling', American Economic Review, 104(2), pp. 609-623

- Cowan, S. (1993), 'Regulation of several market failures: the water industry in England and Wales', Oxford Review of Economic Policy, 1993, 9(4), pp. 14-23

- Crampes, C. and A. Estache (1998), 'Regulatory trade-offs in the design of concession contracts', Utilities Policy, 7(1), pp. 1-13

- Crampes, C. and N. Fabra (2005), 'The Spanish electricity industry: Plus ça change', Energy Journal, 26(Special Issue), pp. 127-153

- Crampes, C., J-M. Glachant, C. von Hisrschhausen, F. Leveque, D. Newbery, I. Perez-Arriaga, P. Ranci, S. Stoft and B. Wilems (2009), 'Where the Champsaur Commission Has Got it Wrong', The Electricity Journal, 22(7) pp. 81-86

- Crawford, V. P. and J. Sobel (1982), 'Strategic information transmission', Econometrica, 50(6), pp. $1431-1451$

- Cremer, J. (1980), 'A partial theory of the optimal organization of a bureaucracy', Bell Journal of Economics, 11(2), pp. 683-693

- Crew, M. A. and P. R. Kleindorfer (1996), 'Incentive Regulation in the United Kingdom and the United States: Some Lessons', Journal of Regulatory Economics, 9(3), pp. 211-225

- Crew, M. A. and P. R. Kleindorfer (2002), 'Regulatory economics: Twenty years of progress?' Journal of Regulatory Economics, 21(1), pp. 5-22

- Crew, M.A. and P.R. Kleindorfer (2012), 'Regulatory economics and the journal of regulatory economics: a 30-year retrospective', Journal of Regulatory Economics, 41(1), pp. 1-18

- Cseres, K. (2008), 'What has competition done for consumers in liberalised markets?', Competition Law Review, 4(2), pp. 77-121

- Cseres, K.J. (2012), 'Consumer Protection in the European Union', in R. Van den Bergh and A.M. Pacces (eds.) 'Regulation and Economics', Encyclopedia of Law and Economics, Vol. 9, $2^{\text {nd }}$ edition, Cheltenham: Edward Elgar

- Cseres, K.J. (2013), 'Integrate or Separate-Institutional Design for the Enforcement of Competition Law and Consumer Law', Amsterdam Centre for European Law and Governance Research Paper 2013-01, Available at: http://papers.ssrn.com/sol3/papers.cfm?abstract_id=2200908

- Cubbin, J. and J. Stern (2004), 'Role of UK competition agencies in the regulation and deregulation of utility service industries', Utilities Policy, 12(2), pp. 53-55.

- Cuckierman, A. (1992), 'Central Bank Strategy, Credibility and Independence: Theory and Evidence', Cambridge, Massachusetts: MIT Press

- Dal Bo, E. (2006), 'Regulatory Capture: A Review', Oxford Review of Economic Policy, 22(2), p. 203-225. 
- Dassler, T. and D. Parker (2004), 'Harmony or Disharmony in the Regulation and the Promotion of Competition in EU Telecommunications? A Survey of the Regulatory Offices' Utilities Policy, 12(1), pp. 9-28

- Dassler, T., D. Parker and D.S. Saal (2006), 'Methods and trends of performance benchmarking in UK utility regulation', Utilities Policy, 14(3), pp. 166-174

- Dayagi-Epstein, O. (2007), 'Representation of Consumer Interest By Consumer AssociationsSalvation for the Masses?', Competition Law Review, 3(2), pp. 209-246

- Decker, C. (2013), 'The Consumer Knows Best: Involving Consumers in Regulatory Processes and Decision-making' Network, 49, December 2013, pp. 1-8

- Defeuilley, C. (2009), 'Retail competition in electricity markets', Energy Policy, 37(2), pp. 377386

- De Francesco, F., C. M. Radaelli, and V.E. Troeger (2012), 'Implementing regulatory innovations in Europe: the case of impact assessment', Journal of European Public Policy, 19(4), pp. 491-511

- De Haan, E., S. Kedia, K. Koh and S. Rajgopal (2014), 'Does the Revolving Door Affect the SEC's Enforcement Outcomes?' Working Paper, Available at: http://papers.ssrn.com/sol3/papers.cfm?abstract_id=2125560\&download=yes

- De Hauteclocque, A. (2009), 'Legal uncertainty and competition policy in European deregulated electricity markets: the case of long-term exclusive supply contracts', World Competition, 32(1), pp. 91-112

- De Hauteclocque, A. (2013), 'Market Building Through Antitrust: Long-term Contract Regulation in EU Electricity Markets', Cheltenham: Edward Elgar

- Dehousse, R. (1997), 'Regulation by networks in the European Community: the role of European agencies', Journal of European Public Policy, 4(2), pp. 246-261

- Delarue, E., L. Meeus, R. Belmans, W. D'haeseleer and J-M. Glachant (2011), 'Decarbonizing the European Electric Power Sector by 2050: A tale of three studies', European University Institute, RSCAS Working Papers No 2011/03, Available at: http://cadmus.eui.eu/bitstream/handle/1814/15485/RSCAS_2011_03.pdf?sequence=1

- DeLong, J. V. (1986), 'New Wine for a New Bottle: Judicial Review in the Regulatory State', Virginia Law Review, 72(2), pp. 399-445

- Demski, J. S. and D. E. Sappington (1987), 'Delegated expertise', Journal of Accounting Research, 25(1), pp. 68-89

- Demski, J. S. and D. E. Sappington (1987), 'Hierarchical regulatory control', RAND Journal of Economics, 18(3), pp. 369-383

- Department for Business, Innovation and Skills (BIS) (2013), 'Streamlining Regulatory and Competition Appeals: Consultation on Options for Reform', London, 19 June 2013, Available at: https://www.gov.uk/government/consultations/regulatory-and-competition-appealsoptions-for-reform

- Department for Trade and Industry (DTI) and HM Treasury (2004), 'Consumer Representation in Regulated Industries: Final Report', July 2004, Available at: www.dti.gov.uk/files/file25252.pdf

- DeShazo, J.R. and J. Freeman (2005), 'Public agencies as lobbyists' Columbia Law Review, 105(8), pp. 2217-2309

- Desmarais, B. A. and J. A. Hird (2013), 'Public policy's bibliography: The use of research in US regulatory impact analyses', Regulation \& Governance, forthcoming 
- Dessein, W. (2002), 'Authority and communication in organizations', Review of Economic Studies, 69(4), pp. 811-838

- Dessein, W., A. Galeotti, et al. (2013), 'Rational Inattention and Organizational Focus, CEPR Discussion Paper No 9395, Available at: http://www.cepr.org/pubs/dps/DP9395.asp

- de Streel, A. (2003), 'The integration of competition law principles in the new European regulatory framework for electronic communications', World Competition, 26(3), pp. 489-514

- Devenow, A. and I. Welch (1996), 'Rational herding in financial economics', European Economic Review, 40(3-5), pp. 603-615

- Dewatripont, M., I. Jewitt and J. Tirole (1999), 'The Economics of Career Concerns, Part II: Application to Missions and Accountability of Government Agencies', Review of Economic Studies, 66(1), pp. 199-217

- Dewatripont, M. and J. Tirole (1999), 'Advocates', Journal of Political Economy, 107(1), pp. 139

- Doane, M. J. and D. F. Spulber (1994), 'Open access and the evolution of the US spot market for natural gas', Journal of Law and Economics, 37(2), pp. 477-517

- Donald, S. G. and D. E. Sappington (1995), 'Explaining the choice among regulatory plans in the US telecommunications industry', Journal of Economics \& Management Strategy, 4(2), pp. 237-265

- $\quad$ Donald, S. G. and D. E. Sappington (1997), 'Choosing among regulatory options in the United States telecommunications industry', Journal of Regulatory Economics, 12(3), pp. 227-243

- Donaldson, M. and B. Kingsbury (2013), 'The Adoption of Transparency Policies in Global Governance Institutions: Justifications, Effects, and Implications', Annual Review of Law and Social Science, 9(1), pp. 119-147

- Doucet, J. and S. Littlechild (2006), 'Negotiated settlements: The development of legal and economic thinking', Utilities Policy, 14(4), pp. 266-277

- Doucet, J. and S. Littlechild (2009), 'Negotiated settlements and the National Energy Board in Canada', Energy Policy, 37(11), pp. 4633-4644

- Dreher, A., M. J. Lamla, S.M. Lein and F. Somogyi (2009), 'The impact of political leaders' profession and education on reforms', Journal of Comparative Economics, 37(1) pp. 169193Dubash, N. K. and B. Morgan (eds.) (2013), 'The Rise of the Regulatory State of the South: Infrastructure and Development in Emerging Economies', Oxford: Oxford University Press

- Dunleavy, P. and C. Hood (1994), 'From old public administration to new public management', Public Money \& Management, 14(3), pp. 9-16

- Dunlop, C. A., M. Maggetti, C.M. Radaelli and D. Russel (2012), 'The many uses of regulatory impact assessment: A meta-analysis of EU and UK cases', Regulation \& Governance, 6(1), pp. 23-45

- Duprat, J.-P. (2012), 'The Judicial Review of Ex Ante Impact Assessment in France: An Attempt to Fuse the Principles of Legal Certainty and Institutional Balance', Legisprudence, 6(3), pp. 379-396

- Dur, R. and O. H. Swank (2005), 'Producing and Manipulating Information', Economic Journal, 115(500), pp. 185-199

- Earl, P., L. Friesen and K. Hatherley (2011), 'Bounded Rationality and Consumer Research: Lessons From a Study of Choices of Mobile Phone Service Contracts', University of Queensland, School of Economics, Discussion Papers Series No 449, http://www.uq.edu.au/economics/abstract/449.pdf 
- Eberlein, B. and E. Grande (2000), 'Regulation and Infrastructure Management: German Regulatory Regimes and the EU Framework', German Policy Studies/Politikfeldanalyse, 1(1), pp. 39-66

- Eberlein, B. and E. Grande (2005), 'Beyond delegation: transnational regulatory regimes and the EU regulatory state', Journal of European Public Policy, 12(1), pp. 89-112

- Eberlein, B. and Newman, A. (2008), 'Escaping the International Governance Dilemma? Incorporated Transgovernmental Networks in the European Union', Governance, 21(1), pp. 25-52

- Eckert, R. D. (1981), 'Life Cycle of Regulatory Commissioners', Journal of Law and Economics, 24(1), pp. 113-120

- Edwards, G. and L. Waverman (2006), 'The effects of public ownership and regulatory independence on regulatory outcomes', Journal of Regulatory Economics, 29(1), pp. 23-67

- Egeberg, M. and J. Trondal (2009), 'National Agencies in the European Administrative Space: Government Driven, Commission Driven or Networked?', Public Administration, 87(4), pp. 779-790

- Ek, K. and P. Söderholm (2008), 'Households' switching behavior between electricity suppliers in Sweden', Utilities Policy, 16(4), pp. 254-261

- Elhauge, E. R. (1991), 'Does interest group theory justify more intrusive judicial review?', Yale Law Journal, 101(1), pp. 31-110

- Epstein, D. and S. O'Halloran (1994), 'Administrative Procedures, Information, and Agency Discretion', American Journal of Political Science, 38(3), pp. 697-722

- Erdogdu, E. (2013) 'A cross-country analysis of electricity market reforms: Potential contribution of New Institutional Economics', Energy Economics, 39, pp. 239-251

- Erta, K., S. Hunt, Z. Iscenko and W. Brambley (2013), 'Applying behavioural economics at the Financial Conduct Authority', Financial Conduct Authority, Occasional Paper No. 1, April 2013, Available at: http://www.fca.org.uk/your-fca/documents/occasional-papers/occasionalpaper-1

- Eskridge, W.N. and J. Ferejohn (1992), 'Making the Deal Stick: Enforcing the Original Constitutional Structure of Lawmaking in the Modern Regulatory State', Journal of Law, Economics, \& Organization, 8(1), pp. 165-189

- Essens, O., A. Gerbrandy and S.A.C.M. Lavrijssens-Heijmans (2009), 'National Courts and the Standard of Review in Competition Law and Economic Regulation', Volume 1, European administrative law series, Europa Law Publishing

- Estache, A., M.A. Rossi, and C.A. Ruzzier (2004),' The Case for International Coordination of Electricity Regulation: Evidence from the Measurement of Efficiency in South America', Journal of Regulatory Economics, 25(3), pp. 271-295

- Estache, A., A. Goicoechea and M. Manacorda (2006), 'Telecommunications performance, reforms, and governance, World Bank Policy Research Working Paper No. 3822, Available at: http://www-wds.worldbank.org/servlet/WDSContentSer ... ered/PDF/wps3822.pdf

- Estache, A. and L. Wren-Lewis (2011), 'Anti-corruption policy in theories of sector regulation', Chapter 9 in S. Rose-Ackerman and T. Soreide (eds.) 'International Handbook on the Economics of Corruption, Volume 2', pp. 269-299

- Estache, A. and L. Wren-Lewis (2012), 'Supranational Infrastructure Regulation: Institutional Opportunities and Challenges', ECARES Working Paper 2012-025, Available at: https://dipot.ulb.ac.be/dspace/bitstream/2013/1249 ... IS-supranational.pdf 
- Esty, D. C. (2006), 'Good Governance at the Supranational Scale: Globalizing Administrative Law', The Yale Law Journal, 115(7), pp. 1490-1562

- European Commission (2010), 'The functioning of retail electricity markets for consumers in Europe', Commission Staff Working Paper, SEC(2010) 1409 final, Brussels

- European Commission (2012), 'Making the internal energy market work', Communication from the Commission to the European Parliament, the Council, the European Economic and

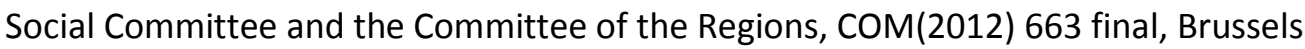

- European Regulators Group (2009), 'Report on Transparency of Tariff Information', ERG(08) 59rev2, March 2009, Available at: http://www.irg.eu/template20.jsp?categoryld=260354\& contentld=545849

- Evans, J., P. Levine and F. Trillas (2008), 'Lobbies, delegation and the under-investment problem in regulation', International Journal of Industrial Organization, 26(1), pp. 17-40

- Evans, J., P. Levine, N. Rickman and F. Trillas (2011), 'Delegation to Independent Regulators and the Ratchet Effect', University of Surrey, School of Economics Discussion Papers No 911, Available at: http://www.fahs.surrey.ac.uk/economics/discussion_papers/2011/DP09-11.pdf

- Fabrizio, K.R. (2013), 'The Effect of Regulatory Uncertainty on Investment: Evidence from Renewable Energy Generation', Journal of Law, Economics, and Organization, 29(4), pp. 765798

- Fainsod, M. (1940), 'Some reflections on the nature of the regulatory process', Public Policy, 1, pp. 297-323

- Farrell, J. (1997), 'Prospects for Deregulation in Telecommunications', Industrial and Corporate Change, 6(4), pp. 719-740

- Faure-Grimaud, A. and D. Martimort (2003), 'Regulatory Inertia', RAND Journal of Economics, 34(3), pp. 413-437

- Ferejohn, J. and C. Shipan (1990), 'Congressional influence on bureaucracy', Journal of Law, Economics, \& Organization, 6(Special Issue), pp. 1-20

- Field, C. (2007), 'Interacting with Consumer Advocates', Australian Journal of Public Administration, 66(1), pp. 96-103

- Financial Services Authority (2008), 'Consumer responsibility', FSA Discussion Paper 08/5, December 2008, Available at: www.fsa.gov.uk/pubs/discussion/dp08_05.pdf

- Finger, M. and F. Varone (2006), 'Governance of network industries: towards European regulators, differentiated regulations, or self-regulation?' CDM Working Papers Series MIRREPORT-2006-008

- Finsinger, J. and I. Vogelsang (1981), 'Alternative Institutional Frameworks for Price Incentive Mechanism', Kyklos, 34(3), pp. 388-404

- Flores, M. and C. Waddams Price (2013), 'Consumer behaviour in the British retail electricity market', Centre for Competition Policy, Working Paper 13-10, Available at: http://competitionpolicy.ac.uk/publications/working-papers-2013

- Follesdal, A. and S. Hix (2006), 'Why There is a Democratic Deficit in the EU: A Response to Majone and Moravcsik', Journal of Common Market Studies, 44(3), pp. 533-562

- Franceys, R. W. and E. Gerlach (2011), 'Consumer involvement in water services regulation', Utilities Policy, 19(2), pp. 61-70

- Freeman, R. B. (2000), 'Single Peaked vs. Diversified Capitalism: The Relation Between Economic Institutions and Outcomes', NBER Working Papers No 7556, Available at: http://www.nber.org/papers/w7556.pdf 
- Fremeth, A. and G. L. Holburn (2009), 'Information Asymmetries and Regulatory Rate-Making: Case Studies from Commonwealth Edison and Duke Energy', Chapter 12 in C. Menard and M. Ghertman (eds.) 'Regulation, Deregulation, Reregulation: Institutional Perspectives', Cheltenham: Edward Elgar

- Fremeth, A. R. and G. L. Holburn (2012), 'Information Asymmetries and Regulatory Decision Costs: An Analysis of US Electric Utility Rate Changes 1980-2000', Journal of Law, Economics, and Organization, 28(1), pp. 127-162

- Fritsch, O., Radaelli, C.M., Schrefler, L. and Renda, A. (2013), 'Comparing the content of regulatory impact assessments in the UK and the EU', Public Money \& Management, 33(6), pp. 445-452

- Ganuza, J-J. and E. Hauk (2004), 'Economic integration and corruption', International Journal of Industrial Organization, 22(10), pp. 1463-1484

- Garrod, L., M. Hviid, G. Loomes and C. Waddams Price (2008), 'Assessing the effectiveness of potential remedies in consumer markets', Office of Fair Trading OFT 994, April 2008, Available at: www.oft.gov.uk/shared_oft/economic_research/oft994.pdf

- Garside, L., P. Grout, and A. Zalewska (2008), 'Do investigated companies manipulate profitability data?', Working Paper

- Garside, L., P. A. Grout and A. Zalewska (2013), 'Does Experience Make You 'Tougher'? Evidence From Competition Law', Economic Journal, 123(568), pp. 474-490

- Gaudeul, A. and R. Sugden (2012), 'Spurious Complexity and Common Standards in Markets for Consumer Goods', Economica, 79(314), pp. 209-225

- Gentzkow, M. and E. Kamenica (2011), 'Competition in Persuasion', NBER Working Paper No. 17436, Available at: http://www.nber.org/papers/w17436

- Geradin, D. (2004a), 'Development of European Regulatory Agencies: What the EU Should Learn from American Experience', Columbia Journal of European Law, 11, pp. 1-52

- Géradin, D. (ed.) (2004b), 'Remedies in Network Industries: EC Competition Law Versus Sector-specific Regulation', Antwerp: Intersentia

- Geradin, D. and M. Kerf (2003), 'Controlling Market Power in Telecommunications: Antitrust vs Sector-Specific Regulation', Oxford: Oxford University Press

- Gerardi, D. and L. Yariv (2008), 'Costly Expertise', American Economic Review, pp. 187-193

- Gifford, R. L. (2003), 'Regulatory Impressionism: What Regulators Can and Cannot Do', Review of Network Economics, 2(4)

- Gilardi, F. (2002), 'Policy credibility and delegation to independent regulatory agencies: a comparative empirical analysis', Journal of European Public Policy, 9(6), pp. 873-893

- Gilardi, F. (2005), 'The Institutional Foundations of Regulatory Capitalism: The Diffusion of Independent Regulatory Agencies in Western Europe', The Annals of the American Academy of Political and Social Science, 598(1), pp. 84-101.

- Gilardi, F. (2008), 'Delegation in the Regulatory State: Independent Regulatory Agencies in Western Europe', Cheltenham: Edward Elgar

- Gilbert, R. and D. Newbery (2008), 'Analytical Screens for Electricity Mergers', Review of Industrial Organization, 32(3-4), pp. 217-239

- Giulietti, M., C. Waddams Price and M. Waterson (2005), 'Consumer Choice and Competition Policy: a Study of UK Energy Markets', Economic Journal, 115(506), pp. 949-968

- Giulietti, M., M. Waterson and M.R. Wildenbeest (2014), 'Estimation of search friction in the UK electricity market', Journal of Industrial Economics, forthcoming 
- Glachant, J-M. (1998), 'England's wholesale electricity market: could this hybrid institutional arrangement be transposed to the European Union?', Utilities Policy, 7(2), pp. 63-74

- Glachant, J-M. (2011), 'A vision for the EU gas target model: The MECO-S model', European University Institute RSCAS Working Papers No 2011/38, Available at: http://cadmus.eui.eu/bitstream/handle/1814/17974/R ... ev\%5d.pdf?sequence=3

- Glachant, J-M., F. Lévêque, and P. Ranci (2008a), 'Some Guideposts on the Road to Formulating a Coherent Policy on EU Energy Security of Supply', The Electricity Journal, 21(10), pp. 13-18

- Glachant, J-M., U. Dubois and Y. Perez (2008b), 'Deregulating with no regulator: Is the German electricity transmission regime institutionally correct?', Energy Policy, 36(5), pp. 16001610Glachant, J-M. and F. Lévêque (2009), 'Electricity Reform in Europe: Towards A Single Energy Market, Cheltenham: Edward Elgar

- Glachant, J-M., H. Khalfallah, Y. Perez, V. Rious and M. Saguan (2013), 'Implementing incentive regulation through an alignment with resource bounded regulators', Competition and Regulation in Network Industries, pp. 265-291

- Glaeser, E., S. Johnson and A. Shleifer (2001), 'Coase versus the Coasians', Quarterly Journal of Economics, 116(3), pp. 853-899

- Glaeser, E.L. and A. Shleifer (2003), 'The Rise of the Regulatory State', Journal of Economic Literature, 41(2), pp. 401-425

- Gormley Jr, W. T. (1981), 'Statewide Remedies for Public Underrepresentation in Regulatory Proceedings', Public Administration Review, July-August, pp. 454-462

- Gormley, W., J. Hoadley and C. Williams (1983), 'Potential Responsiveness in the Bureaucracy: Views of Public Utility Regulation', American Political Science Review, pp. 704-717

- Graham, C. (1995), 'Is There a Crisis in Regulatory Accountability?', Centre for the Study of Regulated Industries (CRI)

- Graham, C. (2006), 'The politics of necessity: electricity and water in Great Britain', Journal of Consumer Policy, 29(4), pp. 435-448

- Green, R. (1991), 'Reshaping the CEGB: Electricity privatization in the UK', Utilities Policy, 1(3), pp. 245-254

- Green, R.J. (2008), 'Electricity Wholesale Markets: Designs Now and in a Low-carbon Future', The Energy Journal, 29(Special Issue), pp. 95-124

- Green, R. and D. M. Newbery (1997), 'Competition in the electricity industry in England and Wales', Oxford Review of Economic Policy, 13(1), pp. 27-46

- Green, R. and T. McDaniel (1998), 'Competition in Electricity Supply: Will '1998' Be Worth It?" Fiscal Studies, 19(3), pp. 273-293

- Green, R. and J. Haskel (2004), 'Seeking a Premier-League Economy: The Role of Privatization', Chapter 2 in D. Card, R. Blundell and R.B. Freeman (eds.) 'Seeking a Premier Economy: The Economic Effects of British Economic Reforms, 1980-2000', Chicago: University of Chicago Press, pp. 63-108

- Green, R., A. Lorenzoni, Y. Perez and M. Pollitt (2009), 'Policy assessment and good practices', Chapter 7 in J-M. Glachant and F. Leveque, 'Electricity Reform in Europe: Towards a Single Energy Market, Cheltenham: Edward Elgar, pp. 172-206

- Green, R., B. Hobbs, S. Oren and A. Siddiqui (2010), 'Policymaking benefits and limitations from using financial methods and modelling in electricity markets', Energy Economics, 32(4), pp. 749-750. 
- Greenstein, S. (1993), 'Procedural rules and procurement regulations: Complexity creates trade-offs', Journal of Law, Economics, \& Organization, 9(1), pp. 159-180

- Greenwood, P. J. (2011), 'Interest Representation in the European Union', $3^{\text {rd }}$ Edition, Basingstoke: Palgrave Macmillan

- Grout, P., A. Jenkins and A. Zalewska (2012), 'Regulatory Valuation of Public Utilities: A Case Study of the 20th Century', Working Paper, Available at: http://papers.ssrn.com/sol3/papers.cfm?abstract_id=2205955

- Growitsch, C., T. Jamasb and M. Pollitt (2009), 'Quality of service, efficiency and scale in network industries: an analysis of European electricity distribution', Applied Economics, 41(20), pp. 2555-2570

- Growitsch, C., T. Jamasb, C. Muller and M. Wissner (2010), 'Social cost-efficient service quality-Integrating customer valuation in incentive regulation: Evidence from the case of Norway', Energy Policy, 38(5), pp. 2536-2544

- Gual, J. and F. Trillas (2006), 'Telecommunications Policies: Measurement and Determinants', Review of Network Economics, 5(2)

- Guerriero, C. (2012), 'The political economy of (de) regulation: Theory and evidence from the US electricity market', Working Paper, Available at: http://papers.ssrn.com/sol3/papers.cfm?abstract_id=1641098

- Gupta, A. (2013), 'Estimating Direct Gains in Consumer Welfare in Telecommunications Sector', Journal of Consumer Policy, 36(2), pp. 119-138

- Guthrie, G. (2006), 'Regulating Infrastructure: The Impact on Risk and Investment." Journal of Economic Literature, 44(4), pp. 925-972

- Gutiérrez, L. H. (2003a), 'Regulatory governance in the Latin American telecommunications sector', Utilities Policy, 11(4), pp. 225-240

- Gutiérrez, L. H. (2003b), 'The effect of endogenous regulation on telecommunications expansion and efficiency in Latin America', Journal of Regulatory Economics, 23(3), pp. 257286

- Haas, P. M. (1992), 'Introduction: epistemic communities and international policy coordination', International Organization, 46(01), pp. 1-35

- Hahn, R.W. and R.E. Litan (2005), 'Counting regulatory benefits and costs: Lessons for the US and Europe', Journal of International Economic Law, 8(2), pp. 473-508

- Hampton, P. (2005), 'Reducing administrative burdens: effective inspection and enforcement', London: HM Treasury, Available at: www.bis.gov.uk/files/file22988.pdf

- Hancher, L. and M. Moran (1989), 'Organizing regulatory space', Chapter 10 in Hancher, L. and M. Moran (eds.) 'Capitalism, Culture and Regulation, Oxford: Oxford University Press, pp. 272300

- Hancher, L., P. Larouche, and S. Lavrijssen (2003), 'Principles of good market governance', Competition and Regulation in Network Industries, 4(4), pp. 355-

- Hancher, L. and P. Larouche (2010),' The coming of age of EU regulation of network industries and services of general economic interest', Tilburg University Discussion Paper No 2010-024, Available at: http://papers.ssrn.com/sol3/papers.cfm?abstract_id=1628573Haney, A. B. and M. G. Pollitt (2011), 'Exploring the determinants of "best practice" benchmarking in electricity network regulation', Energy Policy, 39(12), pp. 7739-7746

- Hanretty, C. (2013), 'Independent regulators versus the Rogowski-Kayser effect on consumer prices', Presentation at Centre for Competition Policy, University of East Anglia 
- Hanretty, C. and C. Koop (2012), 'Measuring the formal independence of regulatory agencies', Journal of European Public Policy, 19(2), pp. 198-216

- Hanretty, C., P. Larouche and A.P. Reindl (2012), 'Independence, Accountability and Perceived Quality of Regulators', Centre for Regulation in Europe, Brussels

- Hanretty, C. and C. Koop (2013), 'Shall the law set them free? The formal and actual independence of regulatory agencies', Regulation \& Governance, 7(2), pp. 195-214

- Harker, M. (2005), 'UK Utility Regulation: Licences, Commitment and Judicial Review', Annals of Public and Cooperative Economics, 76(1), pp. 5-33

- Harker, M., A. Kreutzmann and C. Waddams (2013), 'Public service obligations and competition: Final report', CERRE Study, Brussels, Available at: http://www.cerre.eu/publications/public-service-obligations-and-competition

- Harrington, W. and R.D. Morgenstern (2004), 'Evaluating Regulatory Impact Analyses', Resources for the Future, Washington, DC, Discussion Paper 04-04

- Hausman, J. A. and J. G. Sidak (2004), 'Why Do the Poor and the Less-Educated Pay More for Long-Distance Calls', The B.E. Journal of Economic Analysis \& Policy, 3(1), pp. 1-29

- Hausman, J. A. and W. E. Taylor (2013), 'Telecommunication in the US: From Regulation to Competition (Almost)', Review of Industrial Organization, 42(2), pp. 203-230

- Hausman, J. and J. G. Sidak (2014), 'Telecommunications Regulation: Current Approaches with the End in Sight', Chapter 6 in N.L. Rose (ed.) 'Economic Regulation and Its Reform: What Have We Learned?', Chicago: University of Chicago PressHelland, E. and J. Klick (2012). 'Why Aren't Regulation and Litigation Substitutes?: An Examination of the Capture Hypothesis' Chapter 11 in C. Coglianese (ed.) 'Regulatory Breakdown: The Crisis of Confidence in US Regulation', Philadelphia: University of Pennsylvania Press, pp. 227-244

- Helm, D. (2001), 'The Assessment: European Networks - Competition, Interconnection, and Regulation', Oxford Review of Economic Policy, 17(3), pp. 297-312

- Helm, D. A. and T. Jenkinson (eds.) (1998), 'Competition in Regulated Industries', Oxford: Oxford University Press

- Henisz, W. J., G. L. F. Holburn and B. A. Zelner (2005), 'Deinstitutionalization and Institutional Replacement: State-Centered and Neo-Liberal Models in the Global Electricity Supply Industry', World Bank Policy Research Working Paper No. 3690, Available at: http://papers.ssrn.com/sol3/papers.cfm?abstract_id=801446

- Henisz, W. J. and B. A. Zelner (2006), 'Interest Groups, Veto Points, and Electricity Infrastructure Deployment', International Organization, 60(1), pp. 263-286

- Héritier, A. (2001), 'Market integration and social cohesion: the politics of public services in European regulation', Journal of European Public Policy, 8(5), pp. 825-852

- Héritier, A. (2002), 'Public-interest services revisited', Journal of European Public Policy, 9(6), pp. 995-1019

- Hertogh, M. and S. Halliday (eds.) (2004), 'Judicial Review and Bureaucratic Impact: International and Interdisciplinary Perspectives, Cambridge Studies in Law and Society, Cambridge: Cambridge University Press

- Hilson, C. (2003), 'The Europeanization of English Administrative Law: Judicial Review and Convergence', European Public Law, 9(1), pp. 125-145

- Hlásny, V. (2011), 'Economic determinants of deregulation in the gas distribution market', Journal of Economic Policy Reform, 14(3), pp. 201-213

- Hlasny, V. (2013), 'Commissioner Selection and Deregulation of Gas Utilities', Available at: http://papers.ssrn.com/sol3/papers.cfm?abstract_id=2029542 
- Hogan, W. W. (2002), 'Electricity market restructuring: reforms of reforms', Journal of Regulatory Economics, 21(1), pp. 103-132

- Holburn, G. L. and P. T. Spiller (2002a), 'Institutional or structural: lessons from international electricity sector reforms', Chapter 25 in E. Brousseau and J-M. Glachant (eds.) 'The Economics of Contracts: Theories and Applications', Cambridge: Cambridge University Press, pp. 463-502

- Holburn, G. L. and P. T. Spiller (2002b), 'Interest Group Representation in Administrative Institutions: The Impact of Consumer Advocates and Elected Commissioners on Regulatory Policy in the United States', UCEI Working Paper, Energy Policy and Economics 002, Available at: http://escholarship.org/uc/item/5cg3d8q0

- Holburn, G. L. and R. G. V. Bergh (2004), 'Influencing Agencies Through Pivotal Political Institutions', Journal of Law, Economics, and Organization, 20(2), pp. 458-483

- Holburn, G.L. and R.G.V. Bergh (2006), 'Consumer capture of regulatory institutions: The creation of public utility consumer advocates in the United States'. Public Choice, 126(1-2), pp. 45-73

- Holburn, G. L. and R. G. V. Bergh (2008), 'Making friends in hostile environments: Political strategy in regulated industries', Academy of Management Review, 33(2), pp. 521-540

- Holburn, G. L. and P. T. Spiller (2002b), 'Interest Group Representation in Administrative Institutions: The Impact of Consumer Advocates and Elected Commissioners on Regulatory Policy in the United States', UCEI Working Paper, Energy Policy and Economics 002, Available at: http://escholarship.org/uc/item/5cg3d8q0

- Holburn, G. L. and B. A. Zelner (2010), 'Political capabilities, policy risk, and international investment strategy: Evidence from the global electric power generation industry', Strategic Management Journal, 31(12), pp. 1290-1315

- Holmstrom, B. and P. Milgrom (1991), 'Multitask principal-agent analyses: Incentive contracts, asset ownership, and job design', Journal of Law Economics and Organization, 7(Special Issue), pp. 24-52

- Hong, H., J. D. Kubik and A. Solomon (2000), 'Security analysts' career concerns and herding of earnings forecasts', RAND Journal of Economics, 31(1), pp. 121-144

- Hood, C. (1995), 'The "new public management" in the 1980s: Variations on a theme', Accounting, Organizations and Society, 20(2-3), pp. 93-109

- Hood, C. and C. Scott (1996), 'Bureaucratic Regulation and New Public Management in the United Kingdom: Mirror-Image Developments?, Journal of Law and Society, 23(3), pp. 321345

- Hortaçsu, A., S. A. Madanizadeh, and S. L. Puller (2012), 'Power to choose? an analysis of choice frictions in the residential electricity market', Working paper

- House of Lords (2004), 'The Regulatory State: Ensuring its Accountability', Volume 1: Report, Select Committee on the Constitution, $6^{\text {th }}$ Report of Session 2003-04, London: The Stationary Office

- Howarth, D. (2008), 'Internal Policies: The Commission Defends the EU Consumer', Journal of Common Market Studies, 46(s1), pp. 91-107

- Huck, S. and J. Zhou (2011), 'Consumer behavioural biases in competition: A survey', Office of Fair Trading, OFT1324, Available at: http://mpra.ub.uni-muenchen.de/31794/

- Hudson, C. and J. Hudson (2008), 'Guaranteeing quality in the EU: who gains most?', Journal of Regulatory Economic, 33(3), pp. 283-298

- Humphreys, P. and S. Padgett (2006), 'Globalization, the European Union, and Domestic Governance in Telecoms and Electricity', Governance, 19(3), pp. 383-406 
- Hyman, D. A. and W. E. Kovacic (2013), 'Institutional Design, Agency Life Cycle, and the Goals of Competition Law', Fordham Law Review, 81, pp. 2163-2987

- Ingold, K., F. Varone and F. Stokman (2013), 'A social network-based approach to assess de facto independence of regulatory agencies', Journal of European Public Policy, 20(10), pp. 1464-1481

- Ipsos-MORI (2012), 'Customer Engagement with the Energy Market-Tracking Survey 2012', Report prepared for Ofgem, 12 April 2012

- Jackson, T. (2005), 'Can We (Should We) Regulate 'Cultures of Consumption?' in P. Vass (ed.) Regulatory Review 2004/2005, Centre for the study of Regulated Industries, University of Bath, pp. 143-170, Available at: http://www.bath.ac.uk/management/cri/publications/regulatory_reviews.html

- Jamasb, T. and M. Pollitt (2000), 'Benchmarking and regulation: international electricity experience', Utilities Policy, 9(3), pp. 107-130

- Jamasb, T., P. Nillesen and M. Pollitt (2003), 'Gaming the Regulator: A Survey', The Electricity Journal, 16(10), pp. 68-80

- Jamasb, T. and M. Pollitt (2003), 'International benchmarking and regulation: an application to European electricity distribution utilities', Energy Policy, 31(15), pp. 1609-1622

- Jamasb, T., P. Nillesen, and M. Pollitt (2004), 'Strategic behaviour under regulatory benchmarking', Energy Economics, 26(5), pp. 825-843

- Jamasb, T. and M.G. Pollitt (2005), 'Electricity Market Reform in the European Union: Review of Progress towards Liberalisation and Integration', Energy Journal, European Energy Liberalisation Special Issue, pp. 11-41

- Jayasuriya, K. (2001), 'Globalization and the changing architecture of the state: the regulatory state and the politics of negative co-ordination', Journal of European Public Policy, 8(1), pp. 101-123

- Jensen, M. C. and W. H. Meckling (1995), 'Specific and general knowledge, and organizational structure', Journal of Applied Corporate Finance, 8(2), pp. 4-18

- Jones, C. and J.-M. Glachant (2010), 'Toward a Zero-Carbon Energy Policy in Europe: Defining a Viable Solution', The Electricity Journal, 23(3), pp. 15-25

- Jordana, J. and D. Levi-Faur (eds.) (2004), 'The Politics of Regulation: Institutions and Regulatory Reforms for the Age of Governance', Cheltenham: Edward Elgar

- Jordana, J. and D. Levi-Faur (2007), 'Professional networks, institutional design and global governance', Économie international, 109, pp. 83-106

- Jordana, J., D. Levi-Faur and X. F. I Marin (2011), 'The Global Diffusion of Regulatory Agencies: Channels of Transfer and Stages of Diffusion', Comparative Political Studies, 44(10), pp. 13431369

- Joskow, P.L. (1972), 'The determination of the allowed rate of return in a formal regulatory hearing', Bell Journal of Economics and Management Science, 3(2), pp. 632-644

- Joskow, P.L. (1974), 'Inflation and Environmental Concern: Structural Change in the Process of Public Utility Price Regulation', Journal of Law and Economics, 17(2), pp. 291-327

- Joskow, P. L. (1996a), 'Introducing Competition into Regulated Network Industries: from Hierarchies to Markets in Electricity', Industrial and Corporate Change, 5(2), pp. 341-382

- Joskow, P. L. (1996b), 'How will it all end? the electric utility industry in 2005', The Electricity Journal, 9(1), pp. 67-73

- Joskow, P. L. (1997), 'Restructuring, competition and regulatory reform in the US electricity sector', Journal of Economic Perspectives, 11(3), pp. 119-138 
- Joskow, P.L. (2001), 'California's Electricity Crisis', Oxford Review of Economic Policy, 17(3), pp. 365-388

- Joskow, P. L. (2003), 'Energy policies and their consequences after 25 years', Energy Journal, 24(4), pp. 17-49

- Joskow, P. L. (2005), 'Regulation and deregulation after 25 years: Lessons learned for research in industrial organization', Review of Industrial Organization, 26(2), pp. 169-193

- Joskow, P. (2008), 'Lessons learned from electricity market liberalization', Energy Journal 29(Special Issue), pp. 9-42

- Joskow, P.L. (2014), 'Incentive Regulation in Theory and Practice: Electricity Distribution and Transmission Networks', Chapter 5 in N.L. Rose (ed.) 'Economic Regulation and Its Reform: What Have We Learned?', Chicago: University of Chicago Press

- Joskow, P. L. and N. L. Rose (1989), 'The effects of economic regulation', Chapter 25 in R. Schmalensee and R. Willig (eds.) 'Handbook of Industrial Organization, Volume 2', Amsterdam: Elsevier, pp. 1449-1506

- Juliusson, E. A., A. Gamble and T. Gärling (2007), 'Loss aversion and price volatility as determinants of attitude towards and preference for variable price in the Swedish electricity market', Energy Policy, 35(11), pp. 5953-5957

- Kagan, R. A. (1997), 'Should Europe Worry about Adversarial Legalism?', Oxford Journal of Legal Studies, 17(2), pp. 165-183

- Kagan, R. A. (2001), 'Adversarial Legalism: The American Way of Law', Cambridge, MA: Harvard University Press

- Kagan, R. A. (2006), 'American and European Ways of Law: Six Entrenched Differences', Institute of European Studies, Working Paper, Available at: http://www.escholarship.org/uc/item/3kt912b3.pdf;origin=repeccitec

- Kagan, R. A. (2007), 'Globalization and legal change: The "Americanization” of European law?, Regulation \& Governance, 1(2), pp. 99-120

- Kahn, A. E. (2002), 'The deregulatory tar baby: The precarious balance between regulation and deregulation, 1970-2000 and henceforward', Journal of Regulatory Economics, 21(1), pp. 3556

- Kawamura, K. (2011), 'A Model of Public Consultation: Why is Binary Communication so Common?', Economic Journal, 121(553), pp. 819-842

- Kay, J. (1996), 'Regulating private utilities: The customer corporation', Journal of Co-operative Studies, 87, pp. 28-46

- Kelemen, D. R. (2006), 'Suing for Europe: Adversarial Legalism and European Governance', Comparative Political Studies, 39(1), pp. 101-127

- Kelemen, R. D. (2011), 'Eurolegalism: the transformation of law and regulation in the European Union', Cambridge, MA: Harvard University Press

- Kingsbury, B., N. Krisch and R. B. Stewart (2005), 'The Emergence of Global Administrative Law', Law and Contemporary Problems, 68(3/4), pp. 15-61

- Kingsbury, B. and R. B. Stewart (2008), 'Legitimacy and accountability in global regulatory governance: The emerging global administrative law and the design and operation of administrative tribunals of international organizations', Chapter 1 in K. Papanikolaou (ed.), 'International Administrative Tribunals in a Changing World', New York: Esperia Publications, pp. 1-20

- Kleit, A. N., A. V. Shcherbakova and X. Chen (2012), 'Restructuring and the retail residential market for power in Pennsylvania', Energy Policy, 46, pp. 443-451 
- Kohler-Koch, B. and B. Rittberger (2006), 'Review Article: The 'Governance Turn' in EU Studies, Journal of Common Market Studies, 44(s1), pp. 27-49

- Koray, S. and I. Saglam (2005), 'The Need for Regulating a Bayesian Regulator', Journal of Regulatory Economics, 28(1), pp. 5-21

- Korkea-Aho, E. (2012), 'Better Judicial Review? EU Courts and the Smart Regulation Agenda in Implementing Chemicals Regulation', Legisprudence, 6(3), pp. 397-423

- Kovacic, W. E. (1994), 'Post-Appointment Preference Shaping and Its Influence on Judicial Analysis of Economic Regulation Issues', Chapter 6 in M. A. Crew and P. R. Kleindorfer (eds.) 'Commercialization of Postal and Delivery Services: National and International Perspectives', Topics in Regulatory Economics and Policy, Volume 19, Springer, pp. 93-108

- Kovacic, W. E. (1995), 'Accounting for regulation in determining the application of antitrust rules to firms subject to public utility oversight', Antitrust Bulletin, 40(3), pp. 483-499

- Kovacic, W.E. (1997), 'Quality of Appointments and the Capability of the Federal Trade Commission', Administrative Law Review, 49(4), pp. 915-948

- Kovacic, W.E. (2002), 'Economic Regulation and the Courts 1982 to 2001: Ten Cases That Made a Difference', Journal of Regulatory Economics, 21(1), pp. 23-34

- Kovacic, W.E. (2010), 'The Digital Broadband Migration and the Federal Trade Commission: Building the Competition and Consumer Protection Agency of the Future', Journal of Telecommunications and High Technology Law, 8(1), pp. 1-24

- Kridel, D. J., D. E. Sappington and D. E. Weisman (1996), 'The effects of incentive regulation in the telecommunications industry: A survey', Journal of Regulatory Economics, 9(3), pp. 269306

- Krishna, V. and J. Morgan (2001), 'A model of expertise', Quarterly Journal of Economics, 116(2), pp. 747-775

- Küpper, G., E. Delarue, B. Delvaux, L. Meeus, D. Bekaert, B. Willems, S. Proost, W. D'haeseleer, K. Deketelaere and R. Belmans (2009), 'Does More International Transmission Capacity Increase Competition in the Belgian Electricity Market?', The Electricity Journal, 22(1), pp. 2136

- Kwoka Jr, J. E. (2002), 'Governance Alternatives and Pricing in the US Electric Power Industry', Journal of Law, Economics, and Organization, 18(1), pp. 278-294Laffont, J.-J. and J. Tirole (1993), 'A Theory of Incentives in Procurement and Regulation', Cambridge, MA: MIT Press

- Laffont, J-J. and D. Martimort (1998), 'Transaction costs, institutional design and the separation of powers', European Economic Review, 42(3-5), pp. 673-684

- Laffont, J-J. and D. Martimort (1999), 'Separation of regulators against collusive behavior', RAND Journal of Economics, pp. 232-262

- Laffont, J-J. and J. Pouyet (2004), 'The subsidiarity bias in regulation', Journal of Public Economics, 88(1-2), pp. 255-283Lambrecht, A. and B. Skiera (2006), 'Paying Too Much and Being Happy About It: Existence, Causes and Consequences of Tariff-Choice Biases', Journal of Marketing Research, 43(2), pp. 212-223.

- La Porta, R., F. López de Silanes, and A. Shleifer (2008), 'The Economic Consequences of Legal Origins', Journal of Economic Literature, 46(2), pp. 285-332

- Larouche, P. (2004), 'Coordination of European and Member State Regulatory PolicyHorizontal, Vertical and Transversal Aspects', Competition and Regulation in Network Industries, 5(3), p. 277-294 
- Larouche, P. (2006), 'Contrasting Legal Solutions and the Comparability of EU and US Experiences', TILEC Discussion Paper No. 2006-028, Available at: http://papers.ssrn.com/sol3/papers.cfm?abstract_id=943615

- Larouche, P. and M. De Visser (2006), 'The triangular relationship between the commission, NRAs and national courts revisited', Communications \& Strategies, 64, pp. 125-145

- Larouche, P. and X. Taton (2011), 'Enforcement and judicial review of decisions of national regulatory authorities', CERRE Study, Available at: http://papers.ssrn.com/sol3/papers.cfm?abstract_id $=2063747$

- Larsen, A., L. H. Pedersen, E. M. Sorensen and O. J. Olsen (2006), 'Independent regulatory authorities in European electricity markets' Energy Policy, 34(17), pp. 2858-2870

- Laufer, J., B. MacDonald, B. Pike and M. Zhou (2013), 'Community Choice Aggregation: Municipal Bulk Buying of Electricity in Massachusetts', Tufts University Field Projects Team 7, Available at: ase.tufts.edu/uep/degrees/field.../Team_7_Final_Report_2013.pdf

- Lavrijssen, S. A. C. M. (2014), 'The Different Faces of Energy Consumers: Toward a Behavioural Economics Approach', Journal of Competition Law and Economics, 20(2), pp. 257-291

- Law, M. T. and C. X. Long (2011), 'Revolving door laws and state public utility commissioners', Regulation \& Governance, 5(4), pp. 405-424

- Law, M.T. and C.X. Long (2012), 'What Do Revolving-Door Laws Do?' Journal of Law and Economics, 55(2), pp. 421-436

- Léautier, T-O. (2012), 'Is Mandating 'Smart Meters' Smart?', TSE Working Papers No 12-341, Available at: http://www.tse-fr.eu/images/doc/wp/io/wp_tse_341.pdf

- Leaver, C. (2009), 'Bureaucratic Minimal Squawk Behavior: Theory and Evidence from Regulatory Agencies', American Economic Review, pp. 572-607

- Lee, J. (2013), 'The Administrative Broker: Bureaucratic Politics in the Era of Prevalent Information', American Review of Public Administration, 43(6), pp. 690-708

- Leflar, R. B. and M. H. Rogol (1976), 'Consumer Participation in the Regulation of Public Utilities: A Model Act', Harvard Journal on Legislation, 13(Feb 1976), pp. 235-297

- Levi-Faur, D. (2005), 'The Political Economy of Legal Globalization: Juridification, Adversarial Legalism, and Responsive Regulation. A comment', International Organization, 59(2), pp. 451462

- Levi-Faur, D. (2006), 'Varieties of Regulatory Capitalism: Getting the Most Out of the Comparative Method', Governance, 19(3), pp. 367-382

- Levi-Faur, D. (2011), 'Regulatory networks and regulatory agencification: towards a Single European Regulatory Space', Journal of European Public Policy, 18(6), pp. 810-829

- Levi-Faur, D. (2013), 'The Odyssey of the Regulatory State: From a "Thin" Monomorphic Concept to a "Thick" and Polymorphic Concept', Law \& Policy, 35(1-2), pp. 29-50

- Levine, P., J. Stern and F. Trillas (2005), 'Utility price regulation and time inconsistency: comparisons with monetary policy', Oxford Economic Papers, 57(3), pp. 447-478

- Levy, B. and P.T. Spiller (1994), 'Institutional Foundations of Regulatory Commitment: A Comparative Analysis of Telecommunications Regulation', Journal of Law, Economics \& Organization, 10(2), pp. 201-246

- Lewin, D., B. Williamson and M. Cave (2009), 'Regulating next-generation fixed access to telecommunications services', info, 11(4), pp. 3-18

- Lewis, T. and M. Poitevin (1997), 'Disclosure of Information in Regulatory Proceedings', Journal of Law, Economics \& Organization, 13(1), pp. 50-73 
- Li, H. and W. Suen (2004), 'Delegating decisions to experts', Journal of Political Economy, 112(S1), pp. S311-S335

- Li, Y. and B. Lyons (2012), 'Market structure, regulation and the speed of mobile network penetration', International Journal of Industrial Organization, 30(6), pp. 697-707

- Littlechild, S. (1983), 'Regulation of British Telecommunications' Profitability: Report to the Secretary of State', Department of Industry, February 1983

- Littlechild, S. (1988a), 'Spot pricing of electricity: Arguments and prospects', Energy Policy, 16(4), pp. 398-403

- Littlechild, S. (1988b), 'Economic regulation of privatised water authorities and some further reflections', Oxford Review of Economic Policy, 4(2), pp. 40-68

- Littlechild, S. (1994), 'Competition, Monopoly and Regulation in the Electricity Industry' Chapter 7 in M. A. Einhorn (ed.) 'From Regulation to Competition: New frontiers in electricity markets', Springer, pp. 125-149

- Littlechild, S. (2005), 'Smaller Suppliers in the UK Domestic Electricity Market: Experience, Concerns and Policy Recommendations, Working Paper

- Littlechild, S. (2006), 'Residential energy contracts and the 28 day rule', Utilities Policy, 14(1), pp. 44-62

- Littlechild, S. (2007), 'The Bird in the Hand: Stipulated Settlements and Electricity Regulation in Florida', Cambridge Working Papers in Economics CWPE 0713 and EPRG 0705, Available at: http://www.eprg.group.cam.ac.uk/wp-content/uploads/2008/11/eprg0705.pdf

- Littlechild, S. (2008), 'Municipal aggregation and retail competition in the Ohio energy sector', Journal of Regulatory Economics, 34(2), pp. 164-194

- Littlechild, S. (2010), 'The Creation of a Market for Retail Electricity Supply', RSCAS Working

Papers No 2010/57, Available at:

http://cadmus.eui.eu/dspace/bitstream/1814/14295/1/RSCAS_2010_57.pdf

- Littlechild, S. (2012), 'Ofgem and the Philosopher's Stone', Institute of Economic Affairs, 20 November 2012, Available at: http://www.iea.org.uk/blog/ofgem-and-the-philosophersstone.

- Livingstone, S., P. Lunt and L. Miller (2007), 'Citizens, consumers and the citizen-consumer: articulating the citizen interest in media and communications regulation', Discourse \& Communication, 1(1), pp. 63-89

- Lodge, M. (2008), 'Regulation, the Regulatory State and European Politics', West European Politics, 31(1-2), pp. 280-301

- Lodge, M. (2010), 'Regulating Infrastructures: The limits of the regulatory state' Der Moderne Staat, 3(1), pp. 71-87

- $\quad$ Lopez-de-Silanes, F., A. Shleifer and R. W. Vishny (1997), 'Privatization in the United States', RAND Journal of Economics, 28(3), pp. 447-471

- Loughlin, M. and C. Scott (1997), 'The Regulatory State' in P. Dunleavy, H. M. Drucker, A. Gamble, I. Holliday and G. Peele (eds.), 'Developments in British politics 5', Basingstoke: Palgrave Macmillan, pp. 205-219

- Lunn, P. and S. Lyons (2010), 'Behavioural Economics and 'Vulnerable Consumers': A Summary of Evidence', Economic and Social Research Institute for the Communications Consumer Panel, Available at: http://esri.ie/publications/search_for_a_publication/search_results/view/index.xml?id=314 9 
- $\quad$ Lunt, P. and S. Livingstone (2011), 'Media Regulation: Governance and the Interests of Citizens and Consumers', London: SAGE Publications

- Lüthi, S. and R. Wüstenhagen (2012), 'The price of policy risk-Empirical insights from choice experiments with European photovoltaic project developers', Energy Economics, 34(4), pp. 1001-1011

- Magat, W. A., A. J. Krupnick and W. Harrington (1986), 'Rules in the Making: A Statistical Analysis of Regulatory Agency Behavior', Washington D.C.: Resources for the Future

- Maggetti, M. (2007), 'De facto independence after delegation: A fuzzy-set analysis', Regulation \& Governance, 1(4), pp. 271-294

- Maggetti, M. (2009), 'The role of independent regulatory agencies in policy-making: a comparative analysis, Journal of European Public Policy, 16(3), pp. 450-470

- Maggetti, M. (2014), 'The Politics of Network Governance in Europe: The Case of Energy Regulation', West European Politics, 37(3), pp. 497-514

- Maggetti, M. (forthcoming), 'The rewards of cooperation: The effects of membership in European regulatory networks', European Journal of Political Research

- Maggetti, M. and F. Gilardi (2011), 'The policy-making structure of European regulatory networks and the domestic adoption of standards', Journal of European Public Policy, 18(6), pp. 830-847

- Maggetti, M., K. Ingold and F. Verone (2013), 'Having Your Cake and Eating It, Too: Can Regulatory Agencies Be Both Independent and Accountable?' Swiss Political Science Review, 19(1), pp. 1-25

- Maier, L. (1993), 'Institutional consumer representation in the European Community', Journal of Consumer Policy, 16(3-4), pp. 355-374

- Majone, G. (1994), 'The rise of the regulatory state in Europe', West European Politics, 17(3), pp. 77-101

- Majone, G. (1996), 'Regulating Europe', European Public Policy Series, London: Routledge

- Majone, G. (1997), 'From the Positive to the Regulatory State: Causes and Consequences of Changes in the Mode of Governance', Journal of Public Policy, 17(02), pp. 139-167

- Majone, G. (1999), 'The regulatory state and its legitimacy problems', West European Politics, 22(1), pp. 1-24

- Majone, G. (2006), 'The common sense of European integration', Journal of European Public Policy, 13(5), pp. 607-626

- Marks, G., L. Hooghe and K. Blank (1996), 'European Integration from the 1980s: State-Centric v. Multi-level Governance', Journal of Common Market Studies, 34(3), pp. 341-378

- Marneffe, W. and L. Vereeck (2011), 'The meaning of regulatory costs', European Journal of Law and Economics, 32(3), pp. 341-356

- Marshall, W.J., J.B. Yawitz, and E. Greenberg (1981), 'Optimal Regulation Under Uncertainty', The Journal of Finance, 36(4), pp. 909-921

- Martimort, D. (1996), 'The multiprincipal nature of government', European Economic Review, 40(3-5) pp. 673-685

- Martimort, D. (1999), 'The Life Cycle of Regulatory Agencies: Dynamic Capture and Transaction Costs', Review of Economic Studies, 66(4), pp. 929-947

- Martimort, D. and T. Verdier (2012), 'Optimal domestic regulation under asymmetric information and international trade: a simple general equilibrium approach', RAND Journal of Economics, 43(4), pp. 650-676 
- Martin, B. L. and K. Jayakar (2013), 'Moving beyond dichotomy: Comparing composite telecommunications regulatory governance indices', Telecommunications Policy, 37(9), pp. 691-701

- Maskin, E. and J. Tirole (2004), 'The Politician and the Judge: Accountability in Government', American Economic Review, 94(4), pp. 1034-1054

- Mathieu, E., K. Verhoest, D. Aubin and J. Matthys (2011), 'Regulatory agencies and multi-actor regulatory governance. A method to study regulatory fragmentation, specialization, coordination and centralization' EGPA Study Group on Governance of Public Sector Organizations - Conference of the European Group of Public Administration (EGPA), Working Paper

- Matteucci, G. and P. Reverberi (2005), 'Price Regulation and Public Service Obligations under International Arbitrage', Journal of Regulatory Economics, 28(1), pp. 91-113

- McChesney, F.S. (1987), 'Rent Extraction and Rent Creation in the Economic Theory of Regulation', Journal of Legal Studies, 16(1), pp. 101-118

- McCown, M. (2009), 'Interest Groups and the European Court of Justice' Chapter 5 in D. Coen and J. Richardson, 'Lobbying the European Union: Institutions, Actors, and Issues', Oxford: Oxford University Press

- McCubbins, M.D., R.G. Noll, and B.R. Weingast (1987), 'Administrative Procedures as Instruments of Political Control', Journal of Law, Economics, \& Organization, 3(2), pp. 243-277

- McCubbins, M.D, R.G. Noll, and B.R. Weingast (1999), 'The Political Origins of Administrative Procedure Act', Journal of Law, Economics, \& Organization, 15(1), pp. 180-217

- McFadden, D. (2006), 'Free Markets and Fettered Consumers', American Economic Review, 96(1), pp. 3-29

- McGowan, F. (2000), 'Consumer and Energy Liberalisation', Competition and Regulation in Network Industries, 1(3), pp. 353-374

- McGowan, F. and H. Wallace (1996), 'Towards a European regulatory state', Journal of European Public Policy, 3(4), pp. 560-576

- Meeus, L., I. Azevedo, C. Marcantonini, J-M. Glachant and M. Hafner (2012), 'EU 2050 LowCarbon Energy Future: Visions and Strategies', The Electricity Journal, 25(5), pp. 57-63

- Megginson, W. L. and J. M. Netter (2001), 'From State to Market: A Survey of Empirical Studies on Privatization', Journal of Economic Literature, 39(2), pp. 321-389

- Menezes, F. M. (2009), 'Consistent Regulation of Infrastructure Businesses: Some Economic Issues', Economic Papers, 28(1), pp. 2-10

- Menezes, F. M. and C. Roessler (2010), 'Good and Bad Consistency in Regulatory Decisions', Economic Record, 86(275), pp. 504-516

- Merrill, T. (1997), 'Capture Theory and the Courts: 1967-1983', Chicago-Kent Law Review, 72(4), pp. 1039-1117

- Meuwese, A., Y. Schuurmans and W. J. M. Voermans (2009), 'Towards a European Administrative Procedure Act', Review of European and Administrative Law, 2(2), pp. 3-35

- Milbourn, T. T., R. L. Shockley and A.V. Thakor (2001), 'Managerial career concerns and investments in information', Rand Journal of Economics, 32(2), pp. 334-351

- Miles, T. J. and C. R. Sunstein (2006), 'Do Judges Make Regulatory Policy? An Empirical Investigation of Chevron', University of Chicago Law Review, 73(3), pp. 823-881

- Milgrom, P. and J. Roberts (1986), 'Relying on the information of interested parties', RAND Journal of Economics, 17(1), pp. 18-32 
- Miravete, E. J. (2003), 'Choosing the Wrong Calling Plan? Ignorance and Learning', American Economic Review, 93(1), pp. 297-310

- Mitnick, B. M. (1973), 'Fiduciary rationality and public policy: the theory of agency and some consequences', University of Pittsburgh, Working Paper, Available at: http://papers.ssrn.com/sol3/papers.cfm?abstract_id=1020859

- Mitnick, B. M. (1975), 'The theory of agency', Public Choice, 24(1), pp. 27-42

- Moita, R. and C. Paiva (2013), 'Political Price Cycles in Regulated Industries: Theory and Evidence', American Economic Journal: Economic Policy, 5(1), pp. 94-121

- Monast, J. J. and S. K. Adair (2013), 'A Triple Bottom Line for Electric Utility Regulation: Aligning State-Level Energy, Environmental and Consumer Protection Goals', Columbia Journal of Environmental Law, 38(1), pp. 1-65

- Monti, G. (2008), 'Managing the intersection of utilities regulation and EC Competition Law', Competition Law Review, 4(2), pp. 123-145

- Montolio, D. and F. Trillas (2013), 'Regulatory federalism and industrial policy in broadband telecommunications', Information Economics and Policy, 25(1), pp. 18-31

- Montoya, M. A. and F. Trillas (2009), 'The measurement of regulator independence in practice: Latin America and the Caribbean', International Journal of Public Policy, 4(1), pp. 113-134

- Mookherjee, D. (2006), 'Decentralization, Hierarchies, and Incentives: A Mechanism Design Perspective', Journal of Economic Literature, 44(2), pp. 367-390

- Moran, M. (2002), 'Review Article: Understanding the Regulatory State', British Journal of Political Science, 32(2), pp. 391-413

- Moran, M. (2004), 'The British Regulatory State: High Modernism and Hyper Innovation', Oxford: Oxford University Press

- Moravcsik, A. (2002), 'Reassessing legitimacy in the European Union', Journal of Common Market Studies, 40(4), pp. 603-624

- Moravcsik, A. (2004), 'Is there a 'Democratic Deficit' in World Politics? A Framework for Analysis." Government and Opposition', 39(2), pp. 336-363

- Mulholland, J. P. (2007), 'Behavioral Economics and the Federal Trade Commission', Working Paper, Available at: http://papers.ssrn.com/sol3/papers.cfm?abstract_id=1091745

- Mumford, J. and D. Gray (2010), 'Consumer engagement in alternative energy-Can the regulators and suppliers be trusted?', Energy Policy, 38(6), pp. 2664-2671

- Muris, T. J. (2002). 'The Interface of Competition and Consumer Protection', Presentation to the Fordham Corporate Law Institute's $29^{\text {th }}$ Annual Conference on International Law and Policy, New York City, 31 October 2002

- National Audit Office (NAO) (2004), 'Energywatch and Postwatch: Helping and Protecting Consumers', HC 1076 Session 2003-2004, London: The Stationary Office

- National Audit Office (NAO) (2008), 'Protecting consumers? Removing retail price controls', HC342 Session 2007-2008, London: The Stationery Office

- Neuhoff, K. and D. Newbery (2005), 'Evolution of electricity markets: Does sequencing matter?', Utilities Policy, 13(2), pp. 163-173

- Neven, D. J. and L.-H. Röller (2000), 'The allocation of jurisdiction in international antitrust', European Economic Review, 44(4), pp. 845-855

- Newbery, D.M. (1993), 'The Impact of EC Environmental Policy on British Coal', Oxford Review of Economic Policy, 9(4), pp. 66-95

- Newbery, D. M. (1997), 'Privatisation and liberalisation of network utilities', European Economic Review, 41(3-5), pp. 357-383 
- Newbery, D. M. (1999), 'Privatization, restructuring, and regulation of network utilities', Cambridge, MA: MIT press

- Newbery, D. M. (2004), 'Regulation and competition policy: longer-term boundaries', Utilities Policy, 12(2), pp. 93-95

- Newbery, D. (2005), 'Integrating electricity transmission systems', Utilities Policy, 13(2), pp. 69-71

- Newbery, D.M. (2008), 'Climate change policy and its effect on market power in the gas market', Journal of the European Economic Association, 6(4), pp. 727-751

- Newbery, D. M. and M. G. Pollitt (1997), 'The Restructuring and Privatisation of Britain's CEGB-Was It Worth It?', The Journal of Industrial Economics, 45(3), pp. 269-303

- Nicolaides, P. (2004), 'The Political Economy of Multi-tiered Regulation in Europe', Journal of Common Market Studies, 42(3), pp. 599-618

- Nillesen, P.H.L. and M.G. Pollitt (2004), 'The Consequences for Consumer Welfare of the 20012003 Electricity Distribution Price Review in The Netherlands', CMI Working Paper 50, Available at: https://www.repository.cam.ac.uk/handle/1810/131580

- Norton, S.W. (1985), 'Regulation and Systematic Risk: The Case of Electric Utilities', Journal of Law and Economics, 28(3), pp. 671-686

- Oates, W. E. (1999), 'An Essay on Fiscal Federalism', Journal of Economic Literature, 37(3), pp. 1120-1149

- OECD (2005), 'Designing Independent and Accountable Regulatory Authorities for High Quality Regulation', Working Party on Regulatory Management and Reform, Available at: www.oecd.org/dataoecd/15/28/35028836.pdf

- Ofcom (2010), 'Using experiments in consumer research', Research Document, 1 March 2010, Available at: http://stakeholders.ofcom.org.uk/market-data-research/other/telecomsresearch/experiments/

- Office of Fair Trading and Competition Commission (2009), 'Road Testing of Consumer Remedies: Final Report', OFT1099

- Ofgem (2006), 'Vulnerable Customers \& Codes Workgroup - Final Report to the Supply Licence Review Steering Group', Available at: http://webarchive.nationalarchives.gov.uk/20130402174434/http://www.ofgem.gov.uk/Pag es/Morelnformation.aspx?docid=4\&refer=Markets/RetMkts/Compl/SLR/WorkGrps/VulnCus $\mathrm{t}$

- Ofgem (2011), 'What can behavioural economics say about GB energy consumers?', Available at: https://www.ofgem.gov.uk/publications-and-updates/what-can-behavioural-economicssay-about-gb-energy-consumers-0

- Ogden, S. G. (1997), 'Accounting for organizational performance: the construction of the customer in the privatized water industry', Accounting, Organizations and Society, 22(6), pp. 529-556

- Ogden, S. and F. Anderson (1995), 'Representing Customers' Interests: The case of the Privatized Water Industry in England and Wales', Public Administration, 73(4), pp. 535-559

- Ogus, A., M.J. Faure, and N.J. Philipsen (2006), 'Best Practice for Consumer Policy: Report on the Effectiveness of Enforcement Regimes', Committee on Consumer Policy, Directorate for Science, Technology and Industry, OECD, DSTI/CP(2006)21/FINAL, Available at: www.oecd.org/dataoecd/56/7/37863861.doc

- Oğuz, F. (2010), 'Competition by regulation in energy markets: the case of Turkey', European Journal of Law and Economics, 30(1), pp. 41-58 
- Oliver, D., T. Prosser and R. Rawlings (eds.) (2010), 'The Regulatory State: Constitutional Implications', Oxford: Oxford University Press

- Olsen, J. (2003), 'Towards a European administrative space?', Journal of European Public Policy, 10(4), pp. 506-531

- Osborne, D. and T. Gaebler (1993), 'Reinventing Government: How the Entrepreneurial Spirit is Transforming the Public Sector', New York: Plume

- Oxera (2010), 'Behavioural economics, competition and remedy design', Agenda, November 2010, Available at: http://www.oxera.com/Latest-Thinking/Agenda/2010/Behaviouraleconomics,-competition-and-remedy-desi.aspx

- Page, B. and K. Bakker (2005), 'Water governance and water users in a privatised water industry: participation in policy-making and in water services provision: a case study of England and Wales', International Journal of Water, 3(1), pp. 38-60

- Panzar, J.C. and R.D. Willig, 'Economies of Scope', American Economic Review, 71(2), pp. 268272

- Park, M. (2011), 'The economic impact of wireless number portability', Journal of Industrial Economics, 59(4), pp. 714-745

- Parker, D. (1998), 'Developments: Reducing Regulatory Risk: The Case for a New Regulatory Contract with the Privatized Utilities', Public Money and Management, 18(4), pp. 51-57

- Parker, D. (2013), 'The privatized railways: problems foreseen', Public Money \& Management, 33(5), pp. 313-319

- Parker, D. and C. Kirkpatrick (2012), 'The Economic Impact of Regulatory Policy: A Literature Review of Quantitative Evidence, OECD Expert Paper No. 3, August 2012, Available at: http://www.oecd.org/gov/regulatory-policy/Publications-MRP.htm

- Pautz, M. C. (2009), 'Perceptions of the regulated community in environmental policy: the view from below', Review of Policy Research, 26(5), pp. 533-550

- Peltzman, S. (1976), 'Toward a More General Theory of Regulation', Journal of Law and Economics, 19(2), pp. 211-240

- Pflieger, G. (2014), 'What "Regulatory State"? Explaining the Stability of Public Spending and Redistribution Functions after Regulatory Reforms of Electricity and Rail Services in the United Kingdom and Germany', Law \& Policy, 36(2), pp. 195-221

- Pflieger, G. and P. Csikos (2012), 'Regulation of Liberalised Network Industries: Infostructure as a Missing Link', Swiss Political Science Review, 18(4), pp. 428-451

- Piattoni, S. (2009), 'Multi-level Governance: a Historical and Conceptual Analysis', Journal of European Integration, 31(2), pp. 163-180

- Pinotti, P. (2012), 'Trust, Regulation and Market Failures', Review of Economics and Statistics, 94(3), pp. 650-658

- Pint, E.M. (1992), 'Price-cap versus rate-of-return regulation in a stochastic-cost model', RAND Journal of Economics, 23(4), pp. 564-578

- Pollack, M. A. (1997), 'Representing diffuse interests in EC policy-making', Journal of European Public Policy, 4(4), pp. 572-590

- Pollack, M. (2002), 'Learning from the Americanists (Again): Theory and Method in the Study of Delegation', West European Politics, 25(1), pp. 200-219

- Pollitt, C. (2000), 'Is the emperor in his underwear? An analysis of the impacts of public management reform', Public Management, 2(2), pp. 181-200

- Pollitt, C. (2001), 'CLARIFYING CONVERGENCE. Striking similarities and durable differences in public management reform', Public Management Review, 3(4), pp. 471-492Pollitt, M. (2010), 
'Does electricity (and heat) network regulation have anything to learn from fixed line telecoms regulation?', Energy Policy, 38(3), pp. 1360-1371

- Pollitt, C. and G. Bouckaert (2011), 'Public management reform: A comparative analysis-new public management, governance, and the Neo-Weberian state', $3^{\text {rd }}$ edition, Oxford: Oxford University Press

- Pollitt, M. and J. Stern (2011), 'Human resource constraints for electricity regulation in developing countries: developments since 2001', Utilities Policy, 19(2), pp. 53-60

- Poncibò, C. (2012), 'Networks to Enforce European Law: The Case of the Consumer Protection Cooperation Network', Journal of Consumer Policy, 35(2), pp. 175-195

- Popelier, P. (2012), 'Preliminary Comments on the Role of Courts as Regulatory Watchdogs', Legisprudence, 6(3), pp. 257-270

- Posner, E.A. (2001), 'Controlling Agencies with Cost-Benefit Analysis: A Positive Political Theory Perspective', University of Chicago Law Review, 68(4), pp. 1137-1199

- Posner, R. A. (1993), 'What Do Judges and Justices Maximize? (The Same Thing Everybody Else Does)', Supreme Court Economic Review, 3, pp. 1-41Prahalad, C.K. and G. Hamel (1990), 'The Core Competence of the Corporation', Harvard Business Review, 68(3), pp. 79-91

- Prendergast, C. (1993), 'A Theory of "Yes Men"', American Economic Review, 83(4), pp. 757770

- Prendergast, C. (2002), 'Consumers and agency problems', Economic Journal, 112(478), pp. C34-C51

- Prosser, T. (1995), 'Social limits to privatization', Brooklyn Journal of International Law, 21, pp. 213-

- Prosser, T. (2005a), 'Competition Law and Public Services From Single Market to Citizenship Rights?', European Public Law, 11(4), pp. 543-563

- Prosser, T. (2005b), 'The Limits of Competition Law: Markets and Public Services', Oxford: Oxford University Press

- Prosser, T. (2006), 'Regulation and social solidarity', Journal of Law and Society, 33(3), pp. 364387

- Prosser, T. (2010), 'The Regulatory Enterprise: Government, Regulation, and Legitimacy', Oxford: Oxford University Press

- Radaelli, C. M. (1999), 'The public policy of the European Union: whither politics of expertise?', Journal of European Public Policy, 6(5), pp. 757-774

- Radaelli, C. M. (2004), 'The diffusion of regulatory impact analysis - Best practice or lessondrawing?', European Journal of Political Research, 43(5), pp. 723-747

- Radaelli, C. M. (2005), 'Diffusion without convergence: how political context shapes the adoption of regulatory impact assessment', Journal of European Public Policy, 12(5), pp. 924943

- Radaelli, C. M. (2009a), 'Desperately Seeking Regulatory Impact Assessments: Diary of a Reflective Researcher', Evaluation, 15(1), pp. 31-48

- Radaelli, C. M. (2009b), 'Measuring policy learning: regulatory impact assessment in Europe', Journal of European Public Policy, 16(8), pp. 1145-1164

- Radaelli, C. M. (2010a), 'Regulating Rule-Making via Impact Assessment', Governance, 23(1), pp. 89-108

- Radaelli, C. M. (2010b), 'Rationality, Power, Management and Symbols: Four Images of Regulatory Impact Assessment', Scandinavian Political Studies, 33(2), pp. 164-188

- Radaelli, C. M. and F. De Francesco (2007), 'Regulatory Impact Assessment, Political Control and the Regulatory State', Working Paper 
- Radaelli, C. M., F. De Francesco and V.E. Troeger (2008), 'Implementation of Regulatory Impact Assessment in Europe', Working Paper

- Radaelli, C. and O. Fritsch (2012), 'Evaluating Regulatory Management Tools and Programmes', OECD Measuring Regulatory Performance Expert Paper No. 2, July 2012, Available at: http://www.oecd.org/gov/regulatory-policy/Publications-MRP.htm

- Radaelli, C. M. and A. C. M. Meuwese (2012), 'How the regulatory state differs. The constitutional dimensions of rulemaking in the European Union and the United States', Rivista italiana di scienza politica, 2012(2), pp. 177-196

- Ramello, G.B. (2012), 'Aggregate litigation and regulatory innovation: Another view of judicial efficiency', International Review of Law and Economics, 32(1), pp. 63-71

- Ramsay, I. (2006), 'Consumer Law, Regulatory Capitalism and the New Learning in Regulation', Sydney Law Rev, 28(1), pp. 9-35

- Rayner, S. (2003), 'Democracy in the age of assessment: Reflections on the roles of expertise and democracy in public-sector decision making', Science and Public Policy, 30(3), pp. 163-170

- Reisch, L. and H-W. Micklitz (2006), 'Consumers and deregulation of the electricity market in Germany', Journal of Consumer Policy, 29(4), pp. 399-415

- Renda, A. (2006), 'Impact Assessment in the EU: The State of the Art and the Art of the State', Brussels: Centre for European Policy Studies

- Rhodes, R. A. W. (1994), 'The hollowing out of the state: the changing nature of the public service in Britain', The Political Quarterly, 65(2), pp. 138-151

- Rhodes, R. A. W. (1996), 'The New Governance: Governing without Government', Political Studies, 44(4), pp. 652-667

- Rhodes, R. A. W. (2002), 'Putting People Back into Networks', Australian Journal of Political Science, 37(3), pp. 399-416

- Risk, R. (1984), 'Lawyers, Courts, and the Rise of the Regulatory State', Dalhousie Law Journal, 9, pp. 31-

- Rizzo, M. J. and D.G. Whitman (2009a), 'The knowledge problem of the new paternalism', Brigham Young University Law Review, 2009(4), pp. 103-161

- Rizzo, M. J. and D. G. Whitman (2009b), 'Little Brother is Watching You: New Paternalism on the Slippery Slopes', Arizona Law Review, 51(3), pp. 685-739

- Robinson, G. H. (1928), 'The Public Utility Concept in American Law', Harvard Law Review, 41(3), pp. 277-308

- Rodrik, D. (2008), 'Second-Best Institutions', American Economic Review, 98(2), pp. 100-104

- Roldán, F. (2013), 'The organization of expertise in the presence of communication', Review of Economic Design, 17(1), pp. 63-81

- Rommel, J. and K. Verhoest (2008), 'Proliferation and specialisation of regulatory bodies in Belgium', Working Paper, Katholieke Universiteit Leuven

- Rose, N. L. (2014), 'Learning from the Past: Insights for the Regulation of Economic Activity' In N.L. Rose (ed.) 'Economic Regulation and Its Reform: What Have We Learned?', Chicago: University of Chicago Press

- Rose-Ackerman, S. (1991), 'Regulation and the Law of Torts', American Economic Review, 81(2), pp. 54-58

- Rotemberg, J. J. and G. Saloner (1994), 'Benefits of narrow business strategies', American Economic Review, 84(5), pp. 1330-1349

- Sadowska, M. and B. Willems (2013), 'Power Markets Shaped by Antitrust', European Competition Journal, 9(1), pp. 131-173 
- Salant, D.J. (1995), 'Behind the revolving door: a new view of public utility regulation', RAND Journal of Economics, 26(3), pp. 362-377

- Salant, D. (2000), 'Auctions and Regulation: Reengineering of Regulatory Mechanisms', Journal of Regulatory Economics, 17(3), pp. 195-204

- Sanz, M. P., M. Schouten and M. Hantke-Domas (2011), 'Consumer-inclusive economic regulation: water pricing under different regulatory regimes', Water Policy, 13(4), pp. 459-470

- Sappington, D.E. (1986), 'Commitment to regulatory bureaucracy', Information Economics and Policy, 2(4), pp. 243-258

- Sappington, D. E. (2005), 'Regulating Service Quality: A Survey', Journal of Regulatory Economics, 27(2), pp. 123-154

- Sappington, D.E. and D.L. Weisman (2012), 'Regulating regulators in transitionally competitive markets', Journal of Regulatory Economics, 41(1), pp. 19-40

- Schaefer, H-B. (2000), The Bundling of Similar Interests in Litigation. The Incentives for Class Action and Legal Actions taken by Associations', European Journal of Law and Economics, 9(3), pp. $183-213$

- Scharfstein, D. S. and J. C. Stein (1990), 'Herd Behavior and Investment', American Economic Review, 80(3), pp. 465-479

- Schinkel, M. P., L. Tóth and J. Tuinstra (2013), 'Prioritizing in Government Agencies: Performance Effects of Budget Cuts and Institutional Mergers', Working Paper

- Schmalensee, R. and R. Stavins (2013), 'The $\mathrm{SO}_{2}$ Allowance Trading System: The Ironic History of a Grand Policy Experiment, Journal of Economic Perspectives, 27(1), pp. 103-121

- Schrefler, L. (2013), 'Economic Knowledge in Regulation: The Use of Expertise by Independent Agencies', Colchester: ECPR Press

- Schwarze, J. (1992), 'European Administrative Law', London: Sweet and Maxwell

- Scott, C. (1998), 'The juridification of regulatory relations in the UK utilities sectors', Chapter 1 in J. Black, P. Muchlinski and P. Walker, 'Commercial Regulation and Judicial Review', Oxford: Hart

- Scott, C. (2000), 'Accountability in the Regulatory State', Journal of Law and Society, 27(1), pp. 38-60

- Seidman, H. and R. S. Gilmour (1986), 'Politics, Position, and Power: From the Positive to the Regulatory State', New York: Oxford University Press

- Shapiro, M. M. (1988), 'Who Guards the Guardians?: Judicial Control of Administration', Athens, USA: University of Georgia Press

- Shapiro, S. A. and R. E. Levy (1987), 'Heightened Scrutiny of the Fourth Branch: Separation of Powers and the Requirement of Adequate Reasons for Agency Decisions', Duke Law Journal, 1987(3), pp. 387-455

- Sharratt, D., B. H. Brigham and M. Brigham (2007), 'The Utility of Social Obligations in the UK Energy Industry', Journal of Management Studies, 44(8), pp. 1503-1522

- Shavell, S. (1984), 'Liability for harm versus regulation of safety', Journal of Legal Studies, 13(2), pp. 357-374

- Shavell, S. (1997), 'The Fundamental Divergence between the Private and the Social Motive to Use the Legal System', Journal of Legal Studies, 26(S2), pp. 575-612

- Shi, M., J. Chiang and B.D. Rhee (2006), 'Price competition with reduced consumer switching costs: The case of "wireless number portability" in the cellular phone industry', Management Science, 52(1), pp. 27-38 
- Shleifer, A. (1985), 'A theory of yardstick competition', RAND Journal of Economics, 16(3), pp. 319-327

- Shleifer, A. (2005), 'Understanding Regulation', European Financial Management, 11(4), pp. 439-451.

- Shleifer, A. (2011), 'Efficient Regulation', Chapter 2 in D. P. Kessler (ed.) 'Regulation versus Litigation: Perspectives from Economics and Law', Chicago: University of Chicago Press, pp. 27-43

- Sidak, j. G. and D. F. Spulber (1998), 'Deregulation and Managed Competition in Network Industries', Yale Journal on Regulation, 15(1), pp. 117-147

- Simmonds, G. (2002). 'Consumer Representation in Europe: Policy and Practice for Utilities and Network Industries, Part II: Consumer Representation within the EU Decision-Making Process', Centre for the Study of Regulated Industries, Research Report 11, Available at: www.bath.ac.uk/management/cri/pubpdf/.../11_Part_2_Simmonds.pdf

- Sitzia, S., J. Zheng and D.J. Zizzo (2012), 'Complexity and Smart Nudges with Inattentive Consumers', Centre for Competition Policy, Working Paper 12-13, Available at: http://competitionpolicy.ac.uk/publications/working-papers-2012

- Slaughter, A.-M. and D. Zaring (2006), 'Networking Goes International: An Update', Annual Review of Law and Social Science, 2, pp. 211-229

- Smyth, R. and M. Söderberg (2010), 'Public interest versus regulatory capture in the Swedish electricity market', Journal of Regulatory Economics, 38(3), pp. 292-312

- Sobel, J. (2010), 'Giving and receiving advice', Working Paper

- Spanjer, A. (2008), 'European Gas Regulation - A Theoretical Critique', Chapter 8 in F. L. Magnusson and O. W. Bengtsson, 'Energy in Europe: Economics, Policy and Strategy', New York: Nova Publishers, pp. 257-314

- Spiegel, Y. and D. F. Spulber (1994), 'The capital structure of a regulated firm', RAND Journal of Economics, 25(3), pp. 424-440

- Spiller, P. T. (1983), 'The Differential Impact of Airline Regulation on Individual Firms and Markets: An Empirical Analysis', Journal of Law and Economics, 26(3), pp. 655-689

- Spiller, P.T. (1990), 'Politicians, Interest Groups, and Regulators: A Multiple-Principals Agency Theory of Regulation, or" Let Them Be Bribed"', Journal of Law and Economics, 33(1), pp. 65101

- Spiller, P. T. (1996), 'Institutions and commitment', Industrial and Corporate Change, 5(2), pp. 421-452

- Spiller, P. T. and J. Ferejohn (1992), 'Economics and Politics of Administrative Law and Procedures: An Introduction', Journal of Law Economics \& Organization, 8(1), pp. 1-17

- Spiller, P. T. and S. Urbiztondo (1994), 'Political appointees vs. career civil servants: A multiple principals theory of political bureaucracies', European Journal of Political Economy, 10(3), pp. 465-497

- Spiller, P. T. and E. H. Tiller (1997), 'Decision Costs and the Strategic Design of Administrative Process and Judicial Review', Journal of Legal Studies, 26(2), pp. 347-370

- Spiller, P. T. and I. Vogelsang (1997), 'The institutional foundations of regulatory commitment in the UK: the case of telecommunications', Journal of Institutional and Theoretical Economics, 153(4), pp. 607-629

- Spiller, P. T. and M. Tommasi (2005), 'The Institutions of Regulation: An Application to Public Utilities' Chapter 20 in C. Menard and M. M. Shirley (eds.), 'Handbook of New Institutional Economics', Springer, pp. 515-543 
- Ştefan, O. A. (2008), 'European Competition Soft Law in European Courts: A Matter of Hard Principles?', European Law Journal, 14(6), pp. 753-772

- Stein, D. G. (2011), 'Perilous Proxies: Issues of Scale for Consumer Representation in Agency Proceedings', N.Y.U. Annual Survey of American Law, 67, pp. 513-588

- Stern, J. (1997), 'What makes an independent regulator independent?', Business Strategy Review, 8(2), pp. 67-74

- Stern, J. (2000), 'Electricity and telecommunications regulatory institutions in small and developing countries', Utilities Policy, 9(3), pp. 131-157

- Stern, J. (2004), 'Regulatory forbearance: why did Oftel find it so hard?', Telecommunications Policy, 28(3-4), pp. 273-294

- Stern, J. (2010), 'Introducing competition into England and Wales water industry-Lessons from UK and EU energy market liberalisation', Utilities Policy, 18(3), pp. 120-128

- Stern, J. and S. Holder (1999), 'Regulatory governance: criteria for assessing the performance of regulatory systems: an application to infrastructure industries in the developing countries of Asia', Utilities Policy, 8(1), pp. 33-50

- Stern, J. and F. Trillas (2003), 'Independence and discretion in telecommunications regulation: lessons from independent central banks', Utilities Policy, 11(4), pp. 191-201

- Steunenberg, B. (1996), 'Agent discretion, regulatory policymaking, and different institutional arrangements', Public Choice, 86(3-4), pp. 309-339

- Stewart, R. B. (2005), 'U.S. Administrative Law: A Model for Global Administrative Law?', Law and Contemporary Problems, 68(3-4), pp. 63-108

- Stigler, G.J. (1971), 'The Theory of Economic Regulation', Bell Journal of Economics and Management Science, 2(1), pp. 3-21

- Stirton, L. and M. Lodge (2001), 'Transparency Mechanisms: Building Publicness into Public Services', Journal of Law and Society, 28(4), pp. 471-489

- Strausz, R. (2011), 'Regulatory Risk Under Optimal Monopoly Regulation', Economic Journal, 121(553), pp. 740-762

- Stuyck, J. (2005), 'EC Competition Law After Modernisation: More than Ever in the Interest of Consumers', Journal of Consumer Policy, 28(1), pp. 1-30

- Sunstein, C. R. (1987), 'Constitutionalism after the New Deal', Harvard Law Review, 101(2), pp. 421-510

- Sunstein, C. R. (1989a), 'Interpreting Statutes in the Regulatory State', Harvard Law Review, 103(2), pp. 405-508

- Sunstein, C. R. (1989b), 'On the Costs and Benefits of Aggressive Judicial Review of Agency Action', Duke Law Journal, 1989(3), pp. 522-537

- Sunstein, C. R. (1990), 'Paradoxes of the Regulatory State', University of Chicago Law Review, 57(2), pp. 407-441

- Sunstein, C.R. (2002), 'The Cost-Benefit State: The Future of Regulatory Protection', Chicago: American Bar Association

- Sunstein, C. R. (2011), 'Empirically Informed Regulation', University of Chicago Law Review, 78(4), pp. 1349-1429

- Tangerås, T. P. (2002), 'Collusion-proof yardstick competition', Journal of Public Economics, 83(2), pp. 231-254

- Tangerås, T. P. (2012), 'Optimal transmission regulation of an integrated energy market', Energy Economics, 34(5), pp. 1644-1655 
- Tanzi, V. (2011), 'Government Versus Markets: The Changing Economic Role of the State', New York: Cambridge University Press, Chapter 14, pp. 305-334

- Tapia, J. and D. Mantzari (2013), 'The Regulation/Competition Interaction', Chapter 14 in D. Geradin and I. Lianos (eds.), 'Handbook on European Competition Law, Volume 1: Substantive Aspects', Cheltenham: Edward-Elgar, pp. 588-628

- Tasic, S. (2011), 'Are Regulators Rational?', Journal des Economistes et des Etudes Humaines, 17(1), pp. 1-21

- Temple-Lang, J. (2009), 'European Competition Policy and Regulation: Differences, Overlaps and Constraints', Chapter 2 in F. Leveque and H. Shelanski (eds.), 'Antitrust and Regulation in the EU and US: Legal and Economic Perspectives', New Horizons in Competition Law and Economics series, Cheltenham: Edward Elgar, pp. 20-75

- Thatcher, M. (2002a), 'Regulation after delegation: independent regulatory agencies in Europe', Journal of European Public Policy, 9(6), pp. 954-972

- Thatcher, M. (2002b), 'Delegation to Independent Regulatory Agencies: Pressures, Functions and Contextual Mediation', West European Politics, 25(1), pp. 125-147

- Thatcher, M. (2005), 'The Third Force? Independent Regulatory Agencies and Elected Politicians in Europe', Governance, 18(3), pp. 347-373

- Thatcher, M. (2011), 'The creation of European regulatory agencies and its limits: a comparative analysis of European delegation', Journal of European Public Policy, 18(6), pp. 790-809

- Thatcher, M. and A. S. Sweet (2002), 'Theory and Practice of Delegation to Non-Majoritarian Institutions', West European Politics, 25(1), pp. 1-22

- Tiller, E. H. and P. T. Spiller (1999), 'Strategic instruments: Legal structure and political games in administrative law', Journal of Law, Economics \& Organization, 15(2), pp. 349-377

- Tirole, J. (1994), 'The internal organization of government', Oxford Economic Papers, 46(1), pp. $1-29$

- Tirole, J. (1999), 'The Institutional Infrastructure of Competition Policy', Working Paper, Institut D'Economie Industrielle, Toulouse

- Torriti, J. (2008), 'A Review of the European Commission's Impact Assessment for the third legislative package on energy markets liberalisation', Working Paper, Available at: http://ieeexplore.ieee.org/xpl/mostRecentlssue.jsp?punumber=4568047

- Torriti, J. (2010), 'Impact Assessment and the Liberalization of the EU Energy Markets: Evidence-Based Policy-Making or Policy-Based Evidence-Making?, Journal of Common Market Studies, 48(4), pp. 1065-1081

- Torriti, J. (2011), 'The unsustainable rationality of Impact Assessment', European Journal of Law and Economics, 31(3), pp. 307-320

- Trillas, F. (2008), 'Regulatory federalism in network industries', IEB Working Papers No. 2008/8, Available at: http://ieb.ub.edu/aplicacio/fitxers/2009/3/Doc2008-8.pdf

- Trillas, F. (2010a), 'Network industries and regulatory jurisdiction', IESE Research Papers No. D/859, Available at: http://www.iese.edu/research/pdfs/DI-0859-E.pdf

- Trillas, F. (2010b), 'Electricity and telecoms reforms in the EU: Insights from the economics of federalism', Utilities Policy, 18(2), pp. 66-76

- Trillas, F. (2011), 'Regulatory federalism in telecommunications', Cuadernos económicos de ICE No. 81, pp. 9-37

- Trillas, F. and M. A. Montoya (2008), 'The degree of commitment to regulator independence: measurement and impact', Hacienda Pública Española, 185(2), pp. 89-114 
- Trondal, J. and B. G. Peters (2013), 'The Rise of European Administrative Space: Lessons Learned', Journal of European Public Policy, 20(2), pp. 295-307

- Turk, A. H. (2009), 'Judicial Review in EU Law', Cheltenham: Edward Elgar

- Turner, S. (2001), 'What is the Problem with Experts?', Social Studies of Science, 31(1), pp. 123-149

- Ugur, M. (2009), 'Regulatory Quality and Performance in EU Network Industries: Evidence on Telecommunications, Gas and Electricity', Journal of Public Policy, 29(03), pp. 347-370

- Urbiztondo, S., J-P. Bonardi, and B.V. Quelin (2013), 'International expansion, diversification and regulated firms' nonmarket strategy', Managerial and Decision Economics, 34(6), pp. 379-396

- Valletti, T. M., S. Hoernig and P. P. Barros (2002), 'Universal Service and Entry: The Role of Uniform Pricing and Coverage Constraints', Journal of Regulatory Economics, 21(2), pp. 169190

- Valsecchi, I. (2013), 'The expert problem: a survey', Economics of Governance, 14(4), pp. 303331

- Van Boetzelaer, K. and S. Princen (2012), 'The Quest for Co-ordination in European Regulatory Networks', Journal of Common Market Studies, 50(5), pp. 819-836

- Van Den Burgh, R.J. and A.M. Pacces (eds.) (2012), 'Regulation and Economics', 'Encyclopedia of Law and Economics', Volume 9, $2^{\text {nd }}$ edition, Cheltenham: Edward Elgar

- Vass, P. (2003), 'Consumer Representation: Integration or Independence?', Chapter 2 in P. Vass (ed.) 'Regulatory Practice and Design - A collection of reviews relating to utilities and network industries', Collection Series 2, Bath: Centre for the study of Regulated Industries

- Vickers, J. (2004), 'Economics for consumer policy', in P.J. Marshall (ed.), 'Proceedings of the British Academy: 2003 Lectures', Volume 125, Oxford: Oxford University Press

- Vickers, J. and G. K. Yarrow (1988), 'Privatization: An Economic Analysis', Cambridge, MA: MIT PressVidal, J.B.I., M. Draca, and C. Fons-Rosen (2012), 'Revolving Door Lobbyists', American Economic Review, 102(7), pp. 3731-3748

- Viscusi, W. K. (ed.) (2002), 'Regulation through Litigation', Washington D.C.: Brookings Institution Press

- Viscusi, W.K., J.E. Harrington, Jr, and J.M. Vernon (2005), 'Economics of Regulation and Antitrust', 4th edition, Cambridge, M.A.: MIT Press, Chapter 10, pp. 355-399

- Visser, B. and O. H. Swank (2007), 'On committees of experts', Quarterly Journal of Economic, 122(1), pp. 337-372

- Vogelsang, I. (1989), 'Price Cap Regulation of Telecommunications Services: A Long-Run Approach', Chapter 3 in M. A. Crew (ed.), 'Deregulation and Diversification of Utilities', Topics in Regulatory Economics and Policy, Volume 3, Springer, pp. 21-42

- Vogelsang, I. (2003), 'Price Regulation of Access to Telecommunications Networks', Journal of Economic Literature, 41(3), pp. 830-862

- Vogelsang, I. (2010), 'The Tension Between Incentive Regulation and Investments in Network Industries', CESifo DICE Report, 8(3), pp. 13-18, Available at: http://www.cesifogroup.de/portal/page/portal/DocB ... report310-forum3.pdf

- Vogelsang, I., N. Ramphal, S.J. Carroll and N.M. Pace (2007), 'An economic analysis of consumer class actions in regulated industries', Journal of Regulatory Economics, 32(1), pp. 87-104Von Der Fehr, N-H. M. and P. V. Hansen (2010), 'Electricity retailing in Norway', Energy Journal, 31(1), pp. 25-45 
- Waddams Price, C. (2004), 'Spoilt for Choice? The Costs and Benefits of Opening UK Residential Energy Markets', Centre for Competition and Regulation, Working Paper CCR 041

- Waddams Price, C. and R. Hancock (1998), 'Distributional Effects of Liberalising UK Residential Utility Markets', Fiscal Studies, 19(3), pp. 295-319

- Waddams Price, C. and M. Bennett (1999), 'New gas in old pipes: opening the UK residential gas market to competition', Utilities Policy, 8(1), pp. 1-15

- Waddams Price, C., C. Webster and M. Zhu (2013), 'Searching and Switching: Empirical estimates of consumer behaviour in regulated markets', Centre for Competition Policy, Working Paper 13-11, Available at: http://competitionpolicy.ac.uk/publications/workingpapers-2013

- Waterson, M. (2003), 'The role of consumers in competition and competition policy', International Journal of Industrial Organization, 21(2), pp. 129-150

- Waverman, L. and P. Koutroumpis (2011), 'Benchmarking telecoms regulation - The Telecommunications Regulatory Governance Index (TRGI)', Telecommunications Policy, 35(5), pp. $450-468$

- Weisman, D.L. (2006), 'When can regulation defer to competition for constraining market power?: Complements and critical elasticities', Journal of Competition Law and Economics, 2(1), pp. 101-112

- Wiener, J. (2013), 'The Diffusion of Regulatory Oversight', Chapter 8 in M. A. Livermore and R. L. Revesz (eds.), 'The Globalization of Cost-Benefit Analysis in Environmental Policy', New York: Oxford University Press, pp. 123-141

- Wiener, J. and A. Alemanno (2010), 'Comparing regulatory oversight bodies across the Atlantic: The Office of Information and Regulatory Affairs in the US and the Impact Assessment Board in the EU', Chapter 19 in S.A. Rose-Ackerman and P.L. Lindseth (eds.), 'Comparative Administrative Law', Cheltenham: Edward Elgar, pp. 309-335

- Weingast, B. R. and M. J. Moran (1983), 'Bureaucratic Discretion or Congressional Control? Regulatory Policymaking by the Federal Trade Commission', Journal of Political Economy, 91(5), pp. 765-800

- Willems, B. and E. De Corte (2008), 'Market power mitigation by regulating contract portfolio risk', Energy Policy, 36(10), pp. 3787-3796

- Willman, P., C. David, D. Currie and M. Siner (2003), 'The evolution of regulatory relationships; regulatory institutions and firm behaviour in privatized industries', Industrial and Corporate Change, 12(1), pp. 69-89

- Wilson, C. M. and C. W. Price (2010), 'Do consumers switch to the best supplier?', Oxford Economic Papers, 62(4), pp. 647-668

- Winston, C. (1998), 'US industry adjustment to economic deregulation', Journal of Economic Perspectives, 12(3), pp. 89-110

- Wolak, F. A. (2006), 'Residential Customer Response to Real-Time Pricing: The Anaheim Critical Peak Pricing Experiment.', Center for the Study of Energy Markets Working Paper 151, Available at: http://escholarship.org/uc/item/3td3n1x1

- Wolak, F. A. (2011a), 'Do residential customers respond to hourly prices? Evidence from a dynamic pricing experiment', American Economic Review, 101(3), pp. 83-87

- Wolak, F. A. (2011b), 'Managing Demand-Side Economic and Political Constraints on Electricity Industry Re-structuring Processes', RSCAS Working Papers No 2011/61, Available at: http://cadmus.eui.eu/bitstream/handle/1814/19496/RSCAS_2011_61.pdf?sequence=1 
- Wolak, F. A. (2011c). 'An experimental comparison of critical peak and hourly pricing: the powerCentsDC program', Working Paper

- Wolinsky, A. (2002), 'Eliciting information from multiple experts', Games and Economic Behavior, 41(1), pp. 141-160

- Xavier, P. and D. Ypsilanti (2010), 'Behavioral economics and telecommunications policy', Chapter 4 in A. Gentzoglanis and A. Henten (eds.) 'Regulation and the Evolution of the Global Telecommunications Industry', Cheltenham: Edward Elgar, pp. 83-108

- Yarrow, G. (1989), 'Privatization and economic performance in Britain' Carnegie-Rochester Conference Series on Public Policy, 31, pp. 303-344

- Yarrow, G. (1991), 'Vertical supply arrangements: issues and applications in the energy industries', Oxford Review of Economic Policy, 7(2), pp. 35-53

- Yarrow, G. (1995), 'Airline deregulation and privatisation in the UK', The Keizai Bunseki, 143, pp. 49-83

- Yarrow, G. (1999), 'A theory of privatization, or why bureaucrats are still in business', World Development, 27(1), pp. 157-168

- Yarrow, G., C. Decker and T. Keyworth (2008), 'Report on the impact of maintaining price regulation', Working Paper, Regulatory Policy Institute, Oxford

- Yesilkagit, K. (2011), 'Institutional compliance, European networks of regulation and the bureaucratic autonomy of national regulatory authorities', Journal of European Public Policy, 18(7), pp. 962-979

- Yeung, K. (2010), 'The Regulatory State', Chapter 4 in R. Baldwin, M. Cave and M. Lodge (eds.), 'The Oxford Handbook of Regulation Oxford: Oxford University Press, pp. 64-83

- Zelner, B. A., W. J. Henisz and G.L.F. Holburn (2009), 'Contentious implementation and retrenchment in neoliberal policy reform: The global electric power industry, 1989-2001', Administrative Science Quarterly, 54(3), pp. 379-412

- Zhang, Y., D. Parker and C. Kirkpatrick (2005), 'Competition, regulation and privatisation of electricity generation in developing countries: does the sequencing of the reforms matter?', Quarterly Review of Economics and Finance, 45(2-3), pp. 358-379

- Zingales, L. (2013), 'Preventing Economists' Capture', Chapter 6 in D. Carpenter and D. Moss (eds.), 'Preventing Regulatory Capture: Special Interest Influence and How To Limit It', New York: Cambridge University Press, pp. 124-151 